
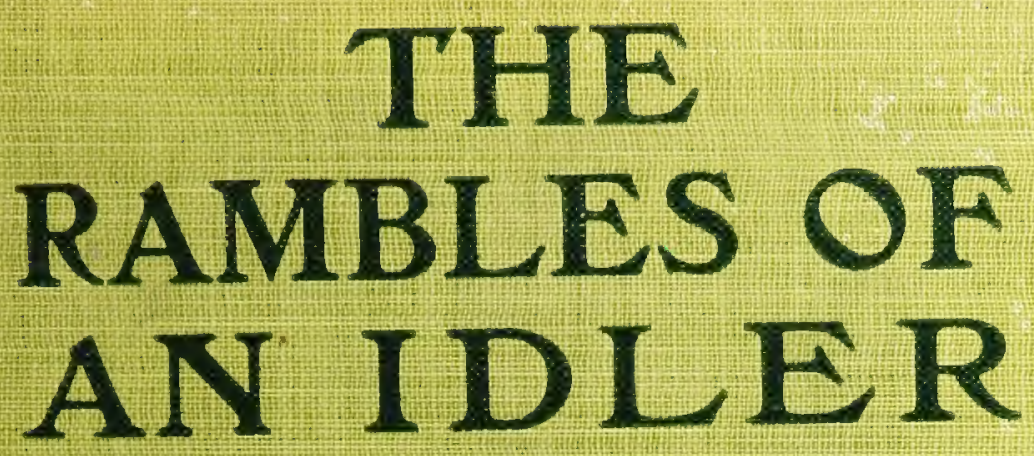

\title{
CHARLES C. ABBOTT
}




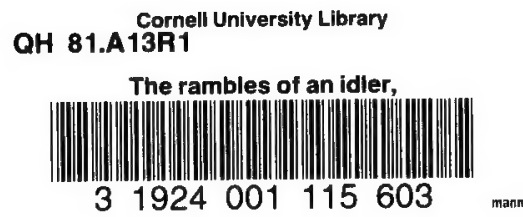




\section{THE RAMBLES OF AN IDLER}

BY

CHARLES CONRAD ABBOTT, M. D., Author of "Days Out of Doors," "Outings at odd Times," etc.

Happy is he who remains a free lance in the world of facts.

He alone shall never want for thoughts.

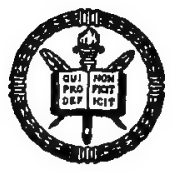

PHILADELPHIA AND LONDON

GEORGE W. JACOBS \& COMPANY PUBLISHERS 


\section{Copyright, 1906, by \\ Grorge W. Jacobs \& Company, \\ Published June, Igo6.}

All Rights Reserved

Printed in U. S. A. 


\section{To}

\section{JUNIUS S. MORGAN}

AN AUTUMN WALK AFIELD, SOME YEARS AGO, MADE MEMORABLE BY YOU, AND WHICH LED TO MANY A LONGER WALK SINCE, MAKES FIT THAT, WITH YOUR PERMISSION, I DEDICATE TO YOU THESE DESULTORY RECORDS OF DAYS OUT OF DOORS, IN WHICH YOU HAVE TAKEN SO LIVELY AN INTEREST.

C. C. A. 


\section{Cornell University Library}

The original of this book is in the Cornell University Library.

There are no known copyright restrictions in the United States on the use of the text. 


\section{PREFACE:}

Speak the word "idleness" as harshly as you may, still it falls softly on the ear. Whisper "work" in your most dulcet tones and still it is harsh.

Idleness has its merit, therefore, but what of its significance? Its persistently claimed purport has been preached down so vigorously, that he is over-bold who would invite it to look up. It is true, nevertheless, that the average man labors that he may not labor. He looks to an earned idleness as his just reward. Why, indeed, should he not?

It is a favorite, but not demonstrable doctrine, that idleness once attained, mischief follows. If so, one might well ask the value, to its possessor, of an average life. Then, too, why does the poet hold that it is

Sweetest to dream, on easeful earth reclined,

Far in some forest's ancient idleness,

Under the shadow of its bossy boles,

Beyond the world's pursuit and Care's aceess.

And hear the wild feet of the elfin wind,

Dancing and prancing in mad eaprioles. 


\section{The Rambles of an Idler}

I venture to speak, in the following pages, of that idleness which leads us not merely to touch the hem of Nature's garment, but to clasp.her hand.

Eagerness may make one clumsy in such an attempt and, though he succeeds to a personal satisfaction, yet, lacking grace, his "impressions" had better fall back into the ranks of the unrecorded. Good advice this, but no one thinks of its personal application.

To wander as Nature's guest, has been my aim; alike in sunshine and in shadow, under the bright blue sky and when the storm-king asserted his ugly strength; gathering a harvest that does not diminish, however frequent our call upon its store.

Such harvest contradicts, it seems to me, the assertion often heard,

Great the effort, great the gains;

Idleness and naught remains.

Argument savors of work and I eschew it.

The days came, the days passed by, and be it for good or evil, I am yet able and very glad

Under the shade of melancholy boughs,

[To] lose and negleet the ereeping hours of time; 


\section{Preface}

and have no wish to look on better days, nor regret that $I$ have

Idled all my life away;

Played with work and worked with play!

I am often very much amused at some of the land-owners within the range of my rambles. I keep so far within bounds in all I do or say that I escape being regarded as a trespasser, but sometimes, judging from the impatient countenances of those I meet, I am looked upon as a fool.

The best of what some land-holders have never actually becomes their own. They take nominal possession and $I$ the actual; and when in unguarded moments my enthusiasm leads to audible expression, they gape and wonder at what they hear, and, as I say, set me down for a fool.

Let me enumerate: There is the beauty of a particular tree - the owner never saw the tree, perhaps; there is the mottled carpet where grass and moss alternate, and in season dainty flowers brighten the whole; there are the best points from which to view a sunset-how many only know that the sun goes down; and vii 


\section{The Rambles of an Idler}

there is the charm of a spot where the Indians had gathered and left imperishable traces of their one-time sojourn. I fill my pockets with many pretty pieces and march off, head up, the very lord of that particular speck on the broad map of creation. The farmer-owner has his pork and corn, but the harvest I have gathered is beyond him. I do not ask permission; why should I? His cupidity might be aroused and I denied entrance. So I go on my way rejoicing as he goes on his. His the worry and the work to lift the mortgage; mine the joy and the wholesome exercise to lift the relics. Who is the true owner of the land?

I know a brook that never fails to sing, its home a cliff-side shaded by old trees. Ribboned clay and glistering white sand make the walls and floor of this enchanting spot, and many a bird tarries long to sound its praises. The winter sunshine lingers lovingly and the frost but ornaments with crystals the twigs of spicewood and weights the unwilted ferns with gems. He who takes a mid-winter walk finds it an ideal inn. It is always full of good cheer. As an acre of ground it is my neighbor's property, but I have been its owner for many a long 


\section{Preface}

year. To be sure, he can pitch its beauty into a cart and carry it off, and would, doubtless, to make a dollar; but I carry treasure from it every time I chance there and he is none the poorer. I hope his legal and my ideal interests will never conflict.

He who walks to best advantage goes to the country empty-handed and so is free to bring back what he finds. To reverse this order is often walking to no purpose. To take one's town-troubles and town-interests into the fields to give them an airing, may do them good, but not yourself. Go as empty-handed and emptyheaded as you can. Unload all your cares in the house or in the street and when the open country is reached, you are in a truly receptive frame of mind. You have an appetite for novel impressions. The natural replaces the artificial so completely that, on returning, you scarcely know yourself, and find it hard to explain why so many really petty annoyances incident to town-life vex one so mightily.

It is a comfort to know that always within reach is some nook or corner in Nature's realm where one's real self can come to the surface; so, when the chickadee warbles, Hear me! you 
can whistle back to it, in the same earnest and fraternal spirit. Thus minded, the legal niceties of land-ownership will not intrude. You go about as Nature's guest and forget that any bull-dog may be on the look-out to defend its owner"s sordid rights. Man mars not makes the landscape. The chances are, these crowded latter days, that he is Nature's enemy, not her friend, and certainly as he has waxed mighty in intellect, Nature holds him at arm's length with all her power. A product of her forces but a rebellious one that she never forgives and kills when she can. There should be no warfare, it is true, but there is, and in the end she conquers. As dust she takes him up again and fashions something else or a new man; but if the latter, always with the hope that he may prove more of a success, seen from her point of view.

But never mind man, alive or dead; let us hear what Nature has to say. The main purpose of an outing is to listen, to hear accurately, to heed implicitly. It is ill-bred to shout in her ears. She knows our needs, our limitations. She will point them out in time, and he who has been so far favored is fit for any company. 


\section{Preface}

By permission kindly granted by the publishers, the "Fresh" on the Ma'sh," "I go a-Maying," "An Alpine Morning"' and "Eden: Past and Present," originally appearing in "Lippincott's Magazine," are here reproduced.

C. C. A.

Three Beeches: Trenton, N.J. 



\section{CONTENTS}

Chap. Page

I. IMPRESSIONS • • • • . . • . . . 1

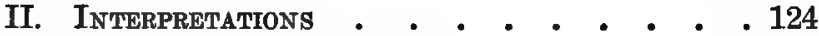

III. Peripatetic Mmitations . . . . . . . 152

IV. Candor . . . . . . . . . . . . 192

V. The Excellence of Misfortune . . . . 204

VI. UNDER THE OAKS AND ElSEWHeRe . • . . 216

VII. From Pillar to Post . . . . . . 254

INDEX . . . . . . . . . . . 301 
Lord of Myself! No cares demand My time to troubling labor given; With day-dreams I go hand in hand; How oft for such an hour striven! Now mine to have, to hold; to be From earking eare, an hour free.

Slave of stern eireumstance no more, The purling brook a welcome ealls. Mine now the green wood to explore, To rest where sunlight softly falls, Where shadows sport the oaks between, Where Nature's hand alone is seen.

Mine to converse with happy bird, To listen, while its song uplifts;

To outlook, trouble has not blurred Thither my soul full eager drifts.

Lord of Myself! Such hour as this, Incarnate grows man's fabled bliss. 


\section{The Rambles of an Idler}

\section{CHAPTER ONE}

IMPRESSIONS

It is well to make sure of every passing thought. Later, it may prove the text of an effective sermon. The same is true of much that is suddenly recollected. Why the past returns, let the psychologist determine. If we can gather figs from such thistles, it is all that need concern the most of us.

I have before me a fragment of a diary, dated "Fourth day, Oct. 1, 1800." Here is inconsistency at the very outset. The language of the Quaker and the man of the world in one sentence. Does it mean my great-grandfather was a Friend on First Day and otherwise, through the week?

He starts to drive from "Abbott's Landing", 


\section{The Rambles of an Idler}

on Crosswicks Creek to Maurice River, a long journey through "the Pines." $\mathrm{He}$ does not record a single interesting fact. Who cares if the wagon did break down? How very differently I would have kept that record of a long ride! Would I? The environment of the current moment is the impelling force, and what has happened, happened necessarily. To go counter to the normal inclination is to fail. My great-grandfather was concerned with his own affairs and how was he to know he would have an inquisitive great-grandson?

This sounds more reasonable than it really is. There are people to come as well as people now who are going and we who still live are not sufficiently inclined to leave some permanent traces of ourselves behind us. Did we do so, truth would more highly color history. There is now too much inference based upon a few facts. I can fancy my great-grandfather on his way to Maurice River, but how much better, could I see him, thanks to vivid description. But, do not find fault with our forbears and be indifferent to posterity. We are too prone to think what we have done or seen or heard is of no importance, and so to record it is 


\section{Impressions}

useless. It is always the other man who ought to do this; - and the other man thinks the same. He is not more capable as you suppose. A universal wrong impression goes the rounds and the result is ignorance where useful knowledge might have been. Did we know the past more correctly, we could the better enjoy the present and take care of the future.

There lie two ways to every end,

A better and a worse;

and the better one is not to leave too much to the imaginations of those who will follow us.

Could I, from body free, in shadow lurk, Methinks a useful lesson I could learn;

Seeing my better self in love with work, From idle day-dreams, in disgust, would turn;

Toiling in earnest, such a picture make,

Would love my task for the appearance' sake.

Just as every old town has one or more old streets, so there are peculiarly old places that escape for a long time the disastrous effects of the march of improvement. In the old town nearest by, there is a business centre - Inferno's gate, and a residential section - a long 
way off from Paradise regained. The former is too like rotten fruit; the latter too like that which is green. Neither is to my liking, so I pass them by. Good, matured fruit, such as delights me, I found in a back street, an old thoroughfare but little travelled now. Too far from business, thinks the merchant and the land is not sought for warehouses. Nobody that is anybody lives here, comments the newly-married woman and she passes it by. Happy side street! Fortunate, truly, in the neglect shown it. It rejoices, in its calm, dignified way, in an old house; one with oak beams and honest walls, with a fire-place instead of a stove-pipe hole; a house with an odor of antiquity, which is vastly preferable to the odor of sanctity; and here lives David Pickup, dealer in Old Furniture.

It was by mere chance that I passed that way, a happy impulse due to the fact that here I had played full fifty years ago. The old occupant of the house has long been gone. David is a comparatively new comer. I was struck by the name stenciled on the little sign above the door. Such a name! and that too coupled with such a business. I was so far interested that I made 


\section{Impressions}

excuse to enter the little shop and this initial visit has led to many since.

My trips to town now have a rational purpose. I go directly to Pickup's, that I may get deeper into the country. Here more than any other place that I know of, centre the relics of more than one century. The shop is the Paradise of old tables, sideboards, desks and chairs. Here, their wrongs are righted at last and they are given new leases of life as rewards of merit.

Banished for fancied uselessness or ill-looks - "out of style" as silliness declares-to garret or cellar, or put to plain uses that tried all its strength, this uncomplaining furniture is recognized at last at its original and still true value and a wiser owner restores it to its place of honor.

David Pickup himself is old in all things save in years. He loves his work, and his knowledge of furniture, its history, method of manufacture, and materials used, is far more extensive than that of many writers on the subject. How like a professor before his class, would he pick up a piece of wood, dust it with his shirt sleeve and call attention to the beauty of the grain. "There is mahogany worth having"; 


\section{The Rambles of an Idler}

"here is real bird's-eye maple"; or "cherry trees are not old enough now to have wood like this, red as blood;" or "here's cedar that is cedar, not faded yet and sweet smelling." More or less of all this would he say in a most impressive manner; and less often, he would lay down his saw or plane and seating himself in a chair I have long coveted, throw his arms back to support his head and exclaim with great animation,

"Wood, like wine, improves with age, if properly cared for and what.strange stories these old things could tell, desk or chair, that is, if they could only-," then glancing at the little clock, he would start up, saying, "Phew! I've no time to waste."

David Pickup is not an extraordinary man, but his remarks are always timely and that is being next door to a philosopher. $\mathrm{He}$ is not original, but then, the world has not had a brand new set of ideas in a thousand years, and as far back as that plagiarism was not uncommon. David makes excellent use of the old set phrases; better use than does the crowd as you meet it. At least, he never speaks an unnecessary word and when my visit ends, I find I can 


\section{Impressions}

carry home his conversation as easily as I can recall, if I desire, the aromatic atmosphere of his shop. These visits are, indeed, like going back and seeing what once was, and was for the better too, instead of hearing or reading history. To be your own great-grandfather for an hour and face solid wood instead of veneer, is an experience worth the trouble that it costs.

I was not the only casual visitor. More than one old man of the neighborhood had found David's shop, and when, one dreary November afternoon, I heard mention of the recent high water in the Assunpink Creek, I recalled and recounted, as best I could, the story I had heard of a flood of long ago, as told at the crossroad's corner near my home.

Along the north wall of the smithy ran a low seat giving comfortable room to four people. It was far enough away to avoid the sparks from the anvil and, having a sunny, southern outlook, was the chosen spot where four old men of the village were wont to gather every bright winter day. Job Stillereep was the dean of this little faculty, in whose keeping were the traditions of the neighborhood,-a long-settled 


\section{The Rambles of an Idler}

one, yet never having sufficient vigor to outgrow the primitive conditions of its Colonial days.

The winter was drawing to a close, and the current topic of all was the signs of spring. As it usually happened, in whatever was discussed, Job was not in agreement with his hearers. Whatever they suggested as surely indicative of the season's end he vigorously criticised, not that there was no basis for such a view, but because he had not hit upon it in advance of others. To-day it was another matter altogether, and one where agreement might be looked for, but Job was not even now in an acquiescent mood.

'I never know'd a higher fresh' on the ma'sh than this last one," remarked Benjamin Goodwheat, 'an' it beats all creation where sech a lot o' water comes from."

"Then you didn't see the fresh' o' '41," replied Job. "I was nineteen that winter, and what with duckin' and mus'-rattin', didn't do much loafin'. The spring afore I follered fishin' above Perriwig Bar, but ol' man Biles was too contrary when the shad didn't run well, and sort o' laid it on us boys for not workin' the net right. I kicked an' we had it hot, an' 


\section{Impressions}

a 'ter a tongue-lashin' he gave me I got out. It wasn't what I wanted. His da'ter Nance drew me more'n the pay I was gettin' an' he know'd it; so he gave me to understand I needn't keep loafin' round. But I did see Nance more'n once, an' she didn't side with the ol' man. I kep' up heart an' worked on the farms 'round till fall came an' saved every penny I got. 'Long late in the summer I laid 'em out for a good gun an' fixin's an' turned to huntin'. Hides was a good price and Sammy Quicksall took all the ducks I shot at a fair figger. Things went on purty well till about Christmas, when I got restless-like for Nance and couldn't foller anythin' fur thinkin' o' her. You know how lads is when they get this way real bad, and that was me fur sure.

"I tho't it over, and says I, 'I'll go see the ol' man and make up if I can.' I went over from Duck Island to his house, but he seen me a-comin' and comes out, warnin'-like, and orders me off. He 'lowed he'd all his hands engaged. I said I was sorry, but up and square told him that wasn't what I came fur, but to keep steady comp'ny with Nance. Says I, 'I've a bit laid up, and can work steady as a farm 


\section{The Rambles of an Idler}

hand all summer and foller gunnin' and trappin' fall and winter.' He wouldn't listen. I kep' a-jawin' and all the time edgin' towards the house. I seen Nance standin' in the door, lookin' sort o' smilin' like, and that kep' up my courage more'n the ol' man's gab kep' me down. "Gettin' near enough, I says, 'Who do you favor, Nance?'

"She up and says, 'You, Job, 'cause you're fair and square and Daddy's no reason to go ag'in' you.'

"You never saw a madder man than ol' man Biles.

" 'I ain't goin' ag'in' you, Daddy,' says Nance, 'but I can't help my favorin' Job. You know he's as good as any young feller 'round, and nobody's got nothin' ag'in' him.'

"I wanted to up and kiss the gal right there, but just held off a bit.

" 'Get out o' here!' hollers the ol' man to me. 'Go in the house!' he hollers to Nance.

" 'Not much," says I. 'I'm in the public road jus' at present and committin' no breach $o^{\text {' the }}$ peace. But by the eternal racket,' says I, 'if you're rough with Nance in my hearin', either with your hand or your tongue, there'll be 


\section{Impressions}

trouble in the road or off o' it, as it happens where you be.'

" 'I'll get a warrant out fur ye fur threatenin',' says the ol' man.

"Now, warrants is a nuisance. They're apt to interfere with your plans, so I sings out, 'Good-by, Nance!' and got out. She waves a bit o' ribbon and then said somethin' I didn't catch, but I 'lowed it was all sweety words, and so went away cheerful.

"It took me a couple o' weeks to get settled like. I couldn't plan nothin', seein' Nance was out 0 ' reach. I'd a notion fur a house on the Island, but Nance might like one on the Manor shore. I got all upsot, and says I, 'I'll see Nance, spite o' the ol' man.'

"That very day it started in a-rainin'. The wind got 'round to the s'uth'ard and snow and ice melted all in no time. Thinks I, 'There'll be a fresh'.' Then I tho't o' Nance. The ol' man's house was too close to the river shore for safety, anyhow. More'n once the water had lapped over the front step, and in '39 it was on the first floor. There was no crossin' the river in a boat, so I went up to the bridge and walked down on the Manor side. The water kep' 
a-comin' up and up, and I know'd trouble was a-brewin' for the folks in the low lands. Talk about streaks o' luck! 'Fore I reached Biles's I seen a strange boat with oars in it comin" down stream lodged in some bresh. I know'd it was from up the river, so I'd a right to take possession, an' you bet, I did. 'If,' says I, 'if the ol' man's ugly, I'm here to watch out for' Nance, if he won't have 'sistance from me.' I had to wade to get the boat and was wet through, then and there, an' shakin' with cold, but that wasn't nothin'. 'It was all for Nance,' says I, and I work'd 'long the edge of the water like till I got to the big net-frame, and then I hollered.

"' 'Who be ye?' hollered the ol' man back.

"' 'Me, Job,' says I, and then Nance show'd at the winder. She was teary-like 'round the eyes, it sort o' seemed to me, tho', course, I couldn't see her real plain that far away.

" 'Goin' to stay in there?' I hollered, not goin' up to the house.

" 'You can give your help where it's wanted,' hollered the ol' man, and slammed the door.

"That there settled it for me. ' $\mathrm{Ol}$ ' man or no ol' man, Nance ain't goin' to be drowned, if 


\section{Impressions}

he means to be,' says I, and rowed up as near as I could get.

" 'Don't you come no furder,' hollers the ol' man.

"I didn't holler back, but pulls ashore and goes 'round the blind side 0 ' the house. Nance know'd if she didn't a-see me, and luck had it ag'in, for the ol' man kep' his eye on the river. When I got back o' the house I made a motion to come out, and Nance. opened a little winder and waved her hand. Wake snakes! but my heart giv' a thump, and I know'd then I was in for biziness. I crep' up along the garden fence and got real close. She saw and said, softlylike, she couldn't clim' thro', an' Daddy would ketch her if she opened the back door.

“' 'Ketch or no ketch,' says I, 'an' I'll tend to Daddy,' says I, and fust I know'd, she was out o' doors and I grabb'd her. 'Fore the ol' man saw she was in the boat, and thar he came a-hollerin'. You never saw a madder man than the ol' man was. He hollered, 'Clome back!' but she knew it was for her life she was runnin', an' we put out into the river.

"It was fool-work, sure enough, but I was only a fool of a chunk then, and tho't only o' 


\section{The Rambles of an Idler}

Nance and nothin' o' nothin' else. A young feller in love, you know, ain't apt to be overburdened with common sense. Fust, I know'd we was in swifter water than I could tackle. The way we rush'd 'long was a caution, an' all there was to do was to keep out $o^{\prime}$ the way 0 ' logs and bresh-wood; but no use, a tree came quicker'n we were goin', an' we got fetched up in the branches. The tree took a roll like in a minute, and sort o' lifted the boat out o' the water, an' there we sat, ridin' in a way that was goin' faster'n pleasant. If the tree took another roll, we were goners, that was plain, an' I up an' says so.

“' 'Job,' says Nance, 'if it's God's will, so be it. If we can't live together, we can die to= gether, an' that's better'n livin' apart.'

"Didn't I feel queer-like! That woman sittin' there like one in a pictur jus' made me grit me teeth, grip me oars, an' wait. I kep' one eye on the water and one on her, and 'fore I know'd it the tree giv' a lurch, an' the boat, 'stead o' upsettin', was free ag'in. Didn't I pull for the Jersey shore then, an' Nance didn't look like herself, but more'n ever like a pictur. It was gettin' dark like, and the Bordentown 


\section{Impressions}

lights begin to show out shiny. I pull'd till 'most my arms giv' out and then got into where it was easier rowin', but we was tangled up with rubbish in the mouth o' the creek an' there we stuck, movin' slowly' out into the ma'sh. Logs, trees, housel-goods, sech a mess, an' all there was to do was to drift. Nance got sort' o' shiverin' but said nothin', but I heard her teeth chatterin' and I took off my coat and put it over her.

"She was cryin' like too, but I says nothin". I seen a chance to get clear, I tho't , an' I pushed and poked with the oars and sort $o^{\prime}$ got out of the worst of it and a bit nearer the shore. Then I hollered. Folks had seen us. We was still out $0^{\prime}$ reach for a time, but gettin' nearer, and soon a feller flung a rope and, pullin' on it, we got near enough to step over logs and get ashore; but it wasn't easy. Nance was that weak she had to be held up like, and once down we went clean up to our necks. It was nip and tuck then, but a man got out to us and we carried Nance, a dead weight, to the shore at last. Women folks took her into the house, so they could look after her, and I give out for once. I was nigh about as near gone as Nance was, 
but a swig o' rum sort o' sot me up, an' that was the last swig ever passed my mouth."

"Passed it outside?" asked Benjamin, interrupting Job for the first time.

"No, inside, an' here I be, eighty-one an' what the minister calls a livin' monniment to lettin' rum alone.

"As I was sayin', I was over the wust of it an' sot by the stove to dry off. But I did more'n that. I fell asleep an' slep' an' slep' till it was way on in the nex' day. When I woke I was lyin' on a settee by the stove, an' the fust I said was, 'How's Nance?'

'The men 'round said nothin' an' a woman was a-cryin'. Says I, 'What is it? You're boun' to tell me.' But they says, 'Keep still, Job, an' don't let her hear you.'

' 'Says I, 'Then she's livin',' an' I sort o' fell asleep ag'in. But not for long. I heered a scream an' was on my pins in a second. I made for the room she was in, and sech a sight! She was white as a snowbank an' wild-like 'round the eyes. Says I, 'Nance, be ye right ag'in?'

"'She only says, 'Job,' and fell right back'ard. Then I got settled like an' felt I was Job Stillcreep, sound and hearty. I never left Nance 
more'n a minute or two all that day, an' the Doctor said she was mendin', an' she did. Seein' me set her right, for she'd a notion I was drowned. It didn't take long to come 'round, an' we both were up an' ready to be doin', only she was baby-like and took hold $0^{\prime}$ cheers and tables sort o' when she moved around. We was in good hands, an' says I, 'Nance, now you're 'round ag'in, I'll go look up your Daddy.'

"She gives a jump at that an' up an' give me a smack I can hear the noise of yit. The women 'round sort o' laughed, an' Nance got red an' says, 'He's airnt it, if ever a man did.'

" 'Them words is worth goin' it all over ag'in for', says I, an' I went out with the fellers to see the sights. The water was down a good bit, an' I borrow'd a skiff an' was for goin' over to the ol' man's, but they said it was no use. His house was gone down the river an' no one had heard o' him. 'Keep it from Nance,' says I, an' I went just the same. It was a tough pull, but I got there. The ol' man was a-walkin' up and down where the house used to be, an' when he seen me, about a hundred yards off he stopped a bit and then up 


\section{The Rambles of an Idler}

with a gun an' levelled it. I dropped into the boat as he blazed away, an' the shot rattled 'round but didn't hit me. I let the boat drift, peepin' over the gunnel. He loaded ag'in and fired, but I was too far off, an' then I seen two men a-runnin' an' they swung their arms 'round an' held him an' drug him away. I went back, sort o' worried-like, an' up an' told Nance all about it.

"Says she, 'We'll go over there together,' says she, an' sech a look in her eyes I never seen afore. She wouldn't take no from no one.

" 'Are you a-feared, Job?' says she.

"Says I, 'No,' an' we went. There was nobody 'bout when we got there, an' we didn't know rightly jus' where to go, but soon we saw the ol' man a-comin'. He'd slipped away from the folks as was a-keepin' an eye on him, an' Nance and me stood there together. He was gone clean daft. There was no look o' sense in his eyes, an' he wouldn't say nothin'.

“' 'Daddy,' says Nance, 'don't you know me?'

" 'No,' says he, and then he looked wild at me, an' Nance begin a-cryin' and callin', 'Daddy', 'Daddy.' 


\section{Impressions}

'I hollered 'Help,' half-fearin' trouble, and the men came a'ter the ol' man a-runnin'.

"Says I, "Go for the minister if he be in reachin',' an' they look'd at me, wonderin', but one of 'em went off. We four what was left stood there a-waitin', an' it seemed as if the day'd be gone 'fore t'other one come back, but he show'd up as the sun was a-settin' an' the minister with him.

" 'Be it you're willin', Nance and me'll get married,' says I. 'It's best for the ol' man an' us too, I'm thinkin'.'

" 'Really,' says the minister, 'but this is most unusual, and really I must-'

"I cut him short. "This is no place for preachin', nor time neither. It's marryin "I'm in for, an' ask Nance if she's agreed to it.'

“'The minister looked sort o' kerflummixt, but says he, stammerin' like, 'Miss Biles, is it your wish, under these remark'ble circumstances?' "'She up an' says 'Yes,' and lookin' at her daddy says, 'Daddy, don't you say so?'

"The ol' man didn't say nothin', but kep' a-lookin' sort o' wild like.

“ 'I'll take care of 'em both,' says I, 'an' it might as well be here as anywhere, an' the 


\section{The Rambles of an Idler}

sooner the better.' The long an' short of it is, the minister married me and Nance, with them two men to witness it, an' he give us his blessin' an' I giv' him a dollar. Then we stood there a minute, feelin' foolish like, I s'pose, not knowin' what to say, when the ol' man holler'd, nat'ral like, 'Nance, don't leave me!'

"Nance sprung on his neck like a cat on a sparrer an' most knocked him over.

"The light come back in the ol' man's eyes an' he shook like a leaf in the winter-time. He held out his hand an' I took it, an' then, somehow, everything look'd brighter, an' Nance cried an' laughed till I tho't she would go crazy. The ol' man cross'd the river with us an' we went to where me an' Nance had been stayin".

"We soon got to work ag'in where the ol' man's house had stood, an' put up a bigger an' better one, an' did well that spring a-fishin', and then I settled down an' staid there till two year ago, when Nance 'crossed over,' as the minister said at the funeral, an' I'll soon foller an' hope I'll see her on t'other side. That was a fresh' on the ma'sh, in ' 41 , sech as I never seen afore nor since." 


\section{Impressions}

Walking has ever been a favorite theme with the essayist, and many a philosopher, too, has given it such attention that in these days when originality seems exhausted and literary decadence to have taken firm hold of the intellectual world, whoever refers to the subject should be careful that what he may say as his very own thought proves not to be a crippled echo of ancient eloquence. His only excuse will be that an echo may have value. If we cry out and the echo is heard, we may get a reply as promptly as if the original utterance fell upon the ear. Whether or not it proves an oft-told tale, I would speak of walking.

The peripatetic can point to Aristotle and no one can refer to a higher authority for aught he does; and the peripatetic who has Nature for companion is likely to prove the equal, in life's tug of war, of any automobile citizen who believes that haste is the chief end of man. Because we associate life with motion and absence of it with death, the former is not necessarily in proportion to activity. Crystals are now said to be alive, yet we cannot see them move. Comets, on the other hand, are dead, yet for- 


\section{The Rambles of an Idler}

ever in motion. As in so much that concerns mankind, there is a happy medium. It can be set down as a rule that the walking man thinks, and as he thinks, so does he walk. This is Nature's law, not man's. The contemplative, the angry and the frightened man are readily distinguished by their walk.

The fact that the definition of "walking," as set forth in the various dictionaries, has to do with locomotion, does not set aside the far more important fact that we need not walk a great distance to become far-traveled. It all depends on what our interest centers. A wayside pool of insignificant dimensions might keep one stirring for a dozen years. Nature deals in riddles as well as in plain print.

But, is this walking?

It is breathing the fresh air. It is having moss or grass to tread upon. It is standing more than sitting. It is motion more than rest. It is the best of all the good things Nature offers. You may call it not walking, but, if so, it is a splendid substitute and the happy result is that we gradually cease to be strangers in a strange land; for until we know the world in which we live, we are simply tolerated guests. 


\section{Impressions}

When knowledge replaces ignorance we are less guests and more companions. If we cultivated earth-knowledge as we do artificiality, and spent with weeds and rocks the time that is given to vain speculation concerning the unknowable, Dame Nature and "Homo sapiens" would be better friends. Man has been on the earth for many thousands of years, but has not yet reached to the years of discretion concerning this planet.

When we think of the pebble that obstructs our step as but an obstacle to easy going, and toss it contemptuously aside, we are not walking to good purposes; but if the pebble commands our attention, if we see it as a fragment of a great bed of rock, if we see that it has been rounded by water action, rolling for ages in the bed of a stream, then we are walking, and the mere movement of the lower limbs is the least part of it. Walking calls for our head as well as our heels.

I remember that when a child and sent upon an errand, I was told not to loiter. But I did. I learned to loiter as I learned to walk, and rejoice now that parental instruction was not fol- 


\section{The Rambles of an Idler}

lowed to the letter. I remember finding, half a century ago, a great cluster of butterflies on a little bush, and I stayed and played with them until it began to grow dark. The errand was quite forgotten, and of course there was a grand commotion at home, but what of it? I was only learning to walk. I remember, later, walking farther and farther into a dense swamp until the sun was near to setting and then finding myself out of it, but in strange fields. I had wandered wherever interest pointed and had no thought of fatigue or fear, and was fresher when found than were those who were searching for me. Such methods of learning to walk may be open to objections, but no others are as effective. If eyes and ears do not play their part, the little the legs do goes for nothing.

Walking calls also for the exercise of memory. The earlier walk recalled will throw light on the later one. The inexplicable of yesterday, seen under disadvantage, is plain to-day when the conditions are more favorable. The unfamiliar chirp that we heard may be a more elaborate song the day following and what was then a vexing mystery is now a pleasing fact. 


\section{Impressions}

The bird in full song and in full view, we recognize when as a chirping imp in the shadows it only piqued our curiosity. We are never sure of some small plants until we see them in bloom, and the day of their flowering follows that of being in leaf. We always need two walks and often more to make sure of any fact. We need to walk day after day to learn the preordained method of Nature and the earlier outings must not be blanks to us when the climax of the season is finally reached.

We look for exertion to be rewarded and all know that fortune earned is better appreciated than wealth without effort. The best inheritance is a desire to succeed. The silver spoon that accompanies a birth may overweigh the infant. The walk that is most successful is that which better equips us for another like undertaking. Walks should be a series of exertions, with a reward awaiting them at their close. The fact takes hold when we face it, but not always when we merely hear or read about it. We may read all the natural histories ever written, and then, going out of doors, continuously be asking ourselves, What is this that I see? 


\section{The Rambles of an Idler}

And this going out of doors must be as Nature intended, on foot. We must walk, not ride, across the plain and wade the brooks and thread the tangled wildwood that lie between us and the mountain. We are then equipped to realize the whole purport of the rising ground, and when at last we reach its base we must proceed step by step, yet climbing ever higher and higher, and by this means secure that alertness of all our senses which is called for when, at the summit, the world lies spread before us, in order to get not only an intelligent but a comprehensive view of it.

This I conceive to be walking in its entirety, and is far removed from mere exercising: of ambulatory muscles. The latter may be a remedy for rheumatism, but never for ignorance. The advocate of muscular pedestrianism might with perfect consistency rest his head on the ground and let his heels wave in the air as the most important part of him.

To admit the logic of the "unco guid," to be wool-gathering, rather than forever occupied with the stern facts of life, is to go astray, but $I$ contend it is a sin worth sinning. It is but a brief and blameless existence in an ideal 


\section{Impressions}

world, one where fruit is all sweet, flowers all fair, the weather a succession of Maydays, where all wrong is righted and pain unknown. All this, at least, I find is the substantial unsubstantiality of a winter-day walk and woolgathering.

It is significant that we can speak of walking in winter in a confident manner. When the south wind tempers the icy breath of the north, I go a-walking and a-wool-gathering by the way. I have a clear vision of what was replacing everything which is. Every blot upon the landscape fades. A bird's song now is the reviving echo of dead music. When the earth was younger, I fancy it must have been fairer. It matters nothing that this may be false. What I now see is very real, though it does not exist. One gets outside of himself when wool-gathering and is not to be measured by a commonplace standard.

This winter day: there never was another more perfect. I have the crested tit for my authority. Its song may not have changed since June, but it sings now for its own entertainment and not for its mate. Perhaps it, too, is wool-gathering and is now not the master, but 


\section{The Rambles of an Idler}

the slave, of thought. Surely, very suggestive of meditation is its song to-day. Howsoever this may be, its music moves me. I am as responsive as the vane to the passing breeze. A few, clear, fife-like notes escape the tangle of a vine-clad nook and the keen air trembles as if the wind had whispered. They bring to mind the magio of May, of spring-tide life and all that filled life's goblet to the brim. An empty glass now and orerturned, yet who, when it was held aloft, thought he could drain it? Youth laughs at Father Time.

Now, almost mute the sparrows in the field, but still I hear their fragments of a song. Wherein can lie the pleasure of a vain regret? Vain to review the past, as they seem doing. Vain to shout in ears that do not hear. I smile now to think of that perfect world which that untaught youth beheld; but the crested tit, so earnestly it sings, seems not to mourn over joys it has tasted. It rejoices in the recollection thereof; so it may be better, after all, to be wool-gathering than overly serious. It is well occasionally to play the fool. Wisdom should not be allowed to drain the under-current of 


\section{Impressions}

humor. Remain flexible enough to laugh. Knowledge should not become a dead weight.

The fitful sunshine seeks the whistling bird. The glint of sunbeams stirs its responsive pulse and a yet livelier song comes up the glen. I, too, am stirred. A sun-lit summer moment has returned. The woods are lovelier than they were anon, the water sparkles where it has been dull. The bird's song is a voice silent long years-a cloud passes, the tit murmurs but a single note. The past is past, indeed the present faces me as a grim fact. Life plays many a prank upon our peace of mind.

The birds are not always with us in winter and peopling such vacuous days is a dangerous pastime. We cannot choose our companions and how often more the unwelcome than the welcome guests. Regret, the aftermath of illborn thought, fills the vast charnel-house of days gone by. The breeze that stirs the few, dry, rotting leaves remaining tells us that summer has been, but are we the wiser? What might we not have learned: how little knowledge has been added to our store. We recall the pricking of the thorns, with all the attendant pain and sorrow, but have no roses to show. 


\section{The Rambles of an Idler}

Ever the old story, more reason to lament than to exult.

But, preaching to the winds! Either I hear winter's little yellow tree-toad or Time is ruminating in a muttering way. One or the other, and I, too, "chew the cud of sweet and bitter fancy," for these are the perfected days of winter and both meditation and exertion are called for. Labor is set to music and we can both sing its praises and practice its precepts. I am standing now on the sunny side of an old tree wondering what next to do.

Old trees-do they wool-gather?

Three or more hundred years ago this wayside chestnut was a trail-side tree. Does it think now of those who passed when it wore a greener crown and does it deign to notice the toiling, overanxious crowd that daily passes? As all that is left of a one-time forest, the tree alone concerns me. Why? To-day, like the poor, we have always with us, but it is not always that we have the past. Here lies the charm of a wool-gathering stroll. This tercentenarian chestnut has a word only for those who look backward; and the trail, the Indian, 


\section{Impressions}

and the wild beasts of the boundless woods are pictured to the mind. The tamed, stale, flat and unprofitable actual outlook utterly fades away. I, for one, verily see the past brought back again. The highway is no longer the throbbing artery of ceaseless trade. I tread upon moss, not the bare earth, and then, rested, walk as in a dream. It is now the old "bridle-stye" that the early Quakers knew. Soon I reach the nearest village, a colonial hamlet that has known no serious change since its natal day. It crystallized at a creek-side point on the old trail and to-day is and for almost a century and a half has been resting from the arduous labor of a week's excitement when, in 1756, an Indian powwow occurred about its oldest oak and twentytwo years later a little muttering of revolutionary thunder startled it again. Then it was that the door of progress was shut upon it and never from behind it has been heard one word of protest. Now, the world must knock with emphasis if it would be heard, and all too likely timid folk would merely peep through Venetian blinds in response and ponder over the desirability of further notice. Such was my wool-gathering as I passed by and reached the great tree that 
ante-dates all else, save the Indian trail hard by, now the very type of a village street.

Does this old oak wool-gather?

Here, amid rolling fields stands an old oak, the sole, remaining witness of a half millennium of change; perhaps of a longer time. Happily, it is immediately surrounded by the meetinghouse yard and that this should be encroached upon is unthinkable. What a grand thing if more old trees were equally safe. To reverence an old oak is ennobling. Every man is the better for it. This great tree stands for very much so far as every contemplative rambler is concerned and doubtless for much more for itself. We say frequently of a relic: If it could but speak! Herein this aged oak differs from an old house or old furniture; it can speak. It is not a poet's whim that there are tongues in trees. This oak is Nature's spokesman, too, and her only historian.

Standing now by the massive trunk of this great Crosswicks oak, I wonder what secrets are hidden in its heart. This is not so idle as crying for the moon. Trees are not as sphinx-like as the Sphinx. The passing breeze 


\section{Impressions}

stirs the few, crisp, frost-bitten leaves to life. Their rustling is not remote from words. The oak is talking or I am wool-gathering. It is a distinction without a difference. Oaks of earlier centuries are reminiscential. It was so today. It was all about the sprouted acorn that escaped its myriad foes; of a sapling among giants that became a giant among saplings; then from self to its surroundings, to the Indian who long since passed away and the colonist that came; and after that the day of the sovereign people of an unkinged country and all that it has cost since to reach the present. All this and a vigorous tree still.

Herein the oak is happier than the man. It has grown great without great effort. All that man does but opens the door to more that must be done and men so often die early, old beyond their years.

A winter-day walk need not be a walk in vain; not, at least, if the wool gathered by the wayside proves worth the gathering.

No hand outreaching from another world has ever beckoned me to follow it and find myself a stranger in a strange land. I have never heard 


\section{The Rambles of an Idler}

an unfamiliar voice but clearly belonged to this substantial world and whose words had aught to do with other than life's realities. In brief, nothing of the nature of a ghost has ever come within the bounds of my experience. Prosaic fact has ever been my portion. Yet, had I chosen, ghosts might often have held me in bondage.

While cobwebs, dew and moonlight are common phenomena separately, they are sometimes so cunningly combined that not one remains itself, and associated they play ugly tricks upon us, in spite of all we can do. Some among us have seen the pastures glisten at sunrise, where webs, like fairy napkins, were spread upon the grass. Then we were given over to admiration and of course were brave. But stitch together a few of these and hang them on a tree, where the moonbeams will find them, and then the familiar woodpath leads to regions of doubt, if not despair. At such a time, unless we are brave far beyond ordinary mortals, we shall think of ghosts and pause if not retrace our steps. Many a veracious man has sworn he has seen a ghost with far less reason for so doing; but let an owl hoot and it 


\section{Impressions}

will seem to be an earth-born voice; even the big bullfrog will not be recognized. Every voice of the night will center about the cobweb-no, the ghost.

That calm, common sense which is our pride, the judgment we boast of when we encounter difficulties, the logic which we learned at school, all that goes to the making of a man, vanishes into thin air, is scattered by the whispered breath of fear, when cobwebs wave in the moonlight. It is strange that we are seldom satisfied with the simple fact and are so prone to invest the actual with fanciful conditions. "Nothing if not marvelous" is a popular motto. It is all very true that a straight line is the shortest distance between two points, but because this is true the straight line is not in favor. It reduces life to too simple an equation. We must be forever travelling around Robin Hood's barn to be satisfied. No one thinks of walking straight through it, even if the doors are wide open. Spiders may spin their silk; that is nothing. Moisture may condense to dewdrops; that is less. The moon may shine as it never shone before; who cares? 35 


\section{The Rambles of an Idler}

These three simple facts are too commonplace for us, and Nature altogether too prosaic for our mystery-loving souls. The earth is not for our feet; we must tread on air. We weary of the homely beauty of simplicity; we must see ghosts. The real ceases to satisfy, we crave the unreal, the unsubstantial, the feverish lie rather than cool-headed truth.

Cobwebs and consistency make a rare-combination for a winter night's meditation. We claim to be consistent and resent any hint that we are lacking in this virtue. Nothing if not practical is our boast. We glory in the conclusions of the truly learned, yet, if it chance to be dark and a clammy thread of gossamer crosses our face, we stop as if struck with a rod of iron. That single, delicate thread, the tiniest twig will break, is a cable of vast strength our nerves tug against in vain. We feel for the moment as if Fate had decreed the end of our career. All the while, we know it is gossamer, but lose faith in our knowledge. Very consistent when not even a fool is deceived, but shut out the light of day and every pygmy is a malicious giant. It is as difficult to be consistent as to be candid, and little the credit, if we succeed. 


\section{Impressions}

A cobweb can deflect our course as surely as rocks turn aside the current of a brook.

Not all gossamer is spider-web. We love the flimsy so well that we readily take to dainty nothingness and half our lives dally with unrestrained thought, the gossamer of idleness, that weaves a chain about us which we could break if we would, but never do. We hold, whether logically or not, that the gossamer of our own begetting deserves better treatment. We nurse it carefully, we humor its whims, we become its willing slave, and all the while the world is waiting for us to do our proper work. What an immense showing would it make if we did half we might do. Instead, the world too often has reason to wonder why we ever were, so trivial the impression made by us. A good epitaph for many a head-stone: "Enslaved by gossamer."

If it be true that "he is a freeman whom the truth makes free," then the naturalist is fortunate in escaping from bondage, for the cobwebs that are everywhere have a significance of their own that it behooves us to consider. Nature meets with no accidents and leaves nothing ly- 


\section{The Rambles of an Idler}

ing about, having no purpose. Cobwebs are not rubbish and tell their own pretty story to the patient listener. Whoever is willing to trace their history is abundantly rewarded. They lead us into the presence of spiders, and these, in turn, are not as uncanny as is generally supposed, even if first cousins to scorpions. Our interest should not diminish because some of them will bite, but increase because of their skill as engineers, for many a suspension bridge was built by them before man thought to span our rivers with a wire cable. Then, not all cobwebs are airy threads strung from chance pillar to post. They are sometimes hinges to neat doors that guard subterranean homes, and again are cords that bind together sticks arranged in cob-house fashion; but more noticeable than all is the closely woven fabric that is spread out temptingly as a pleasant play-ground for the foolish fly, but is not so desirable as it looks, for the insect's feet stick fast, and the weaver of the web knows he has a victim. Every web has a purpose distinctively its own, and how readily we enter the broad field of speculation when we come to consider the cause behind it all, that of specific differentiation; for 


\section{Impressions}

there are spiders and spiders and it is always easy to gather a dozen or more that vary greatly in size, shape and color. They are everywhere, too, and not an unknown factor of a midwinter day. Some even live in the water, carrying a supply of air to their webby nests beneath the surface. How easy to speculate how all this came about and yet, not yet are we advanced to the point of positive knowledge.

But above all these dreary details stands out the one great fact that among the least conspicuous of objects in Nature there often lies a wealth of beauty, wholly unsuspected. It is not "how much more beauty God has made than human eyes can see," as Ruskin puts it, but how much more than we are willing to take the trouble to see.

Cobwebs! Mention them and we have a vague impression of dust-accumulating threads, if they be in a house, or, if out of doors, they are but evidence that horrid spiders are about. But down on your knees and examine one more closely than ever before and then cease to brag of human skill in lace-making. Man is but an imitator and often a clumsy one at that. It 39 


\section{The Rambles of an Idler}

does not take a magnifying glass to prove it. It is well to be self-centred. Bacon declares "it is a poor centre of a man's actions, himself," but only by selfishness are we sure of self-development and thus man can make the most of himself; and his nearness to excellence improves his neighbor, for we all profit by the examples set before us. We are more imitative and less original than we think, and yet fail terribly in the line of closer observation of what the world outside of humanity is doing in so far as being profited by what we see. Everywhere the world is teeming with valuable suggestions. Not a beast or bird or spider but can give us a useful hint, yet we turn our backs or see with vision so oblique we had better not see at all. We make much of the silk the spider spins, but not to any purpose. Folk-lore rhymes concerning weather are our nearest approach to wisdom so far as cobwebs are concerned. How we pride ourselves on what we are, yet scarce a man but has cobwebs in his skull. Thought, light as gossamer, flits through the brain and we smile approvingly and call it wisdom. Perish the thought that we may be mistaken! 


\section{Impressions}

The glittering dew-drops, whether on cobwebs or on the grass, continually recall an $\mathrm{Al}-$ pine morning when the world sparkled as it has not done since. I made prompt record of it at the time, fearing some minor detail might escape.

By so much as the thickness of a pane of glass we may be kept hopelessly far from the actuality of Nature. He whom we pass by unheeded is but a man to us, but when we stop and shake his hand and, eye meeting eye, say, "I am glad to have met you," we are face to face with a friend. So is it when we are outof-doors. It is not enough to walk the length of any beaten path or make a short cut across untrodden fields. Nature is there, it is true, but not as a friend,-as a stranger. We can never stand as far aloof from Nature as she forever stands aloof from us. We think too highly of ourselves and too lightly of that upon which we are irremediably dependent; hence the widespread ignorance which matters nothing to Nature, but everything to ourselves. The seasons come and go; winter's austerity and summer's genial ways are not solely for man's welfare. They were the way of the world be- 


\section{The Rambles of an Idler}

fore man appeared and will continue long after man has vanished.

Humility befits us, and never more so than when we venture to determine what of the day just ushered in; what of such an Alpine morning as this, when frost encrystals every leafless bough, and every withered blade of grass glitters as if heavy with diamonds. We know what it means in a plain, prosaic way-that the moisture has congealed, that the brook is icebound, and that the drifting sands of summer are now firm as any rock; but this is really not enough to know. We soon learn, if we so desire, that we are not the only living creatures abroad on such a day. We have company, for there is reason to believe that even crystals are not inanimate. It was an absurdity, not long ago, to speak of "living crystals"; not so now. The researches of physicists have added a new chapter to the "fairy-tales of Science." But Tennyson here had better be misquoted that no mistake arise. Rather the "long results" of Science and the rest of it all, the fairy-tales of Time.

Perhaps we are not as good as our grandfathers, but we know more, and would extend 


\section{Impressions}

our horizon still further if we did not so persistently simply take a walk, but instead boldly plunge into the fields, ready to greet whatsoever we meet in the spirit of fellowship. Man is not so infinitely high and wild life so infinitely low that the chasm cannot be bridged. Deny ratiocinative power to the nimble hawk and hold that the frightened snow-birds are impelled only by blind instincts: what matters it? They are companionable if we so will it, and that of itself makes glorious an Alpine morning. We think only of the cold when we are too lazy to think of anything else. Visions of the fireside will cease to pursue when we have the faith of the birds and keep warm after their fashion, accepting the conditions as we find them and, ceasing to be refined equatorial savages, become sensible Eskimos.

No laboratory or museum is so complete a microcosm that the macrocosm can be safely ignored. The specialist amid his glass jars may sneer at the unmethodical rambler, but whose is the wider horizon? Carcasses may keep intact in formaline or alcohol, and learned labels smack of profound knowledge, but where is that subtle something which came into being 43 
with the body and which gave it that blessed charm which enraptures the lover of the outdoor world? Perhaps it counts for less than bone or muscle; but let it remain an open question that he who loves the living creature may have some ground for being its champion.

An Alpine morning. The microscope may trace no movement in these omnipresent crystals now, but they glow with color, are flushed with warmth. The sunbeams make merry with their many faces. The fields are not suffused with light, but rainbow dust. It is a fairy world into which I have rudely thrust my awkward self. But living crystals alone may not suffice. We who crave companionship on so mighty a scale call for nearer kin, and not in vain. I would that the mystery of a bird might be forever solved. No one, I dare aver, has seen until today, in these fields, those living buntings of the north, the white and mottled "Snow Flakes" of New England.

It would be comforting to have someone tell us how these birds of another zoölogic zone knew that conditions to their tastes here awaited them. T'he explanations, to date, do not explain. They fill the void with words in44 


\section{Impressions}

stead of facts, and we are still left to wonder whether these arctic buntings fled before a storm or journeyed with it and can do no more. Such rare visitors and the movements of our proper door-yard birds have given rise to many a "weather-proverb," and there it rests. The truth is yet afar off, but our interest never ceases. Suggestions have their brief day and are relegated to oblivion, or are kept alive by the charlatans who delude the masses.

These irregular appearances of certain birds have nothing to do with migration, which has been scientifically studied and, in great measure, explained; but rather with that sudden coming and going of all birds with which we are familiar. That the weather has its influence on animal life is evident to all, but foreknowledge and its concomitant, foretelling, are not unlikely peculiarly human attributes. On the other hand, birds can scarcely be denied intimations of approaching changes, or a forefeeling that influences their movements. That atmospheric condition which makes an aneroid possible and sends the mercury up and down its thirty odd inches of tubing may well play upon a bird's feathers. The result is noticed and the 
cause ignored, and upon the former has been founded the "saying" which had its value in the eyes of our ancestors.

It is strange that, days like these, prosy thoughts should intrude upon us. Such crystalline outlook should give rise to crystalline thought. Should! but poets are not commonplace creatures, present on all occasions. The glowing spirit of a cloudless day, the wheat sifted from the tares, the gold from the dross, the soul from the body-not all this can help the plain man who yearns for that beyond his reach and so is cursed, not blessed. Let these snow-buntings play the poet's part.

Theirs is no machine-like method of entering upon any scene before them. The snow, the ice, the crackling twigs as they rattled in the breeze, were really nothing to stare at, as I was staring. These birds were one with every sight and sound, living fruit of the perfected winter. Their white feathers glistened as veritable flakes falling among the trees. They twittered, too, in tune with the rattling of the brittle ice: one with Nature, as birds ever are, and in nothing alien, as man in all things is. As well separate the bits of a mosaic as take these bunt- 


\section{Impressions}

ings from the scene. Not they alone, but snow, frost, blue sky and rosy light, were a whole that nothing could surpass, and how vain the hope that one may tell its story! Words ever fail us when we need them most.

Nothing could have been more suggestive of freedom than each one of these birds, yet, as it proved, there was a bond among them that not one disregarded. Their happiness was in association. A sharp alarm-note sounded, and as one they rose into the air and were gone. A strange feeling of loneliness came over me. Crystals are relations of too remote degreebeautiful, indeed, but we lack the skill to interpret their message. Not so the bird. Our heart goes out to it, notwithstanding never a truer line was written than this:

"There is no more exquisite poetry in the world than that which lies in certain departments of science, and there is nothing more poetic in science than a garden of these frail, strange, exquisite ice-plants, composed only of frozen dew, arranging itself in leaf and flower forms and glittering like burnished and frosted silver in the sunlight of an Alpine morning." 


\section{The Rambles of an Idler}

"A bird of the air shall carry the voice, and that which hath wings shall tell the matter."

There is a good deal in a name, so much, indeed, that we cannot free ourselves of its influence. I found ice this morning long after sunrise, and looking miles and miles away, over upland and meadow, saw not a single green thing. The bleakness of December everywhere prevailed, but not with the same feelings as I would have then did I look out upon the world. It was April first, and that day and date presents its claims in no uncertain way. Not all it stands for can be held back. I waited but a moment to have the mystery cleared. There was a clattering in the treetops; a flock of purple grakles had brought the message of the month-a bird of the air had carried the voice . . . that which hath wings had told the matter.

It seems positively cruel to awake, at times, to the fact that our impulsive explanations are whimsical. Even these noisy grakles were positively musical while I fancied them bearing a message from April to the expectant earth. But if we are brought rudely to face the fact that they were merely singing after their fash- 


\section{Impressions}

ion, we can, at least, logically conclude that they were expressing their satisfaction because March winds were no longer blowing, and this, in a way, is a message from April to them, and indirectly to myself; so my first impression was not very wrong. As in many another case, we can approach the truth, but never quite reach it. All that a bird's song signifies we do not know, although books have been written on this single subject.

Even if silent, which is rarely the case, a flock of purple grakles, or "crow blackbirds"' as they are generally called, means a great deal to the rambler. The sky has long been only an empty space, but these birds fill most acceptably the aching void that jas been vexing us. To-day, as I looked and listened, I dropped from the contemplation of music to mathematics, and man can take no longer leap. The number of birds in the flock roused my curiosity, but their restlessness made even a crude estimate impracticable. When I thought I had them all in the field of vision, a hundred or more would be added. It is safe to say that there were more than a thousand. Think of that, and every bird chattering his loudest. How like a crowded 


\section{The Rambles of an Idler}

parlor! Yet how unlike, for there was meaning in what the birds uttered. Is it not written, "A bird of the air shall carry the voice, and that which hath wings shall tell the matter?"

What matter? What can it be now but the message from April? What would she have us know? He is bold, indeed, who would attempt to interpret what the wild bird says, but that he is Spring's messenger, there can be little doubt. Mankind has presumed to interpret every phase of Nature until not to do so becomes painful to him. This presumption is, of course, closely akin to sin, but deprive us of our pleasant peccadilloes, and there is very little left. I took the blackbirds' message as a marching order, and forthwith hurried to the meadows.

The little crepitating frogs were rattling and "peeping" until the air positively trembled, and the deeper toned voice of the leopard frog was not readily detected; yet had the former, present in myriads, been silent, the croaking of larger frogs would, by virtue of the volume of sound, have attracted instant attention. We marvel at the volume of sound, but would be 50 


\section{Impressions}

more astonished could we realize the numberless throats from which it issued. It is hard to realize what a million means, but I honestly believe that number not too great to include the frogs on the meadows. " $\mathrm{A}$ bird of the air shall carry the voice," it is true, but would the "disabused epicurean" who wrote our text have omitted the frogs had he heard them? They have not wings, but they "tell the matter." Tell it in so emphatic a manner that we forget the surroundings, for every foot of sod now is thick with the grave marks of an earlier year. All that I hear comes to where life was, not is; but the message is that life shall come again. Not a withered weed here but shall be replaced by a flower. Every frog now, as anon every blackbird did, asserts that better things are near at hand. To-day the burden of their song, It is to be-and very soon, no less cheerily they will shout, It is! Such a carrying of the voice; such a telling of the matter, is sufficient to keep the rambler long out of doors. The wreckage of winter no longer offends the eye. As we see the beauty of a structure before the scaffolding is cleared away, so through the dead grass we detect the coming greenness. Where the mes- 


\section{The Rambles of an Idler}

sage of April falls upon deaf ears there should our pity go.

Farther afield I heard the bluebirds warbling the same glad tidings in their inimitable way. For years their song has been to me inexpressibly sad, as if yearning for that which is irrecoverable; but not so to-day. They were bubbling over with joy. It was the song of years ago, before the days of their persecution set in. Nor was it only a few stragglers that were singing, but a flock. Since the blizzard of 1888 I have not seen half so many altogether. Here were fully a hundred bluebirds, each the embodiment of happiness, and, as I presumed, bearing the message of April ; not to me, I admit, but to the trees that towered above me and to the ground beneath my feet. There is no potentiality in a bird's song, but who can rid himself of the idea? It is too pleasing a fancy rudely to be brushed aside. As well accept a stone for bread as deal only in bare facts and ignore fancy. It is said there are people who have no imagination. Thank goodness! they but seldom cross my path.

Other voices were enlisted in fair April's cause as noon drew nigh, until I found no skulk- 


\section{Impressions}

ing bird. It was a day of universal rejoicing, a veritable jubilee. I said this, aloud, and the red wings took up the thought expressed, and surely a bird never spoke our language more plainly than these epauletted soldiers of the marsh-jubilee, jubilee.

I lingered until the westering sun turned my thoughts homeward, and, though the way was long and the path winding, I thought nothing of all this. Bird music is too tonic to permit weariness to creep in. Every mile was worth what it cost, considering the song at the end of it; and not a mile, nor a fraction thereof, without its attendant concourse of sweet sounds. The thrill of reviving activities was felt in the earth; a tremor could be fancied as affecting every gnarly old oak along the hill. Had rocks moved, I could hardly have been surprised. The message of April had been received; the summons was about to be obeyed cheerfully.

Let him who doubts look and listen for himself. He was neither blind nor deaf who said: "A bird of the air shall carry the voice, and that which hath wings shall tell the matter." Alas! how many are deaf to every message, so deeprooted is self-sufficiency. 


\section{The Rambles of an Idler}

I feel that I am lifted to the level of life's significance when the rose-breasted grosbeak sings. Cheerfulness, earnestness and the inwardness of labor are voiced by it above all other birds. That song alone is a message from one who has eliminated doubt from the earth's problems and bids us go forth and possess the land. I am urged, when I hear it, to serious undertakings,- to transplanting oaks rather than idly dropping seeds that transient flowers may bloom.

May-day can be as commonplace a date as any other of the series making the round year. We make much of many a holiday of our own appointment and practically nothing of this one, set apart by Nature herself as a time to rejoice, yet no occurrence concerning man is fuller of significance to the natural world. Man -Nature; they are far apart. Which the greater it matters not, but he is wiser than his brother if on this auspicious day he flees from the entanglements of civilization and turns savage; gets again as near Nature as he can, and asks every bird and tree and flower to be his boon companion. There is many a word in our common speech of which we know but half the 


\section{Impressions}

meaning; happiness is one of them. Go a-Maying and see if $I$ am not right.

Those who dedicated our fifth month to Maia, the mother of Mercury, knew Nature well and appreciated the fitness of things; but I suspect the chroniclers are wrong, and that she, herself, chose it as peculiarly her own and gave to it her name. Truth, for once, is of little moment, and I prefer my own fancy to the declared fact of another.

This is May first. Yearly reincarnated, she was present when, in an absolutely cloudless sky, the sun rose. The thrush, robin and wren knew the date as one set apart from the routine of the year, but they gave place to the grosbeak. He was May's chosen trumpeter to-day. The day, the hour, the outlook, are spiritual now and voice themselves in the song of a bird. May-day calls for no Quaker-like simplicity. Secretly we all love pomp, and so fancy the songs of May-day birds the announcement of our coming, as though we were really the lords of Creation. We can go a-Maying backward, as when we have anticipated all we look for; or go forward, all expectancy, disregarding past or future, accepting the passing moment as 55 


\section{The Rambles of an Idler}

the only gift of the gods. I prefer the latter.

There were dandelions in the dead grass before the winter was over, and all through April there was green grass where the sunshine longest lingered; there were singing birds to break the monotony of March; and yet to-day we have the impression of a swift transition from grave to gay, from shade to sunshine, from silence to music, from neutral tint to brilliancy of color. Not true, indeed, but let us be no stickler for the naked fact. It is hard to believe fancy has no right in the world.

Suffice it that this is May first, and let us see the world in a May-day spirit. Here are a blue sky and snow-white clouds seemingly suspended from it. The distant horizon is a less broken line than it was yesterday; the leaves grew in the night and straightened it. Buds are blossoms. The old gray world is now a new green one, and the rejuvenation is not Nature's only, but ours also. Coincidence only, as the dry-as-dust remarks, but who cares, seeing it is a happy one?

There must be wildness in the air and we must feel it. The scream of the hawk, heard, as it is, above all other sounds, is as the voice 


\section{Impressions}

of Nature when she asserts herself. We listen, then, not because we elect to do so, but because of the demand made upon us. It is Nature's authoritative tone, that none but a fool would attempt to disregard.

In what consists this wildness? it may be asked. In everything. May is not a savage, but she is wild. She is a child of Nature, and only such are free from all we would forget when we go a-Maying. When May arrives, the long-housed mortal must get out of himself as well as his house to find himself at home. She exacts that her guests be as wild as herself. True, she bade the rose-breast be her trumpeter, but she demands also a choral announcement, and it is ever at her bidding. Never a mute May day. There is life enough and abundant sociability in the babbling brook and murmuring tree-tops. When there is anything lacking out-of-doors, it is in ourselves.

Here is, I think, that which sets the month of May apart from all other times of the year; we forget the truth and feel as young and fresh as the expanding leaves. The dust of age is wiped away, and the glitter of youth, once ours, is seemingly again in possession. The cheery 
whistle of the cardinal, for example, is a rejuvenating sound. It not only falls upon the ear, but fills us from top to toe with music. We are thrilled. We heed as well as hear it and respond. It is as natural to shout our gladness on a bright May morning as it is to remark solemnly upon the weather during other times and seasons. We repeat the messages of the birds and find scant charm even in our own conceits. One with Nature on a May day is a full measure of delight. It is easy to forget that we are of many millions of people, if these many millions will kindly keep out of sight and hearing.

o Solitude, where are thy charms?

Where? Here, in these old woods.

"But when these woods are silent, what then?"

Silence is a rare occurrence in the woods or out of them. If there is not breeze enough to stir the fresh, green leaves on the trees, there is pretty sure to be a mouse to stir the dead leaves on the ground. Somewhere a shrill voice is shouting all the time, and if we hear nothing of what immediately surrounds us, the voice in the distance will reach us even if but as 58 


\section{Impressions}

the ghost of an echo. Silence is as easily broken as are promises. We have but to listen to our own breathing to fill our ears. Silence is a portentous word, standing theoretically for a stern fact, but theoretically only. Practically it is only a relative condition and a marvellously happy one. Silence, Solitude, Self!-as pleasing a combination as our wills can conjure up. These obtaining, we can do as we please, or, choosing inaction, think as we please. No better time than this to sift the chatter of the last crowd we mingled with, and perhaps gather a grain of gold from the infinitude of chaff. This triple condition is a better one out-of-doors, as in these woods, than in any house. The house is ever a museum of distracting objects. Books, pictures, chairs and tables lead us from our natural to our artificial selves, but not so outof-doors. Trees, birds, flowers, water, earth, sky-nothing in these runs counter to wholesome natural thoughts. We blend with all about us; not out of place, but accurately fitted, as Nature purposed, in that marvellous mosaic we call Creation.

Silence is a condition so largely of our imagination that it need never be seriously consid- 


\section{The Rambles of an Idler}

ered. Its rarity gives it a genuine interest, and it is never so long-lived as to become monotonous. I think, if I were in an absolutely silent cell, the singing of the birds would come to me at will, and I could laugh at walls however stoutly built. Now I have no need to deal with theory or put in practice any fancied condition. Nature is ever voluble in May. The moments between the songs of thrush and grosbeak, wren and oriole, chewink and chat, few and far apart, are filled by chanticleer in my neighbor's barnyard.

What is often felt to be silence and spoken of as such is but the rhythinic pulse of Nature, that rapidly intermitting hum of life which ceaselessly wells up from the warm earth. Night or day the teeming millions of the marshes, the meadow brook, and dark, damp tangles in the upland woods keep theoretical, perhaps mythical, silence forever in the background. Did we live the year round wholly out-of-doors, I think we would forget the very word silence. If we make a bogy of this same silence, we should not complain if it frighten us.

The restless rose-breast has returned, and why heed the non-existent? I have wandered 


\section{Impressions}

through the books on birds in hope of finding justice done this perfect performer of our woodland choir, but find nothing approaching it. The rose-breasted grosbeak sees the world more sanely than does the thrush. It has no patience with the nonsense of the catbird or the chat. Poet and musician, it gives its thoughts a worthy setting, and never frets us with a jarring note. To be glad with its degree of gladness is an ideality of life,-for us an unattainable goal, but an excellent one to keep before us. Ever aiming at the inaccessible, we keep, at least, in the one path, a straight one, and singleness of purpose is excellent, if that purpose be worthy. I, forget more of all that I would forget when listening $t \mathrm{c}$ the rose-breasted grosbeak than when I hear the song of any other bird. Nor need one wonder why. It is an exultation over perfect happiness attained. All else that is heard is not without a trace of melancholy or doubt. This alone is the outpouring of a merry heart, yet weighty with wise thought withal.

This day our journey never need be long. An old apple-tree is an appropriate goal. When we have fathomed what trunk, branches, leaves, 


\section{The Rambles of an Idler}

blossoms, and their attendant bees and birds stand for, and can tell our less observant brother what May-day means, when the hum of insects and songs of warblers fill the air, then we do not need a day out-of-doors; but I have never met with such a man. Indifference is not evidence of a lack of need. Not all the lectures, sermons, books and museums in the land can take Nature's place. To be with her daily is the greatest of our blessings, but this cannot always be. To catch merely hap-hazard glances is but to learn what we are losing. If, at best, we must choose an occasional day, never omit this magical date. As I have done and am doing-go a-Maying.

That which keeps me wholesomely alive, as I wander to-day, is color-blue, pink, yellow, red, and white. May blossoms are everywhere. Violets, azaleas, buttercups, columbines, and wildflowers, all intensely in earnest, gazing skyward boldly, expectant of May's assuring smile. They clearly enter into the spirit of the day and shame us for our half-heartedness. The idols of Artificiality are something more than wood and stone; they have cast a veritable spell over us. Sound, alṡo, keeps me whole- 


\section{Impressions}

somely alive. Not alone the singing of the forty different birds that I have seen, but the undertone or thrill of earth's renewed activity. Insects in the grass, frogs in the water, the breeze that toys with the baby leaves, these are the constant sounds that are unheeded and unheard if our thoughts continually revert to the town, but speak in no uncertain way if we have ears to hear and a will to heed their message. May hath pithy speech, yet plain. No vague intimations are hers, but all is of clear intent.

Innocent as the blossom, joyous as the bird, earnest as earth's manifold activities, this is she who wishes only that they who ramble abroad this day may be like unto her and so remain.

What more detestable than wet days in May? What ought to be, is not. What is, ought not to be. Let the rain come in the night, if it must, and then make way for sunshine. Such is the thought of the average healthy man.

Now that a recent May has passed into history, I am inclined to take back all that I have ever said in favor of the month. Like the cor- 


\section{The Rambles of an Idler}

responding month of the preceding year, it has been more a series of disappointments than of realizations. I write these words without misgivings, and although, when the east wind was most cruel, the wood-thrush sang in that exalted strain that lifts us to a higher sphere. This song of the wood-thrush is evidence of near approach, in one direction, to perfection and it is well so to be entertained by it that we are blind to how short we fall of attainment in others.

One May, I recall, had but little to boast of, and another, later, had less. Eighteen rainy or cloudy or foggy days is an excess of pluvial and allied conditions that would figure well in Patagonian or Labradorian outings, but out of place in Nature's remnant of Elysium, New Jersey.

And yet,-the signal of a sober second thought-the catalogued phenomena of the month has no missing pages, nor breaks in its columns. The trees grew their leaves, plants produced their flowers and the birds returned. Search where we might, nothing was lacking and yet we could not accept the offering as May; that is, as poets picture her. 'The trouble 64 


\section{Impressions}

is, these imaginative folk have so warped our minds that we look for more than we can reasonably expect to find. There is a pane of glass in one of my windows that has a twist in it, which lifts every little bush from the ground and makes of it a long, slender Lombardy poplar. It is so with the poetry that we have relied on for our ideas of May. Every bush a tall tree; every blossom, a bouquet, and, worse than all, every hour flooded with sunshine. We have had our faith undermined and tempers spoiled. by teaching that later we have to unlearn. There is no one that does not rebel when it is stormy or cold in May. The man who professes to be content and preaches patience is to be watched.

The statistics of the Weather Bureau are saner than the effusions of the Spring poet. The return of the seasons, and what they are, we know by name rather than by nature, and should expect nothing. In every twelve months there is a round of changes, but no very orderly procession. The seasons may have a path but they do not keep in it; so too, the months have their allotted phenomena but they lack method in handling them. 
Expect nothing and so be rich in preparedness. Set your picnic for the first fair day and specify no date. Learn that dependence on the weather is like trusting to luck, a sure way to be miserable. That you may become better acquainted with facts, why not, at least once in your life, picnic in the rain? Perhaps the birds will not sing, but pass the day with them, whether they do or not. Misery loves company.

An ideal day is one that is suggestive. We must see something about which to think, later. The harvest of an out-door day should be food for thought. Not all gray skies are akin to wet blankets, for sunshine does not reveal all the earth's secrets. How Nature affects us when she frowns is no matter; but we are concerned with her scowling effects upon wild life.

Clear or cloudy, accept no day as typical. Cloudiness and fog are not depressing. It is only the wind that the birds detest. The catbird is really musical now, almost an equal of the thrasher, but not so persistent. Its tendency to fret never so far overcomes as not to permit finishing a pleasing song.

Today I saw a pretty sight. Leaves all dripping, and the cat-bird, perched upon a twig, 


\section{Impressions}

sent down a shower of glittering drops, and dived in time to pass through it. Then, with great spreading of wings, the bird shook off the drops that clung to it and sang or laughed-at least I thought at the time that it laughed.

I thought! We describe what we witness in accordance with the way we enter into the scene. It is possible to see only motion and all that suggests association of incidents can be cried down as coincidence. True, and equally so, that every community, however small, has its dunce. If there were no pleasure derived from interpretation, better stay away from $\mathrm{Na}$ ture's activities. It is vain to question her. She is close-mouthed and we should never forget that she would move on in her own mysterious way just the same, if there never were a man in all the world. Evolution merely happened in the direction of humanity. To Nature, we are of no more importance than so many cat-birds. If we were not of some importance to ourselves, we should be of none at all.

One little bird was very insistent, this morning, saying, It is, it is, it is, it is I I too admit "it is," but does my "it", and the bird's stand for the same thing? If the bird feared I should 
forget it was May, the fear was groundless. I shall not forget. May days are all matters of joy except when I am forced to go to town. The scattered shade trees there make me homesick.

A puff of wind shook the drops of water from the leaves and these falling on the spreading skunk cabbage beneath, made a great clatter. I looked sharply about me, thinking some animal was running by.

It is beautifully clear to-day, and if a year ago, in all the fog and damp, there was so much to see and hear, how much more now, when a blue sky and abundant sunshine give the cue to general rejoicing.

A pretty view to take of the subject, but as unwise as possible. To-day, there was the frostiness of winter, a suggestion of January came back to us and I could not find even where the birds were hiding, every one kept so close.

I expected little on a former May day and saw and heard much. I supposed there would be much to see, when I started out this time, and I neither saw nor heard anything. Wild life 68 


\section{Impressions}

judges for itself as to the weather, and to set up our standards for its guidance is to publish our own foolishness. We forget this potent fact too often.

At noon, on a recent May day, the warbling vireo and its red-eyed cousin were heard about the house, and in vain, to get rid of them, did I go farther and farther afield. Both have querulous, tiresome songs, that become positively exasperating, when we wish to listen to the less pronounced notes of other birds. There is nothing suggestive in their monotonous reiteration, unless we look upon each utterance as the death-knell of an insect, and we need not add this to our many reminders of Death's activity. The clock struck the hour, but a moment ago. An hour has just passed away, and by so much we passed with it. Give us livelier birds; one like the chat that amuses, the thrush that soothes, the lark that exhilarates, or even the crow that leads me, at least, to pleasing retrospection. I shun the red-eyed vireo before the summer is gone, for it becomes ere then like the mumble of senile dementia.

If I am completely happy when crossing a 69 


\section{The Rambles of an Idler}

quiet mill-pond, in a row-boat, at a snail's pace, why should I be envious of those who cross the Atlantic in an "ocean greyhound?"

Fixing our own goal, if we reach it, satisfies; I know not why we should concern ourselves about those people who are more ambitious. We hear much of a high aim, but if one nearer the earth delight us, why raise our gun? It is hitting the bull's eye that gives us the pleasure, not the lower or higher setting of the target.

Simple tastes and a humble occupation are full worthy of our regard, if we are at peace with ourselves the while. Envy works more mischief than all other of men's weaknesses. Content is the key-note of a life's success. I know that there are those who look down on me and sneer, but I am not disturbed. I look up at them and laugh.

While it was yet uncertain what the day was to be, so pale the light that flushed the eastern sky, a red-start suddenly appeared, as if a passenger on the latest puff of wind, and never a moment resting, began that zig-zagging among the tree-tops that will not end till the close of summer. This bird is a "warbler," but its 


\section{Impressions}

note suggests unoiled machinery; a grating sound; a squeak. All these interruptions of the silence, in a way, are welcome. They are assurances that Spring is really here. Last autumn and winter were good, but now it is Spring and something better, and soon summer, best of all. Best? Perhaps it is, but is there not a wiser view, that of accepting each season so cheerfully that it is perfect while it lasts? It would be better to drop our choice of seasons. These May days are perfect ones of their kind, but let each day, month, season, as it passes, suffice us.

May, magnificently arrayed and superbly attended, we can think of only as a sovereign-a gentle queen. So, at least, she has often been; but sometimes she is a sobbing, sorrowful queen, copious tears falling nearly every day.

To-day I measured this year's growth of a young ash. It is twenty-two inches taller than six weeks ago; and a young beech has a new growth at the end of every limb, but is four inches shorter than the ash. If we sowed the seeds of trees in youth, we could walk in a forest before old age appeared. 
In a dead limb of a linden tree, near the kitchen door, about thirty feet from the ground, a pair of flickers-golden-winged woodpeckers -have their nest. I think it was dug out in a single night, for the white chips, like great snowflakes, covered the ground early one morning and no one appeared to have seen or heard the birds while at work.

These woodpeckers are not at all shy, but properly circumspect. They are nothing for the rattle of pots and kettles beneath them. So long as the latter keep to the ground, the flickers will enter no protest. The fact is, and it is true of all birds, that it is not always noise and bustle that frighten, but the kind of disturbance. They are quick to discover if any activity on man's part has to do with man's affairs or is directed towards themselves. These dooryard flickers were circumspect for a few days and now they are tame.

The house-wrens still nearer by may have given them assurance that all was well, but this is very doubtful. They are too far apart, structurally, to associate, and intellectually very unequal. What queer birds are these wrens! I could pick out a dozen excellent nesting sites for 


\section{Impressions}

them, but not one is occupied. Instead, one pair of these birds have chosen a tomato-can turned upside down over a stake. Great skill has been exercised to secure the nest, as there is little room, the stake being large, and, to make bad matters worse, the can sways a good deal whenever the wind blows. Until some observer secures a wren's point of view and explains it all, such nesting sites must remain evidences of a wren's lack of wit, from our point of view. I would much like to read a natural history of man written by a wren, or, indeed, any creature not a man. It would have one quality not always found in men's books, now-a-days, originality.

We occasionally hear an unfamiliar note and usually wonder what bird uttered it. We forget that most of our small animals also can be noisy on occasion. I once followed up a boy who was tending cows in the meadow, thinking I was on the track of some rare visitor to these parts. As he told me, he was 'tryin' to' shape a tune to some po'try he'd made up." Since then I keep in mind the possible sources of sounds I hear other than birds. Only recently, 
in a green-brier tangle, I heard a shrill cry that puzzled me. Before I had forgotten it, chance solved the mystery. My dog ran down a weasel in the grass and wounded it. When I came up, it gave the loud, shrill cry that when previously heard I could not identify. In this case, it was distinctly a cry of distress, but is it always that? Cram mentions a weasel "uttering a sharp chirp like the alarm notes of certain species of warblers," but the sound I heard was a shrill che-ee-ep! twice or thrice repeated.

Recently, in a single ramble along the hillside, my companion and I found one nest each of a yellow-breasted chat, a cardinal grosbeak and a summer warbler. There was no attempt at concealment in any one instance. If a cow had nibbled off a few leaves, the nest would have been exposed even more, and such an occurrence is quite possible. There were thickets near by, no animal could have gotten through so as to reach the nest, yet these were not made use of, but instead a bush on the edge of wide open spaces. It looked much like trusting to luck, which is closely akin to being very foolish, if not really the same thing. 


\section{Impressions}

A fall in temperature of sixteen degrees caused marked changes in existing conditions. Four really warm days sufficed to set June's machinery in motion. The month was in running order and all animate nature accepted the conditions thankfully. Only those people who have de-naturalized themselves complained of the heat. Then a cool wave from Montana and all was confusion. The effect in town, I was told, was to start the senseless question: Are our seasons changing? In the country, the result was to silence a great deal of noisy life and put a quietus on a vast deal of activity.

Some time ago, in autumn, I cut from a bush and hung in the hall a large pear-shaped nest of the hornet. It held intact for a time, and when it became too shabby to be presentable, was removed to the side of the house, where it soon became an object of interest to hornets and house-wrens. The former explored its inner recesses continually; not, as it proved, to reoccupy the nest, but to carry away available bits for a new nest under construction elsewhere. This, at least, was the apparent solution of the matter, for no hornet ever tarried longer than 


\section{The Rambles of an Idler}

to reduce to pulp some of the old nest. Capturing several of these ill-tempered creatures, I failed to find any of the nest material about them, so I may be mistaken, but in the course of two weeks the interior of the nest was a good deal broken down.

For some days before the hornets ceased their visits, a wren came and my initial thought was that the bird, too, was after nesting material, but this was not the case. The place was now admirably adapted for a roosting-spot, and a day-time-resting-place as well; for male wrens, it would seem, occasionally get tired and appreciate a quiet corner where they can take up a thread of thought instead of forever tugging at the line of duty. This very reasonable view of life is disputed, however, and discussion more emphatic than polite sometimes occurs. It all would be very amusing were it not top-heavy with weighty suggestion.

Nature, unaffected by man's activities, is always near, and great areas of it often closer at hand than we suspect. An acre is but a mere dot on the map of many a farm, but let that same acre be a bit of woods or marsh, and at 


\section{Impressions}

night it seems a boundless wilderness. Try walking through and through it, this way and that, where there are no paths, and let an owl hoot in your ears and you will then know what I mean far better than words can tell.

It so happened I was in the immediate valley of Crosswicks Creek long after sunset, yesternight. The tide was well run out and long, low banks of mud were exposed. On these the night-herons were stalking or standing, sentinellike, and back on higher ground the toads were bellowing. Black clouds obscured the sky but left wide star-dotted spaces between them. There was no sight nor sound of man. Again it was the weird, wild country of the Indian or before his time. The mastodon might have sounded his shrill, trumpet-like cry and I would not have been disturbed. The wolf might have howled or the cougar screamed, but only fear would have been aroused. As it was, the fishes leaping above the surface of the out-flowing waters, the splash of the turtles sliding from a projecting stump or floating log, the warning cry of the muskrat and possibly that of the mink, forcibly reminded me that I was far from being alone. 
Night more frequently than day recalls the past, particularly such a night as this, and it was natural, on returning home, to take up Kalm's Travels in North America. More than once he was within three or four miles of where I had just been and he described in detail what he saw in 1748-49. Coming from the marshes late at night directly to his book, it was like a new world just from the press. As I read, it was the good old colonial time again, and I had seen and saw, book in hand, what were the familiar daily sights of my ancestors.

The sunny side of those days may not be made plain in the histories we read, but that there was such a side we all believe, though not more so than to-day. Surely there was a freshness and novelty then that is lacking now. One certain advantage of such experience as mine last night is that no element of deception creeps in. It is the same creek and the same sky above it that Kalm saw. If not the same trees, they are trees of the same kind that grow in the adjacent meadow; and then, toads, minks, muskrats and night-herons have not changed their language. Their message to Kalm in 1748 and to me one hundred and fifty-three 78 


\section{Impressions}

years later is identical. Here in the marsh there is no "antique" furniture palmed off upon us, made a year ago, by some cunning artisan.

A good old Quaker lady in her kindly ungrammatical way was wont to say to me whenever I expressed a determination to take a nocturnal outing, "Thee'll surely get the chills," but the warning was never heeded. A possible shaking should not frighten us off. It is worth the risk, considering there is still-an abundance of quinine. The serious part of it all is after the outing, when the story of it is to be told. The tamest thing in the world is a description.

There are so many strange sounds heard at night that only a visit to the woods or fields or a marsh such as that I have been wandering over can give us an adequate idea of the abundance of wild life still remaining and holding its own against ccaseless persecution. We realize now how many creatures, both furred and feathered, effectually conceal themselves during the day.

These were the sounds I recognized as I stood alone on the sobbing marsh, for the mud at this time-at low tide-is constantly sobbing, or 


\section{The Rambles of an Idler}

perhaps, more correctly, blubbering. I heard the night-heron and the great bittern, the yellow-breasted chat and a field-sparrow-this bird singing in its sleep-marsh-wrens, an owl, frogs, crickets, and, I think, the chattering of a flying-squirrel. These at once and the bewilderment resulting from the attempt at identification probably dulled my ears to many another sound. As deep bass to all those lighter notes was the chorus of innumerable toads that at times drowned the childish trebles of more airy creatures.

It is easy enough to enumerate, but no trick of words will make animal life stand out on a printed page. Here are a few names; the creatures are still in the marsh.

Through the three hottest hours of the day, the indigo bird sings without a break. It does not even seek the shade of a leaf. Are we to learn some valuable lesson from this fact or is the bird demented?

Because we gather a great deal of valuable knowledge through observation of the out-door world, it does not follow that all animals are wisdom personified. Interrupted evolution rc80 


\section{Impressions}

sulted in a foolish creature now and then and I think the indigo bird is one of them.

During these Graduate days, advice is in the air thicker than erer gossamer floated in the early morning. Excellent, in its way, some of it, but the inclination to swathe it in feverish rhetoric and to exalt the orator until the distance between the adviser and the advised is immeasurable overcomes discretion at times. To tell the class that has now finished its training for the great struggle, never to take a rest is nonsense; but clothe this same idea in an oratorical outburst, flowery similes and other tricks of speech, and the class and its friends applaud vigorously, and, very wisely, forget, the next day, all the speaker said.

Hamlet was set up, I notice, before a benchrow of graduates, as a failure and Fortinbras lauded to the skies. The former decried as a dreamer, the latter praised as a man of deeds; but all the world has heard of Hamlet and who but a beggarly few remember Fortinbras? The one, dreamer though he may have been, goes with us and delights us, wherever we may be; but no sooner does the curtain touch the 81 


\section{The Rambles of an Idler}

stage's floor than Fortinbras is so completely forgotten that we can only with difficulty recall his name.

Too much is said of this endless struggle for success, too often ecstatic to the touch and ashes to the taste. The positive curse of all this flourish of rhetorical trumpets is the setting up, not of high ideals, but of ideals at a preposterous elevation. It is shouted abroad at this season: Goad your ambition and reach to the unattainable. So far, bad. All too seldom is it advised: Curb your ambition and be content with moderation. Youth is set to run at a mad, killing pace and, prematurely grown old, has nothing in the end to show for a prodigal waste of energy. Statistins will bear this out. Why aim to be a comet that outshines all the stars? Comets are but transitory affairs. The fixed planets and the myriad stars serenely shining have a better time of it. Better to be happy in a modest way than miserable under the load of vast undertakings.

\footnotetext{
A later June day was that of General Nest Delivery among the robins. Young birds were everywhere and the old ones were in a state of 82
} 


\section{Impressions}

perturbation beyond description. They were simply an annoyance when I endeavored to make note of the released nestlings. These I classed, at the time, as climbers and flutterers, and interest centred on the former, as their success in clambering about trees and in tangles of green brier was quite marked. I saw nothing that could be called a mishap, but the flutterers often came to the ground and had endless difficulties in getting off it. They failed to judge of position and fell short or over-flew the perch they strove to reach. One young bird, having no faith in his wings, had marked scansorial skill, and I think more than once used his beak as a third means of support; that is, it climbed with its feet, balanced itself with its wings and pulled itself up by holding to a twig with its beak. So, at least, it appeared to me, but I will not be positive.

All the while the parent birds kept up an incessant chatter. The young appeared not to pay any attention to it and so it was, to me, a waste of energy; and should it not, theoretically, be dangerous? Such a commotion attracted my attention and so it should have called hither hawks, owls, crows, weasels and 83 


\section{The Rambles of an Idler}

cats. All these are fond of young birds as food, and could have feasted to their stomachs' content, but I saw not one. I, surely, did not keep them away, concealed as I was by the foliage of bush and brier.

I wondered, too, if the parent birds could recognize their own young from others of the same age. To-day, four nests were vacated at the same time and the young, a dozen or more, were wandering in the same trees. I could see no difference in them, but then, I did not see with a parent's eyes.

One summer the sink-hole in my field was full of green-herons. A year later they came in force but left very early, except a single pair. Now but two pairs are there, yet to my eyes there is no change in the spot. I think this shows how hopeless it is to determine, from our standpoint, the true inwardness of birds' doings. We are constantly misjudging our human neighbors, and if we cannot stand in their shoes, how much more improbable that our conjectures as to the birds should be correct. Why, too, this present summer, should the redeyed vireos have forsaken us? Surely there is 


\section{Impressions}

food enough for them, as the flycatchers and red-starts can testify.

On the eighth of the month, a man came to the "Three Beeches" to hear the Carolina wren. It is the one bird I would have promised a sight of, without hesitation. That day none were seen or heard, and none since, until today, the fourteenth. Comment is unnecessary.

I am sensible, this quiet afternoon; of a presence that distinctly influences me, although I am, outwardly, quite alone. I think I never come to this grand old oak but I have the same feeling. It is an oak worthy of a long walk to see. Still, all unmindful of the sad changes going on about it, it looks out upon the world with all the majesty of kingship in its noblest sense. An oak, a forest monarch when the Indian filed along the narrow trail that is still to be traced near it; a witness to the struggles of the colonists while there was yet an unbroken wilderness about them; and still marking the changes that the restless energy of man brings to pass. It is a long look backward from the electric railway to the Indian's trail, yet the life of this old oak more than encompasses it all. 


\section{The Rambles of an Idler}

Sitting as I do, I see no trace of recent change and hear no rumble of the passing cars. The quiet of an earlier century pervades, and in a delightful, day-dreamy mood myself, I feel that I have most pleasant company. Here dwells a hamadrvad that has a power to charm. There is no disturbing element. Not a harsh sound nor distressful confusion plagues me. The actualities have drifted until all is vague. Dreaming, I am yet awake, and sight, sound, smell, alike aid my senses in their airy flight. The hamadryad is so far real that I enjoy her company. She whispers of pleasant things only, recalling the happy past until it is real again and promising of the future such good things that the delight of anticipation will overbear the probable shock of promise broken. I would that every oak was blessed with such an attendant. Hamadryad, indeed! Whim of a poet? No, not this one. She is more real, more honest than half the friends we meet. As the devotee approaches the shrine, I came here as I have often done before and never was rebuffed. Here is the only altar I have ever faced. The work-a-day world may scoff at hamadryads. Let it be joined to its fleshly idols 86 


\section{Impressions}

and find comfort. This oak stands for something greater than the crowd. There is here a balm for the smarting soul, that neither pealing organ or men's words can impart. Trouble fades as a dream when the hamadryad whispers and the trembling leaves repeat her soothing words.

Although the sky was overcast and the lowlying fog, condensing, rolled in great drops of water from every leaf to the ground, there was promise of a pleasant day and that the passing shower, like the brief sobbing of a child, would soon be followed by sunny smiles.

At Four A. M. I was up and about and heard not the concert only, but that preliminary tuning up that precedes it. Here, without doubt, the robin is choir-master. His, it was, to sound the first note as the light gained foothold and the outlook merged from chaos to order. His to be the leader-but Caution cries, halt! Was the robin thus recognized? Is not each one of the several species of birds wholly independent of and indifferent to the others? We speak of the morning "concert"' because it describes the effect of united voices upon us, but do birds 


\section{The Rambles of an Idler}

take the same view of it? Did the thrush and the wood-pewee wait for the robin to give the signal? If so, why did they only, and not the song-sparrow, cardinal and rose-breast join in at the same moment? It is useless to conjecture. It is mere assumption that consideration of another's song ever entered a bird's head, but here is what happened,--

The robin heard the whispering dawn And knew that dreary night was gone; Then told the good news far and near, Shouted aloud that all might hear, "In sleep no longer drown your voice; Come, comrades, one and all, rejoice.

"Come, gentle thrush, thy hymn repeat, With sweetest chord the morning greet; Thou, jaunty red-bird, warble well Thy notes that breathe such potent spell; Welcome the quick, in-coming day, In thy persuasive, winning way."

From hillside-slope to river's shore, The meadows deep in brilliant bloom, Bid shadow vex them now no more; Aside they cast their night-long gloom;

The chains that bound the world were broke 88 


\section{Impressions}

The moment that the robin spoke;

No thorns beset, nor frosts defy

When blessèd June is passing by.

Brilliant indeed are the meadows in June. We can use no milder term and do them justice. The botanist can readily appreciate this, when I tell him that at one glance can be seen and from a few acres can be gathered in abundance, Phlox, Oenothera, Thalictrum, Penstemon, Erigeron, Iris, Senecio, Lysimachia and Cynthia. Grouping these, we have a mass of yellow, orange, pink, purple and ivory white that one must see to appreciate. Well might Shelley exclaim in despair, in description of another kind: "Words are ineffectual . . . Most words are so-No help!" $\mathrm{He}$ is surely rash who would attempt to describe a typical June morning, and meadows, for miles, one glowing mass of color. They mock our senses, not appeal to them in a way we can compass. As is the gibbering of apes to the speech of man, so is our best effort in sounding their praise to what their merit calls for. The saving grace of our words is that perchance others may see what we have seen. 


\section{The Rambles of an Idler}

It is not strange that as the month passes we often find ourselves in a profoundly meditative mood. I remember, as a little child, how eagerly I watched the preparations for the promised cakes for which I longed, and oh, how distant seemed the time when the dough was in the oven. July, August, September; these are the days when Nature is in the oven and the rambler must wait from now-the end of June -until October, before the feast is ready.

July, August, September! I know nothing so fitting to say of them as that in ninety days it will be October.

\section{THE CAT-BIRD}

A singing bird, an oak tree's shade and grass

That yet unwilted greens the gentle slope,

The leisured clouds that loiter as they pass,

To care a stranger and un-plagued by hope;

Grant, kindly Fate, like blessing; not deny;

All else, how little worth, in mid-July.

The fervent fields aglow with summer heat, The steaming marshes reeking in their mist,

Languid, the rippling river's pulses beat

Where tide and meadow-shore have heartless kissed;

They woo me not to wander hence, for I

Find all that tempts me, here, in mid-July. 


\section{Impressions}

Here, with the singing bird and in the shade

Where yet the violet retains its youth,

Where moss, I fancy, for my limbs, was laid,

Here sings to me the ever-welcome truth,

"No thought of haste as pass the hours by -

Life a long day-dream, now, in mid-July."

'Twas but a weary cat-bird sought its ease,

In quest of comfort all too seldom found;

Lulled by the murmur of the passing breeze,

Sought the cool, leafy shade above the ground

And cast a glance of pity from on high

Upon the toiling world of mid-July.

Then a brief message, slowly reaching earth,

Few whispered words, yet freighted well with cheer,-

"'Twas not ill-fortune frowned upon thy birth,

Since thou hast wit enough to seek me here;

For greater blessing do not hope to try;

Cool and content; what more, in mid-July?"

\section{Poet}

"Is that a worthy thought for man or bird?"

Cat-bird

"The only thought, my friend, I ever heard."

Poet

"No higher aim throughout this life for thee? Come, honest cat-bird, tell the truth to me." 


\section{The Rambles of an Idler}

\section{Cat-bird}

"What good, at last, is man's philosophy"

Better fat worms, or berries rich and red,

Than the vain problems that perplex your head.

Though, like prowling cat, I mew;

As flitting bat when falls the dew;

To myself, forever true

And cheer with song as clever

As any ever sung by you,

Full earnest your endeavor.

What if storm goes raging by?

Does it dim my sparkling eye?

Head at rest beneath my wing,

For the moment cease to sing,

Waiting, knowing, time will bring

Clearer skies and then I hie,

Though it be in mid-July,

To the happy feeding ground;

Food in plenty always found.

Take a lesson, then, from me,

Life is easy, would you see

The wit of my philosophy,

To Nature, blessèd, who belong;

With her army, millions strong,

Hold not idleness is wrong.

Freed from worry, join the throng,

Swell the universal song,

Birds and blossoms, field and tree,

Freedom and Simplicity." 


\section{Impressions}

\section{Poet}

" Honest cat-bird, can it be,

All is thine and naught for me?

Blessings only for the bird,

Favors seant for human herd?

Whence my shelter from the blast,

Raging storms that night-long last?

Whence my loaf and needed drink,

Nature gives them, do you think?

Wherewithal shall I be elothed?

Nakedness is rightly loathed.

Did I cease from daily toil,

Cease my weary hands to soil,

Cease my weary brain to use,

Nature would her gifts refuse;

Life is far from liberty,

If, cat-bird, you a man would be."

\section{Cat-bird}

"Slave of customs that unmake, Customs sapping half your strength;

Canst no hint from Nature take?

Wilt not wander any length

From the beaten path so deep,

You seldom o'er its edges peep?

Ever bird, without a care,

Would I be, as free as air;

Shelter, food and elothing fine,

With no thought of whence, are mine,

And the beauties of the world

Without effort are unfurled.

93 


\section{The Rambles of an Idler}

All you gain, ambitious man,

Enters nothing in my plan.

Free to come, to go, to see;

$\mathrm{Oh}$ ! ever blessèd liberty.

Heaven mine, un-reached by Hell,

My simple song is, "All is well.'"

Sage or simple be the thought,

Nonsense all the cat-bird taught,

Yet it pleased my willing ear

The cat-bird's earnest song to hear.

How gladly would its methods try;

Day-long on these mosses lie;

Wander to some far-off glade;

Rest within a cooler shade;

Borne by breezes passing by,

These seething days of mid-July.

"Fool to think it!" say you, friend?

Where does all our labor tend?

Toil and sweat from youth to age,

No thought of ease the heart engage;

Then full rudely thrust aside,

For another, opened wide,

The door, the moment that you die

And look upon eternity;

Loiters in the house you build,

Gathers from the fields you tilled

All the harvest - this the way

Burdened mortals get their pay.

94 


\section{Impressions}

Fool, I may be; be it so,

Yet while free to come and go,

This the silliness I teach,

This the gospel moved to preach,

'Better, eat-bird, ten to one,

Than harvesting in July's sun.

Why pursue the fruitless theme?

Mid-summer now and I would dream.

Dream that happiness was mine,

Dream ambition's height was reached,

Dream that toil I conld resign,

Dream that all the eat-bird preached

Was, at last, a world-wide truth,

And I again an aimless youth;

That life was living without care,

With singing cat-birds, everywhere.

Recently I chanced to pass by the three beeches as the sun was setting. Their massive trunks and far up-reaching branches impressed me, as they always do, and I stood for a moment reverentially, as one might in a great cathedral. A solitary thrush, not far off, sang in its own sweetly meditative way, suggesting the cathedral's organist dreaming over the keys. The prevailing subdued light did not obscure the outlook. It was instead so far penetrative that the more distant trees and thick-set 95 
shrubbery stood boldly out, but it did command all things to silence, save that lonely thrush.

My thoughts were quickly attuned to the delightful strains I heard. It was a season of meditation such as, I think, the one-time Friends enjoyed at Meeting, when their House stood in a spacious yard aloof from life's activities. Vexing problems of life disappear at such a time; there is neither a remembering; of trouble nor undue eagerness born of vain hope; content prevails and a willingness to remain completely passive, awaiting in fullest confidence the decree of fate. Into such a sunset light there comes no fear. Life is luxury, but to leave it then and there, no shock to us. It is, for the time, so near an approach to beatitude that death would seem but swift transition to where such blissfulness prevails forever.

Then, without warning, came a wondrous change. A rift in the leaden clouds let the red sunbeams through. Swift as the lightning, all nature was astir. The lonely thrush was roused to vigorous song and every warbler, quiet until now, joined in the chorus. All again was action; life was busy, full of aim and ambition; the old story of struggle, victory and 96 


\section{Impressions}

defeat, life for the few and death for the many, was being retold. I hurried to a leafier glen where yet a gray light lingered. It was more in accord with what attracts me. There are many trains of thought so pleasant, I never tire of thinking, but they wisely shun the red light. That is the signal of war and I am a lover of peace.

The attics of old houses have been pretty well ransacked-in imagination usually-but cellars have been overlooked. Now, as a matter of fact, cellars in old days were something more than square holes in the ground and meant more in household economy than now. They were divided into rooms and the milk-cellar, the provision cellar and the general cellar each had its peculiar and deep significance to the colonial housewife. Modern methods have done away with all this and to-day, the cellars of the few old houses that remain are more often receptacles for rubbish than aught else. So much the worse for the health of the household: so much the better for the lover of such old scraps as have escaped destruction. At least, I theorized in some such way. 
The oldest cellar I have recently explored was dug in 1708 and it is as empty as the head of the man who owns it. The next in order was dug in 1737-38 and is a dark cavernous retreat that chills the explorer immediately on entering it, so cold, clammy and musty is the air, or rather the dimly visible darkness that replaces normal atmosphere. Air or not, it is thick and so spidery that I recoiled at every forward step as the sheet-like webs touched me, and then, the muffled sounds were so suggestive of rats, bats and lurking vermin that had tunnelled under the thick walls from the outside world. On a summer day, it is hard to believe that such a place should be in the midst of light and gaiety. Here, Erebus, son of Chaos and brother of Nox, might feel at ease and take a mid-day nap in comfort, but no sane mortal is likely to follow in his footsteps. I go, not as a lover of darkness, but in a limited way, from a sense of duty, which is man's most disagreeable position in life. I am told I ought to explore that particular cellar and submit, assuming the rôle of explorer, much in the present fashion of that ilk, with modern improvements and taking care not to get nearer the real facts than comfort war- 


\section{Impressions}

rants. I am an ideal explorer, eager for unlimited glory and careful that no danger is run in acquiring it.

The anticipatory vision of rare furnishings, of pewter platters and brass candlesticks, of Canton china or a cow-skin trunk stuffed with pre-revolutionary documents; all the improbabilities are ranged in a long panoramic way. Enthusiasm is at flood-tide. The all-powerful arm, against which darkness struggled in vain, is a lantern, and mine is of the most approved pattern; but like the modern repeating rifle, it is possible to fail us at a critical moment, and the marshalled hosts of Pluto prevail against it. In a cellar, obstacles are excellent strategists and when the field appears open and marching unobstructed, the unexpected happens. It is no unusual experience of a life-time to have a lantern smashed and is the usual outcome of invading a colonial cellar. In this case I had taken but few steps when the feeble rays that merely accentuated the gloom, met an implacable foe. The glass that armored the flame was shattered; the flame itself succumbed and I, like Lord Ullin, "was left lamenting."

Helplessness is never pleasant. It magnifies 99 


\section{The Rambles of an Idler}

the evil designs of all that surrounds us and transforms friends to foes; but helplessness in the black colonial cellar is an exaggeration beyond language. We would delight in overhearing some people we know, when in such a fix. The mind flounders and has no use for common words. It is drowning, without the loss of breath and worse, not a movement is possible without collision. The implacable walls and immovable beams are loosened. One can stand rigid as a statue, so he thinks, but every beam proves a battering ram. Crouching is the only chance to escape annihilation and so, following what might be a solitary ray of light, as great a fool as myself to enter here, I sought the outer world.

Doubtless colonial treasure galore, I left behind me, bot there it may remain. Better to read what others have imagined of the good old days than seek for subterranean tangible evidences thereof; at least, it is wiser to wait until the house that covers it is removed and the blessed sunshine is your constant companion.

The recent excessive rainfalls covering many days have had such effect upon the forest trees 


\section{Impressions}

that many of them have an abundance of new leaves. The delicate light green and yellowish or golden green on the elms, beeches and oaks have all the effect of inflorescence and the woods as seen from my hill-top yard are beautiful beyond the ordinary leafiness of mid-summer. If mankind, more generally, would take a hint from this occasional phenomenon and deck themselves anew with the cheerfulness of youth, there would be brighter sunshine, in and out of doors.

Of far more importance to me than my neighbors is to learn the effect, if any, of this new foliage upon the birds. I cannot positively associate it with them as cause and effect, so far as their general activity and cheerfulness are concerned, for there is the question of coincidence; but this is the banner year for birds, so far as my records, since 1874, show. Never have there been so many individuals and all the nesting species have been represented. Today, July 22 , when ordinarily we must not expect much singing of birds, there is not a moment of silence. As I write-it is now mid-forenoon-not only the wrens, but the cardinal, song-sparrow, thrush, cat-bird, wood- 


\section{The Rambles of an Idler}

peewee and a white-eyed vireo are as vocal as ever in May; and now the question arises, whether or not the excessive moisture has not kept up the food supply and so the birds have their spring-tide vigor maintained. The summer, thus far, has not been an average one. Vegetation and bird-life have wandered from their time-worn paths. What the inter-relation, if any, let him who is curious, determine for himself.

Now that the trolley railway has cut my fields in twain, there has been opened up a new highway for birds, many kinds delighting in the poles, wires and the extended outlook. The more commonly noticed species are the robin, king-bird, indigo finch and blue-bird. They all sing or chatter constantly, and their united voices suggest the child's common exclamation over novelty: "Isn't this fun!" The cars passing at brief intervals do not disturb them much. They simply change their positions and continue their chattering as if never interrupted. It is comforting to know that the many changes of these recent years have not had the effect of driving away our birds. Again, the blessed blue-birds are a fixed fea102 


\section{Impressions}

ture. They were so some years ago, until their home, or headquarters, where they nested regularly and roosted nightly, was destroyed. They were as firmly established as poultry in the yard, or the English sparrows. It required no persistent observation to see them, daily; not more than to see the sky. Perhaps it will be so again. It is five months since they have come back. No sooner were the wires strung, than the birds accepted the situation. Drifting on the wandering gusts of March, they found here a haven of rest and since then, not for a day, have they forsaken it. Where these blue birds nested, I do not know, but many young birds appeared in due season. Electricity has done much for us of late, but nothing better, to my mind, than re-establishing the blue-birds.

Hot weather sounds are usually heard singly but, to-day, following so closely, there was no intervening moment of silence, were the cicada, the great crested fly-catcher, the cuckoo and the indigo bird. The first and last are the hottest sounds I know of. They mean summer to me as nothing else does. The fervent heat that sets the air over the fields all a-trembling; the 103 


\section{The Rambles of an Idler}

leaves that hang listlessly, pointing earthward; the grass that crackles under foot; the folded flowers awaiting the freshness of twilight-all these come to the front when I hear the cicada, our "'harvest fly," but not a fly of our harvesttime. They come after the grain is cut and the days have shortened by a full half hour. Like the leaf-cricket and the katy-did, cicadas are in place and accepted as a part of Nature's methods, but the indigo bird causes some surprise. It is a tropical bird in appearance and likewise in its tastes. When the mercury. is above one hundred in the open fields, it sings its loudest. It rejoices when men sulk and seek the shade, and is apt to be quiet on a rainy day. Myself in the shade, I watched one for exactly one hour. It left its perch only as a car passed and returned to it. In that time it sang without ceasing, except when on the wing. Truly, a hot-weather bird and from my point of view, a foolish one.

A little later, thistle finches drifted by. Pretty birds and yet a neighbor could see no more in them than that they were "the color of cup-custards." The curving twitter of their wavy flight is a hot-weather sound, but is com- 


\section{Impressions}

monly heard in winter also, when it seems quite in place. Theirs is an all-the-year-round song, but was of the heat, to-day, an intimate part and parcel.

Stepping aside but a few paces, I reached the brook with its overhanging willows, maples, wild cherry and an endless tangle of grape and green brier. Here there was, I think, a difference of twenty degrees in temperature. It was like entering an ice-house and what a delight to hear a tree-toad grumbling about the weather. I have been told that it was asking for rain and scolding because of too much of it; and again, that whichever way the wind blows, it always grumbles; but I accept none of these statements. I believe it to be grunting its satisfaction over its peculiar lot in life. Our common hop-toad has been sagely commented upon and been called a philosophical creature, but the tree-toad, comfortably settled in a damp nook of an old apple tree, has solved the problem of existence without vexation. His, it is, to contemplate the busy toilers that surround him and not wear out or rust out in so doing. There is the turtle in the mud of the meadow and the fish that dreamily floats where the cool spring water 
enters the creek; there are mole-crickets in the damp earth and the woodchuck in his deep burrow; all these are fairly fixed as to comfort, this warm weather, but all are liable to interruption, all require to exert themselves upon occasion; but with the tree-toad, it is one long day-dream, varied only with visions equally long at night. A tree-toad is an instance of embodied contemplation, of thought with a body that merely serves to anchor it.

Happily, no degree of enthusiasm as to $\mathrm{Na}$ ture stifles strictly human attributes. A walk in midsummer to be complete should have a happy ending. Its poetry should project itself into the prose of home-coming; but how best to accomplish this is an open question. My choice is to pass unobserved into the cellar and eat a fair-sized wedge of blackberry pie. It must be done dexterously. No one must know of what we are doing, and above all not one drop of tell-tale juice must be in evidence. It is a difflcult feat. There are few experts but I hold myself one of them, and yet it seldom happens that a curious expression is not noticed on others' faces as I re-appear. Life is less seri- 


\section{Impressions}

ous in the days of blackberry pie. To anticipate it, when amid-fields, however hot the day, is, of itself, refreshing.

Hearing its shrill call as I lingered under the oaks, I thought of other days when the Carolina wren is a more prominent feature of my hillside slope. Now, in July, its varied notes are tiresome, but later the exodus of the summer's songsters would be a serious matter if there were no birds to take their places and for a season, silence reigned where music had been the foremost feature of the day. Happily, with the passing of the thrush, there comes to mind the necessity of greater sociability on the part of this Carolina wren and our regrets that the rose-breast and oriole have left us are softened by the earnest comforter which whistles with startling emphasis: Why heed it? Why heed it?

It is well put. The wren offers to lead us into still pleasant places. Our summer friends will come again, but while away, it is not disloyalty to make new ones. Our wren is a bird of all the year, but never seen or heard to so great an advantage as when, to men's eyes, the 
outlook is dreariest. Never the day so dismal that there is no redeeming feature. The voice of a bird above the roar of the tempest bears a weightier message than many a cherished proverb. Nature does not waste words with us. There is abundant reason for so doing when the Carolina wren sends this cheerful query ringing through the woods: Why heed its Why heed it? Though the impenetrable clouds droop earthward until upland and meadow are covered as with a pall; though there be but dripping branches and sodden grass, and the air chilling, as we breathe it, until we shudder and long for the cheerful glow of the fire-side, why heed it? Destruction is not being dealt out to us. The world is worth a visit, even at such a time, or why the unsheltered wren so cheerful? The meaning of its words will be made plain, if we walk yet a little farther into the fields. There still remain, even in February, a red berry and a green leaf.

I interpret the wren's enthusiasm to thankfulness that trifles remain, and a word here as to Nature's trifles. Are we so very wise that a single leaf can be overlooked or a red berry be disregarded? Tell me, first, why any leaf is 108 


\section{Impressions}

still green and how this berry has escaped destruction? To grow wildly ecstatic over a summer landscape is not evidence of erudition equal to its comprehension. The flood-tide of Nature's activities may well bewilder us, but not so the trifle of a frost-defying bit of sod, with a green leaf, or even a blossom. The wren that discovers this has cause for rejoicing, and if the elements are rude and Winter blusters in his surliest mood, that bird is blessed who from its heart can shout, Why heed it? why heed it?

I have braved many a winter storm that I might hear some bird of the season. Encouraged by the good-natured bantering of this wren, I have not heeded the discomforts of keen winds or driving snow, but sought those sheltered nooks where I knew the birds had gathered, and never have they turned their backs upon me. When Nature's guest, I am happy.

"He knows what's what!" remarked my companion. "Does he?-indeed!" I exclaimed, with mock astonishment, adding: "Then he's the greatest curiosity on earth!"'

I have learned to be careful how I pin my 109 


\section{The Rambles of an Idler}

faith on the extraordinarily learned; for, occasionally, it has proved that, like the unco' good, they fail us when we least expect it. This feeling has no reference to learning or goodness per se; but the fallibility of humanity must never be a forgotten factor. Knowledge in excess of our own magnifies its possessor; and we measure his strength by the exaggerated outlines of this supposed giant. But, when the hour of test comes, and, eager to profit by reason of his superior knowledge, we are all expectation, how grievously disappointed we may find ourselves at its close-if not long before the interview is ended!

Geologists are given to coming this way, at times, and, with a majestic sweep of the hand and piercing glance of the eye, tell us, in terms too clear to be misconstrued, what we already know; or else inform us, with scarcely less emphasis, what we know to be not true. It may be easy to read the riddle of the rocks; but here we have only sand and gravel, and of the floods and local cataclysms that arranged and re-arranged it all, and the intervening periods of quiescence when the sun baked the mud, and, again reduced it to sand and water, perhaps 


\section{Impressions}

giving weeds a chance to grow, we know very little.

One prominently outstanding fact is that attempted histories, as yet, are continually contradicted, as we see new exposures of the various deposits. They are to be accepted as of no greater value than that of being suggestive. We can gather useful hints from the literature of the subject, but little else. Yet, not an author but has laid down the "facts" as a judge does the law-that thus-and-so was the sequence of events from the fierce arctic conditions of the glacial period to the present day. This is not too strong a statement; for each geologist, as he comes, contradicts his predecessor, leaving the poor layman, as he grows older, to find only confusion steadily worse confounded. Can it be, as in some other occupations in this life, geologists are at their best when not discussing geological subjects?

By actual count, taking notes of what was said in the field at the time, in their presence, I find that eleven men have expressed sixteen opinions-five of them strongly inclined to their favorite explanation, but adding: "Or. it might have been that___" 
Fatal words! Yes: "It might have been"that Nature pursued the plan that she does today, and these things that are such a puzzle are susceptible of a simple explanation. It might have been that the cold weather became Springlike, and the raging torrent became an ordinary freshet, and sand instead of rocks came down the valley, and, when there was not enough water to fill this valley to the brim, it flowed at a lower level, until, as at this writing, we can almost cross the river, dry-shod, jumping a little, here-and-there. The simplest explanation is the best in the long run for laymen; and this plunging of the earth's surface into ocean's depths and uplifting it to the mountain's top is too much of a tax upon the non-scientific mind. It is, at best, a bold assumption, to print which gets the bewildered geologist out of an ugly fix.

However, there is something very attractive in the geologist's "it might have been." It affords, as naught else can, a graceful back-door through which to disappear as theories become untenable. Since the glacial period was first discussed, this back-door has never been locked. When it is, the lavman can accept statements with confidence-but not until then. When 


\section{Impressions}

the back-door is locked; when geologists cease to contradict;

When, open-eyed, we see, from Heaven's height

The earth where long we groped in darkness drear,

Then and there only, banished is the night;

Suggestion vague turned to conception clear!

Geologists are not the only queer people we meet. There is a pseudo-scientific clique that appropriates the title of "archaeologist," and asks us to believe a great deal more than the meagre facts warrant. These men all know what's what when specimens are produced, and spin marvelous yarns concerning every odd shape of worked stone. The jagged edge of a chipped stone is always a saw; and the iron in any stone implement, reddening, by oxidation its surface, is always a blood-stain. The simplest scratches on a clay bowl are claimed to be of marvelous significance. The question arises: Would the old-time Indians recognize themselves could they read the papers read at archaeological conventions?

There is always something impressive in seeing objects that are very old. To hold even so simple a thing as an arrow-point and consider 


\section{The Rambles of an Idler}

its certain history, its Indian origin, its evident purpose, and what might have been its career ages ago, always arouses in us a degree of interest that is pleasurable; and this increases as evidence of antiquity is brought before us. Yet, the enthusiasm of the archaeologist, leading to endless extravagances and fantastic theory, is persistently contradictory the moment the maximum degree of antiquity is mentioned. When man first appeared on the American continent, possibly we may never know; but that evidence which makes his antiquity a geological question is abundant and no less unmistakable than the traces supposedly indicative of his subsequent career. If geologists are timid, archaeologists are overbold; and the lack of information from the former and the clack of the latter leave us ignorant where we would be wise, and doubtful if either really knows "what's what" even when he sees it.

The botanist and entomologist are the only specialists we have met, of late, who speak unhesitatingly. Flowers and butterflies, trees and the beetles that bore into them, are unmistakable. We know an oak or an elm, when we see them; and their respective insect-foes are 


\section{Impressions}

readily recognized. This is a comfort greater than the uninitiated suspect. Specialists who are afraid to speak, and keep the "back-door" ever open, are the greatest bores on earth. It is a trifle discouraging to find ourselves, at this late day, still in the dark concerning the commoner forms of life. The man who knows what's what, and will throw light over it all, has not yet appeared upon the scene. However diligently we study and finally convince ourselves that we are right, there is always a specialist crossing our path and assuring us we are wrong; and another in his tracks, agreeing only that the poor layman is wrong, but placing his error on a different basis.

If happiness depended upon the exactitude of our knowledge, then, indeed, would we be miserable!

During the past year I removed each morning from a calendar the slip of paper bearing the previous day's date, and upon which was a quotation. At the year's close I had read 365 brief selections from a modern author's works, and was forced to the unwelcome conclusion that fully three hundred of the whole 


\section{The Rambles of an Idler}

were echoes of writers who had lived and died anywhere from five thousand years to a century ago. In short, I had been treated not so much to the author's "works" as to his stealingsor, more politely, his unconscious appropriation of others' thoughts.

The above is not an extravagant statement. Early in Jannary it occurred to me that the quotations for each day had a familiar ring, and I was surprised to find how our modern author suffered when put to the test of heartless parallels.

That the same idea should arise, even when men and manners have radically changed, need not excite surprise. The ocean or a mountain range, a shipwreck or a more commonplace incident, may similarly impress two or more witnesses who recount it; but the ear-mark of originality will, in each case, be there. Mere similarity of thought is not to be mistaken for the blundering reproduction of a master's words, or the careless adaptation of a familiar thought. The brief comment on a passing occurrence, a flash of wit, or a description in a few words of a sunset or the sea, born in the brain of greatness, stands for all time as the 


\section{Impressions}

perfection of word-painting. To change its setting is to mar its beauty.

From whom Job and Jeremiah, Solomon and the author of "Ecclesiastes" quoted-if they did quote-probably no one will ever know; but later literati have quoted them, and they have, in turn, been quoted, with such changes in each case as gave the latest version the appearance of a new-born thought. The original version and the latest may be widely different in form; but there is-unfortunately for most claimants to originality-an unbroken series of versions in literature, from dim antiquity until to-day.

A large proportion of the good things now offered are cunningly adapted appropriations, and he appears to be the most successful " author" who most skillfully conceals the sources of his material. The reason is not hard to find. The literary man is too much concerned with books and too little with the fountain-head of inspiration-Nature.

Books that are the outgrowth of older books may have their place, and poems that tell the same story greater poets have already told may please the reader; but is it quite fair to 


\section{The Rambles of an Idler}

the memory of the truly great of other ages that the truth should be suppressed? The fact is indisputable that the century just closed has given the world but very little originality. If this blessed quality is exhausted, then let the fact be candidly admitted; and, instead of new "authors," let us have new "adapters." New versions of old stories printed as such will be so far welcome as possibly to warrant their publication; but let us not hail as an originator one who has no originality. However smooth the prose or liquid the verse, correct the rhyme and accurate the metre, if the idea clothed in a new suit of words is an old idea, let it be so heralded.

If this severe but just measure is applied by the historian to the writers of the past century, those truly original are quickly named. Perhaps, we have had a million books in the last one hundred years, but, have we had a thousand genuinely-new ideas? Have we had a hundred?

Place modern literature in another light, and see how far it has added new words or phrases to our speech. For long we have had Homeric, Virgilic, and Aristotelian; Dantesque, Shakes- 


\section{Impressions}

pearean, and Darwinian. Probably, a few more names might properly be used to mark an epoch. Here, in America, we have Emersonian. These are words necessity has coined. They were called for because originality had asserted itself. Only with them can we make ourselves readily intelligible.

The world has not been lazy in science; and we are fairly stunned by the magnificent achievements made in endless directions. The triumphs of engineering skill in building cities and bridging rivers, and the grand results of biological research, leaving the mind no longer groveling in ignorance as to the problems of life's origin and destiny, are sufficient to show what has been done in other phases of human activity; but nothing in like exultant strain can be said of literature. It is, at best-save here and there, a sadly-lonely page-an echo of an echo that, repeated and re-repeated, has come down, century after century. It has only been necessary to tell an old story, with trifling change, to gain the world's plaudits, and be called an "author."

If this be recognized as a valid oriticism, and an honest desire for originality be created, 


\section{The Rambles of an Idler}

whither must the aspiring writer go? Surely, not to the library. Hindrances only will be there. A new book-new in every senseshould be conceived, if not written, where books are never seen, but wherever the stern realities of life are all-absorbing-amid bustling activity and the fiercer struggles for bare existence; or in green fields, where Nature holds sway and is never idle; or on a mountain-top, where freshest breezes blow; or deep down in the valley, where trickling waters are wearing away the rocks; anywhere that books are not, the breath of life may enter into an honest thought -an actually-new creation!

What constitutes a new idea is as evident as the fraud of old ones set-up as new is patent. It is something not previously thought-a new combination of familiar facts giving in their association a strictly novel impression. Such ideas occasionally burst upon the world in the past century, and are to be remembered with its notable meteors and comets.

As the. race of writers is likely not to grow less, the effort for their betterment should be very earnest; but whether such effort will ever be made is problematical. Unfortunately, 


\section{Impressions}

those who read are not sufficiently exacting. It is an open question whether originality is as much desired as it should be.

This is a grave charge against our intellectual status; but it would seem as if the settingforth of matter in a manner even suggestive of originality is banned by the majority of critics. The greater the earnestness of an author, the greater his condemnation. The modern reader does not wish to be forced to think. Familiar with certain conditions, his mind is gently stirred to mild activity as the leaves of the last new book are turned. It is exertion enough to smile at the wit that lost its freshness a thousand years ago; but an outburst of novelty would command close attention, a knitting of the eyebrows, a sharp exclamation of dissent, or applause more vigorous than an approving nod. No-no! That would never do! Ease of mind or of body is too delightful to be disturbed. Cling, rather, to the inapplicable proverbs of Solomon than have the memory taxed with new ones better fitted to our own day.

Judging from the undoubted skill of many of our most prominent writers, the power to pro- 
duce novelty has not been lacking, but allowed to lie dormant; or fear has entered the mind, and really-new creations have been shunned because of a vague feeling-or, perhaps, an unmistakable one-that the public might not approve. And this same public must be considered.

Such impressions and such argument are fatal drawbacks to aspiring authorship. Its message should go forth to the world, whether it likes it or not. Of all bugbears, the public takes the lead; and consideration of a bugbear is fatal to a literary career. So large an entity as the public has no fixed opinion. "Vox populi" is nothing but noise. This public is continually falling to pieces because of its lack of cohesion; and the detached masses are readily kicked about by the cunning, and finally licked into respectable shape by the conscientious. No author should expect to reach the millions, but hundreds scattered through them; and they, it may be, will carry the message-surely will, if it be a worthy one-to their fellows.

The author who clothes in fitting words one great thought is nobler than he who re-clothes a hundred familiar and, often, out-worn ideas! 


\section{Impressions}

Diluted Homer, Virgil, Horace, those

Who framed a worthy song; who sang like men -

A weak solution of majestic prose

And mightier verse from Shakespęare's magic pen Faint echo of the songs that poets writ

When Byron flashed like meteor in the sky -

The ghastly relic of a noble wit -

Such modern poetry is, alas! And why?

Is there no story worth the telling left?

Must rhythm never leave the time-worn rut?

Are we of novel thought and deed bereft,

No unsealed mountain from our outlook jut,

O'er which to clamber, giving view unthought

Of this wide world? Or, is all commonplace?

To a dead level human action brought,

Outworn, old Earth; exhausted time and space? 


\section{The Rambles of an Idler}

duce novelty has not been lacking, but allowed to lie dormant; or fear has entered the mind, and really-new creations have been shunned because of a vague feeling-or, perhaps, an unmistakable one-that the public might not approve. And this same public must be considered.

Such impressions and such argument are fatal drawbacks to aspiring authorship. Its message should go forth to the world, whether it likes it or not. Of all bugbears, the public takes the lead; and consideration of a bugbear is fatal to a literary career. So large an entity as the public has no fixed opinion. "Vox populi" is nothing but noise. This public is continually falling to pieces because of its lack of cohesion; and the detached masses are readily kicked about by the cunning, and finally licked into respectable shape by the conscientious. No author should expect to reach the millions, but hundreds scattered through them; and they, it may be, will carry the message-surely will, if it be a worthy one-to their fellows.

The author who clothes in fitting words one great thought is nobler than he who re-clothes a hundred familiar and, often, out-worn ideas! 
interpreted and if so, the question arises, How far have we wandered from the facts?

While yet the crow was in sight, a Carolina wren rushed from nowhere into visible space. It came to view, like a flash of lightning, but unlike the flash, remained. All this of its own volition, is my assumption, but other causes may have operated. We assume the bird to be a free-agent-no such condition ever existedand theorize accordingly. Tarrying on a bare twig, the wren sings Mer-ri-lee, over and over again. No other wren replies; no birds of other species pay attention; we conclude that it is singing for its own satisfaction. Do we know? Is a word of what I have written, in any sense, correct interpretation? Yet, conscious of our inability to fathom the impulse of a passing bird, if we weave no net to cast over every crow and wren we meet, the interest in such interviews would vanish. It was only a crow and a wren at this early hour, but they filled the landscape as completely as a flock of either might have done. Every mesh of the net I had woven was a pleasing thought, and casting it about the birds, I was also entangled. Irresponsible thought, not a soulless realiza125 
tion of truth, possessed me. It is often so, and we place too high a value on such idle thinking. It ever poses as something it is not.

The crow swerved from the straight line of its flight and circled over the water; the wren never ceased its singing. Why? If we are moved continually to ask questions, a very little will shut from view the world as a whole, and if long puzzled by a minor detail, what of Earth's entirety? The naturalist goes forth in confidence to explain away obscurities, to let light into the dark places, to bring all things easily within our grasp. Does he? Few indeed are the interpretations to which the whole world assents. Who has proved that the wren is singing for its own entertainment? Why is the crow circling above the flooded meadow? Is not my "breakfast" theory all moonshine? A library is ten thousand assertions and twice ten thousand contradictions.

We must not take Nature or our views of it too seriously. They are excellent in their proper place and a source of sorrow out of it. To interpret what we see is a mighty task, under which Titanic shoulders bend, but to weave a few fancies fits the passing day and 
the average mortal. Philosophers are few and far between. We can look at them as we do mountains in the distance. They fill a place in our outlook but we need not mope because they are inaccessible. Be king in the kingdom of your own mind, and not attempting the impossible, happiness is assured.

I looked upon the crow and the wren as my friends, but they looked on me as an enemy. To disabuse them of a wrong impression was not possible, so I was at every disadvantage. I hailed them as comrades and they shouted back, "You lie!"' A nice condition of affairs, truly, but what was I to do? Go home and mope? No; I will at least "make believe" they are friendly and have as good a time as possible. Go in that spirit and a pleasant and profitable outing is assured.

Crows represent the more serious aspects of Nature; the wren stands for Nature when she relapses and mirth is uppermost. The misfortune of the crow is that it is common. If seldom in evidence every quality would shine with unwonted lustre; indeed, if we followed the literary naturalist, every crow would be a raven and the commonplace $c a w$ be an ominous croak. 


\section{The Rambles of an Idler}

Quoth the raven, "Nevermore,"' and how weird and uncanny is this lover of "Night's Plutonian shore;" but caws the crow, "Evermore". and alas! we simply grow tired of the iteration. So much, for indolent interpretation, but if judged more justly, the vocabulary of the crow would rouse as much interest as has the raven's. The old story: more wonderful matter in the home valley than in all the mountains beyond; but because they are beyond, the mountains are veritable treasures of all we can desire. The mysterious unknown enslaves us; that which is familiar, we despise. Ever longing for the impracticable raven and indifferent to crows. But honors are easy; the crows despise us and with good reason. There is seldom a man who is as cunning as they are.

A hundred of these fine birds have come inland from the river. The familiar meadows are now an unfamiliar lake and how they chatter over the new conditions! A clamor has arisen that drowns the minor voices of the awakening world. It is the last day of February and a south-east wind is blowing. Do the crows know that it is the last day of nominal winter? Whether they keep a record of the 


\section{Interpretations}

years or not, they act as record-keepers for him who loves an outing. The warm wind, the excited birds, the softer tone in the tall pinetree's top; only now the velvet glove and no suspicion of the iron hand. The crows interpret the significance of the day and I take my cue from them. An unwise interpretation and a lowering of man to a bird's level, it is asserted, but the day is more attractive because of it all. It is the part of wisdom to play the fool upon occasion, if doing as I have done, is to play the fool.

I love the cawing of the crow because it gives rise to reminiscence. The cries of this bird were a childish wonder more than half a century ago. I strove even then to encompass their meaning and from that day until now, and the half century gone, I am still in the dark. Corvine literature covers many. pages. As a whole, it reminds me of the mocker nut. There is an almost unbreakable shell and supposedly a kernel of the sweetest meat. As yet, only my fingers have been cut by the jagged edges of the broken cover. It is but a step, happily, from the book to the bird. I say, happily, for it is from darkness unto light. Under the open sky, 


\section{The Rambles of an Idler}

into the fresh air, cheered by the swelling leafbuds, stimulated by the odor of the juicy turf and by sight of that first fruit of the promised spring, skunk cabbage, gorgeously arrayed. These are the belongings, so to speak, of the cawing of the crow. The long, dreary winter through, the crow has hinted of them, and now there is exultation over the hint made good. There may be rugged winter yet for three more weeks. The almanac promises that, but the crows rise above such soulless mathematics and declare it is spring now. Liars, every one of them, but what of that? Are their feathers black because of this grievous fault? We would miss much if we did not occasionally deceive ourselves. The Winter that is yet lying in wait for the poor rambler can have his full swing and welcome, when he can get it. I, for one, will not complain, but to-day the south wind holds him back and I will have my innings. There is a suggestion of the new order and with so slight a tool as this I will build a castle that will last me for the passing hour. If a day-dream is so vivid that it has all the charm of reality, pray, what value over it, has the reality? I am as happy as the crows about 


\section{Interpretations}

me and that is ample for my needs and, strange enough in this world, it reaches to the outerbounds of my desires. I am happy, too, because the crows are and so I hail them as my friends. It is true, they will not-interpret aright my meaning, but this shall not cast a shadow over my sun-bright sky.

All the while, the quick wren has been singing. Quickened unto a fuller life than any man can lead, the wren is my leader and I fall behind it so far that I am not in strict sense a follower. Mer-ri-lee, Mer-ri-lee, Mer-ri-lee! Three times over and never with a lack of energy, though now it has been singing for full five minutes. That is a longer period in the wren's calculations than twelve times five in ours. The eye can follow when the body cannot, and now that I force the bird to quit its perch, it is marvellous to see what a range of country it covers in a brief moment. From tree to tree, down to the ground in a tangle of smilax and up to the peak of the barn roof. Through the cavernous old mows and out at a knot-hole and back again to its starting point, and all the while declaring itself to be taking life Mer-ri-lee, Mer-ri-lee, Mer-ri-leel 


\section{The Rambles of an Idler}

I wonder when this strange bird stops to feed and if it retires at an early hour after so active a day, but to attempt to solve any problem of wren-dom is vain. My interpretation may be wide of the mark, but it soothes my vanity, which is sufficient excuse for its being. I must reach to some conclusion. Failing in that is to go mad. Whether early to bed or not, the wren is an-early riser. Long before my own inclinations to be abroad have shaped themselves, the wren is all too apt to be just outside my window, shouting, in energetic tones, the merits of the morning.

I confess to weariness of the flesh, at times, and latterly, have seen paths too rugged for my feet. The wren therefore does not appeal to me as did the crows. They are too quick for my sluggish pulse and all I would know of them is beyond my interpretative power. I can but translate their song of this morning as Mer-ri-lee! and if I saw aright, their actions fitted the word.

The morning wears away and I am ready to return. There is yet much to be done, digesting my impressions. Were they greater in number, I might lose the spirit of them all. It 


\section{Interpretations}

is far easier to see too much than too little. The lack of mad-cap, feverish adventure has not occurred to me. The day seemed full, and what seems, is, in the chop-logic of an idle rambler. I cannot worry over the niceties of language and the proprieties of thought. Nature is intelligible without them, or we think it so, which equally meets our purpose. What the crows and the wren are to Nature is one thing; what they were to me, is quite another. I may have misread, but that did not harm them. They certainly misinterpreted me, but I was not cast down. The truth would scarcely have made the day better. Crows, wren, rambler; all were happy. For each and all the world was as it_should be. I have never known better birds, nor have I aspirations. Blessèd are the poor who have no rich relations. They escape the pangs of the envious.

As I find it set down in the almanac, Spring commences at $8: 16 \mathrm{~A}$. M. this twenty-first day of March, and at the proper tick of the clock, I put my best foot forward to see what is or has been the initial movement in Nature, but all to no use. That magic moment was a matter of the 


\section{The Rambles of an Idler}

sun, moon, stars, perhaps the milky way and a vagrant comet, but not a sign on this old Earth, which of all the bodies pitching headlong through space alone concerns me.

It is very kind of almanac-authors to tell us just when spring commences. I know of no pleasanter reading in the depth of winter. If I take down the pamphlet from its brass hook on the mantel to see when the moon changes I always turn also to this delightful date and let fancy indulge in sky-larking. So doing, brightens many an otherwise dull winter day.

For many a week I have been looking forward, and now here among the old oaks, with meadows before me and the distant hills but dimly outlined, I am in the actual presence of an instant set aside for peculiar honors. No, I am not. It was 8:16 A. M. five minutes ago and the commencement of spring has passed into the progress of the blessèd season. Small progress yet but many have been the preparations, and these may very properly and profitably concern us. I had already interpreted many. The little hylodes and the hylas have been making the air tremble over the marshes since the eleventh, and as if that were too little to command at134 


\section{Interpretations}

tention, robins, blue-birds, song-sparrows, the cardinal, Carolina wren and crested tit have not been quiet except after sunset and not always then, and an hour before sunrise every one is up, about and tuneful. Killdee plover, too, have been trooping over the house and whether or not they had a message for me, I heard their clear whistle and interpreted it as a hint to be as wide-awake as every bird about me.

There were other birds, to say nothing of crows, hawks and blue-jays, but let that pass. The day's incidents are major and minor and the former claim our attention; perhaps too closely, for not always the loudest noise is fullest of suggestion. The quiet remark of a thoughtful man may be weightier than the clamor of a thoughtless crowd. Because it is the custom to be guarded in assertion, I suggested the probability mechanically. So much for being a slave to custom. The truth is, the clamor of a crowd has as little import as the steady hum of children"s voices when at play. Boys shout when they rush from school. It is the expression of pent-up energy and addressed to no one. I think not one boy in a hundred is aware that he has shouted. So with the clamor 
of an excited crowd. One calm man that knows the secret of it all can hush a multitude by a wave of the hand. This is one of the much talked of "eternal verities," rarest of entities in this world, but innumerable are the quips and oddities that masquerade in their old clothes.

Is it safe to interpret the grand volume of song and sound that seems to shake the earth in some such contemptuous manner? It is not an uncommon setting-forth of its significance, for Nature has not always been fairly dealt with. I liken all I now hear to the steady hum of industry when men are at work.

The world is now very busy; that out-door world, I mean, which is blessedly non-human, where two and two make four and sophistry is never dreamed of. Nature's abiding-place. Where creature looks creature in the face and whether it is peace or war, there is no lying about it. The permanent residence of His Majesty, the Truth.

What I would know is what in place of an almanac has wild-life to guide it? Wild-life, per force of habit of expression; superlatively rational life in fact, another of the world's "eternal verities." 
Neither bird nor beast is weather-wise beyond possibility of disaster, yet I believe statistics, if obtainable, would show they are ahead of the lords of creation, or, more correctly speaking, the climax of evolution. Every bird has taken upon itself, to-day, to proclaim the opening of spring, if I interpret them aright, but whence their knowledge? They have foreseen it all too and what little can we imagine of their mental process! It may be said that the frost is out of the ground and the sun-warmth has been sufficient to rouse the frogs from their lethargic sleep, but this apparently reasonable explanation falls short. The frog that slept grew while it was sleeping and has energies now which it had not when the initial frosts of autumn sent it to cover. Sleep is not so near to stagnation as has been held. It is still less like death. Every bird, too, that weathered the winter stands in a new light. Not one is its old self and what is the hieroglyphic on rock or tree that it has deciphered? I can read the almanac and put on a knowing air at will, but to what authority does the song-sparrow refer? I do not see them scanning the freshening moss or gathering about skunk cabbage and discussing the gold 
and bronze and purple of its anticipatory growth. Perhaps the birds have noticed that the daffodils are above ground but I for one am not sure and I pin no faith on the assertions of those who are unqualifiedly positive. I will not deny that every frog and bird, this eventful day, is wiser than Solomon as to weather, season and all that is to be, but I am not. There have been too many snow storms in April that I cannot forget, and a snow-drift in May through which I wallowed to pick dog-wood blossoms. Man's memory as to the past makes him conjectural as to the future and there it ends with him, but every bird, this morning, poses as a prophet. So, at least, I interpret each and all of them. In such light they are the more companionable and that means much. There is a vast deal of satisfaction to be derived from ignorance or misinterpretation, when mathematical demonstration is impracticable. I am not necessarily unhappy because Nature may be making a fool of me. I take what seems to me to be a rational view of what is going on. We have but to clothe with plausibility any outcome of the imagination and it will pass for a fact. All that we need to remember is that the future may 


\section{Interpretations}

strip it of its garb. This the inevitable result of our imperfection as interpreters, and he who is quickest to unlearn becomes at last the most learned. It is not more necessary to acquire facts than to unload false impressions. The weak view that it reflects upon our intelligence to admit that we have been misled is ever a prominent obstacle in the pathway to a right understanding.

This is March 21st and with a full appreciation of the conditions that now are, here I find myself at the parting of the ways. I hope for, indeed, rather confidently believe and plan according to what I think is before me, and all is based upon experience. But not a bird or a frog that gives heed to a recollection of another year, if it has one; yet every one of these creatures is equally confident with myself as to that which is approaching. The power that tells them denies me the same knowledge. So far only am I confident. This then the difference between human and non-human life, and it is a wide one; but seen in another light, we are not so far apart. I am hopeful of fair weather, abundant sunshine and budding trees. They are sure of it. Other possibilities never occur 


\section{The Rambles of an Idler}

to them and, we may, all of us, be bitterly disappointed. Spring commenced at 8:16 A. M., March 21st, it is true, but winter does not always die nor even abdicate on this same day. It is not succession: Winter is dead! Long live the Spring! but a struggle for place and power with the immediate outcome exasperatingly in doubt at times, however certain the ultimate result. Less than a century ago we had ice every, month in the year.

Doubt is not altogether an unknown quantity in animal mind, but it centres on objects rather than generalities. Snakes are always chary about haste in this matter of sunshine usurping the time-honored seat of frost. Perhaps some unexpected turn of affairs resulted in the prematurely turning out of the big, sleepy water snake before me. On a mat of dry dead grass, sheltered from the wind and in unobstructed sunshine, it is the picture of comfort. It is true that, of all our serpents, this is the earliest species astir, and ready, I am told, to dine off a sucker when the latter lumpish fish crowd the tide-full ditches at this time of year. The particular snake before me is so tightly coiled that it covers scarcely more space than grand- 


\section{Interpretations}

father's old pewter dinner plates, but I see it is heaped up in the middle so as to form a low cone rather than a flat coil. Shaped like a generous mince pie such as hungry boys, in late years, attribute to indulgent grandmothers, particularly when the maternal product is wisely, more sparingly, dealt out. Of course it will occur to everyone that it is a long call from snakes to pie, but herein is the teasing and yet charm of out-door meditations. No one object can fix our attention long, and imagination always travels in seven league boots.

I was sorry to disturb his snake-ship, but the demands of curiosity are imperious. Prodding the reptile gently, it slowly straightened out, but made no protest as any summer snake would do. As the coils relaxed, a thin covering of mud on the scales cracked and fell away in little flakes. Again I thought of grandmother's pie-crust and its precious crumbs. The snake glided away with that minimum exertion of effort that suggests it has but to will to move and lo! it is accomplished. This extra-early water-snake was no "ophidian acrobat" as is one other species common here, but showed not a trace of sluggishness when forced to move. It was free as 


\section{The Rambles of an Idler.}

the birds above it and now again in the warm mud of the ditch-out of sight, out of mindI turn once more to the birds. I would I could always tell which song of the morning is the key-note of the day. It is a matter of more importance than many may believe. The pee-wee is abroad and were its mournful note taken as your cue, the day would be less exuberant and enthusiasm be repressed. There are days when the pee-wee is their best historian-languid August days for instance, when exertion means great labor for a slight return-but not to-day. This is March 21st, the birthday of Action; here, on this particular dot on the earth's surface, the true New Year's day. The day of Nature's own appointment and the real day still. Man's interference results in an illogical almanac, but the facts are unaltered. The new season is here. The cardinal proclaimed it. It will be crowned later, when the violets are in bloom. The cardinal proclaimed it and the polyglot wren took up and re-told the story with added energy, and the blue-bird whispered the secret in the silent woods, and the robins shouted it abroad after the world knew all about it. I accept the whistle of the cardinal as the key-note 


\section{Interpretations}

of the day. Joy, energy and hope are writ with cloud-built letters across the sky. Great white marble masses, fresh from the quarry and unstained, set in the clear blue that stands for truth. See it! See it! See it! Jolly, jolly, jolly! jolly! whistles the cardinal till all the sleepy world is wide awake.

What a greeting on this auspici $\mathrm{s}$ date!

Early spring flowers bloom nowhere so profusely as on a poet's pages, but I propose this April morning to go to the meadows-to the part where the bluff that faces them is sheltered from the wind. A single spring beauty, upon which my eye falls, so pale that the thought of color belonging to it never occurs to you, it seems to me expresses in its name more than all that can be said of it, however neatly shaped and truly rhymed the stanzas. It is always something to stand in the actual presence. Afterwards we can better measure the value of the traveller's pages; aye, and the poet's also. It sometimes happens that the full significance of a poet's line is realized. Violets make azure the sod until it seems a mirror reflecting the sky; that is, they sometimes do, but the trouble 
is, once having seen the statement made, we are ever expecting such a pretty sight and never contented with a single blossom. A better plan is to take up kindly with a solitary flower and consider what it stands for; seeing therein the whole of summer and the fruits of autumn, perhaps peering into futurity as far as the repose of winter. This is no labor such as only the philosopher is equal to; to exercise such faculties within humbler scope is the most worthy purpose of an outing. Muscles can be kept limber in a gymnasium but muscles and mind coöperate only in the open air.

"A little child shall lead them." Be led by a violet and you will dance through life, tripping it lightly over the roughest ground.

I read recently that a new species of violet had been discovered some hundred miles to the north of us, but why stand astonished over the announcement when the blue and white and purple bloom of the door-yard has not yet appealed to us as it should? It is wonderland wherever we happen to be ignorant, which is the usual condition, and a wonderful land in proportion as our eyes are open. Whether shut or open is our own affair. 


\section{Interpretations}

Ask a violet any reasonable question and it will give you an intelligible reply. If we stand amid ten thousand, we may be lost in astonishment at their numbers and forget the knowledge the individual blossom would have imparted. A violet in March or earlier, heralding the millions that are coming is the one chosen of its kind to interpret for me what is their place in Nature. It does not tell all its story. No object does that. This is well. If there were not still one more question to be asked, a powerful incentive to be under the sky, instead of under a roof, would be wanting. The big trees of transcontinental regions and the trackless forests of the antipodal world may excite our admiration, but not to the extent of impatience if we are kept at home. Even here, where it is said the world is about worn out, there remains many a mystery. Worn out, indeed! South Jersey still has nearly two million acres of woodland. There is comfort in the thought even if we never see them.

That is a pretty story of so long ago as $\mathbf{1 6 9 6}$ when Anne, a bride, just before entering her new home, plucked a tiny flower from the sod 


\section{The Rambles of an Idler}

and holding it up to John, said, "Heart's ease."

Tradition is silent as to John's reply but I do know that forty-three years and three months passed before the tie was broken. Heart's ease meant much, then, in 1696, and now, in 1905, it means much to me, a descendant of these sturdy folk who solved the problem of life so significantly. No wonder; they faced a new country where novelty ruled and roused excitement to its highest healthy pitch; when every day meant much and success went forward by leaps and bounds.

A new country then, and an old country now. Four generations, 'twixt them and myself, have done a deal of mischief from my point of view -have wonderfully improved matters from others" standpoints. Now, my neighbors are singing, "Hail! Columbia, Happy Land," while I murmur, "Hail! Columbia, Virgin Soil!" and think of the white woodland violet of other days and rejoice to know there are a few trees left that sheltered them and now are sheltering me.

These early spring days provoke to a reminiscential mood. The rattle of the little frogs in pools and the marsh, now low, now louder, 


\section{Interpretations}

as the wind carries the sound away or bears it toward me, is monotonous. A single, scarcely varying hum is soothing rather than exciting. We dream rather than think, under its influence, and the thought of those gone before is apt to be a controlling one: Where are they now?

With eyes as eager, songht the signs of spring,

With ears as willing, heard each note that fell

Where ardent songsters made the valleys ring

With lover-notes that cast such potent spell;

Theirs the same hopes; theirs, youth's unburdened brow;

Life's earnost purpose theirs; where are they now?

Alone, I linger where their busy feet

Pressed, in life's urgent quest, the yielding sod;

The self-same stream and leafy wood, I greet;

No path of their's I have not often trod.

Sunshine and shade; gaunt oak and beechen bough, They knew them well as I; where are they now?

Where are they now? Give heed to happy song,

To every soothing, whispering breeze attend;

Where sunbeams woo them, hear the merry throng;

Proclaiming blessèd hope, their voices blend.

Here in the wild wood, by the winding stream,

Their message reaches me - so doth it seem. 


\section{The Rambles of an Idler}

There is likely to be something radically wrong if you do not find your own thoughts sufficient company. To alter a familiar saying, converting it into sound sense, "one is company and two's a crowd." Of course I mean to apply this only to an educating stroll. When the tongue is busy, the eyes are likely to take rest. We may see, but only blurred images, if all the while we are discussing that which is foreign to the place. Better, when you stand where flowers grow, to be one with them. Let the bird's song make a bird of you and not merely a-half-hearted listener. Whole-heartedness is absolutely required. Then the outdoor world is a new one, and though you may not have gone a dozen rods from your doorstep, when you return it is as a traveller from far distant lands.

"I love not man the less, but Nature more." An honest thought in every rambler's breast. Then, too, there are people and people. $\mathrm{He}$ who considers his own welfare and comfort must draw sundry distinctions.

A spring poet has no rights that editors are bound to recognize. The spring poet takes his 148 


\section{Interpretations}

life in his hand as well as his manuscript when he sallies forth to the publisher. Common sense commends this, if the law of the land does not; but editors should be held to certain responsibilities, such as seeking the truth and detecting error. Should be, but alas! they are forever giving aid and comfort to ignorance. Newspaper ornithology is all too apt to be irretrievably bad and a good deal of literary ornithology is open to criticism. Writers speak tro confidently of the characteristies of one month, ignoring the conditions of the month before it. Robins, blue-birds and song-sparrows, as familiar instances, figure quite incorrectly as so-called signs of spring. Theirs now are richer songs than in January; every note rounded and full, freighted to bursting with the joys that possess them, but the singers of this April day were neither absent nor mute in mid-winter. Declining to wade through snowdrifts or face the frosty wind to hear the midwinter minstrelsy, it is set down in books and announced in newspapers that the fields are then forsaken by the choristers of spring.

Certain stereotyped statements concerning birds appear in village weeklies and are taken 
up approvingly by metropolitan dailies. These statements deserve place now among cabinets of curiosities. Our grandparents read them believingly, and we are so far given to ancestorworship that we accept these dicta still because they are time-honored. I can imagine no other reason, for certainly they are not true. The blue-bird, particularly, has been persistently misrepresented. All winter long they kept faith alive in the coming of milder days. As an instance, the second after the memorable sleet storm of February 21, 1902, was a crystalline day. The world was in a glass case, cracked in some places and shivered in others, but still held together, like a vase that though broken yet retains the beauty of its outlines. The fierce crashing of ice-laden boughs, the pitiless sleet of a few hours previously had driven all animal life to such shelter as it could find. Much of such life, we know, is always fully prepared for such emergencies, but what of the birds? Can we say positively that, fore-feeling the storm, they fled? Certainly, if exposed to its fury, thousands must have perished. It is quite improbable that they rose above it and circled in quiet space until the fury of the tem- 


\section{Interpretations}

pest had been spent. In short, as in other features of bird-life, it is idle to conjecture; but this I do know, that thirty-six hours after the storm, every bird was in its place and the ecstatic songs of our several resident speciesblue-birds, robins, the cardinal and the songsparrow-announced the approach of spring. It seemed a trifle ironical, amid such arctic conditions, to sing of summer, but then the birds and ourselves see Nature from a different standpoint. To accentuate this superlatively wintry condition, a great flock of arctic snowbirds glittered in the sunlight as they passed over, alighted, not on the ground, but among the top-most twigs of a maple, twittered gleefully and were gone. How happened they to come? Was it against their will, caught by the gale and carried southward of their chosen field; or, riding merrily on the back of the storm, did curiosity overcome discretion? How easy to ask questions! 


\section{CHAPTER THREE}

\section{PERIPATETIC MEDITATIONS}

I can see no differences between twenty-two and sixty-two, but alas! I can feel them. As of old, I am all eagerness, these early summer days, to rush out of doors, as the sun rises, and I invariably walk out rather deliberately. I can hear the birds, as I did in years gone by, but I cannot follow them through brake and brier. If there is no bridge over the wide ditch, I must stay on this side of it.

Somewhere among the books, but as hard to locate as'a derelict at sea, is an essay on the art of growing old gracefully. I remember it by title only. Probably it teemed with excellent advice, but I cannot see how any one can grow old good-naturedly. Growing old is dying by inches, and how one can smile over loss of agility is beyond my comprehension. When I cannot leap over a narrow ditch, I do not exclaim, "What a pretty brook!" but mutter something 


\section{Peripatetic Meditations}

like "Confound you!" By so doing I feel that I defend my dignity.

But if I cannot run as I used to, I can walk, and, stumping away with a stout staff, get over enough ground to gather food for thought. Consolation here, and age needs lots of it.

What can be more delightful than to have an outburst of enthusiasm on your part met with freezing indifference by your audience? To see "who cares?" written so plainly on every countenance that each becomes a "speaking" one is, I say, delightful. Not at first, for the effect is quite the opposite, but a moment later when the reaction sets in and you learn, never to forget, that no one can have an audience equal to himself.

Poor Solitude! you have been much maligned. Here I am, quite alone, in the old woods and yet seldom in a city's streets have I been in more of a crowd. I am equal to listening to all I have to say and to all that Nature has to say to me. That surely is sufficient. More would prove "wasteful and ridiculous excess."

We forget too readily. This is the third day of the fifth month and the seventy-first since 


\section{The Rambles of an Idler}

that memorable sleet storm which dealt destruction with such an unsparing hand. In our enthusiasm over May-day blossom and the thrush's song at sunrise, we overlook the forlorm, leafless limbs of many a noble tree and note nothing of Nature's methods of restoration.

Little as we might have expected it, Nature is already beneficently busy. Branches that were hurled to the frozen ground are now partly buried in the turf and trailing vines are covering them. The ugly scars will be hidden and the world all green again. Close study of Nature's methods may lead us to better some of our own. She is a safer guide than those perverse people who have turned their backs upon her. But rejoice as we may, that the ruin caused by the storm is being made good, the cloud cannot be ignored because of its silver lining. The stately crown of oak and beech and elm is torn and tattered now. The battle raged fiercely, and little escaped its fury. The evidence of conflict is still everywhere. Were I young, I might count the years and mark the gradual restoration of these familiar trees. As it is, the trees I have known I shall never know 


\section{Peripatetic Meditations}

again. Wrecks and ruins that delight the poet and novelist have no proper place from my point of view. They blur the landscape; are blots on the fair face of Nature. They teach us much valuable truth, I am told, but I do not feel the need of it as yet. These are merry May days, not pitiless December ones, weighted with wise saws; and living myself, I am in love with life.

But when these woods are dark, what then?

Darkness has its disadvantages, it is true, but it is the same world whether bathed in light or wrapped in gloom. We really make the difference that we find and wrongly ascribe it to one of Nature's unamiable moods. Strike a match and not a tree will be found walking away nor the grass disappearing. Star-light is not sun-light, I admit, but the difference is in degree and not in kind. There is danger in darkness, but this is minimized by the exercise of care. It is no such hardship as people think to feel our way instead of forging straight ahead as we do during the day. If we felt our way, when we can see as well as feel, it would often be better for us. Light makes us overconfident at times and we grow impatient over 


\section{The Rambles of an Idler}

the very suggestion of caution. If the highmightiness of the average man were not shocked occasionally, sanity would become as rare as visible comets.

Certainly in some and possibly in all localities, there is one danger in darkness; that of meeting a man. It is an indisputable fact that man, the highest order of animal, is sometimes the lowest, and a blot upon Creation's face. Escaping, then, the machinations of some man gone wrong, these woods-all woods, indeedthough the night be dark as Erebus, are not without their charm.

The toad has been accounted a philosopher and it is much more that than a noodle. It is neither ugly nor venomous, as has been writ, and the precious jewel in its head is wit. When men have the patience to study the despised things on earth they lose a goodly portion of their self-conceit. If this poor batrachian had been better understood in other days it would not now have to bear the unjust burden of originating the despicable word "toady." The toad itself toadies to nothing. It is as independent as a black snake, and if not as swift, as 
graceful, as pitiless, it holds itself as no less an honorable denizen of the earth.

That toads are philosophical is evidenced by their selecting homes and remaining therein and not leading a vagabond existence. Diogenes in his tub was not more contented than are toads in their habitations, from which they hop, upon occasion, and being methodical when abroad, they demonstrate their claim to common sense.

I hear the toads now, though it is early in the day, as they are often heard at night, when they do not, I maintain, make night hideous. We, not the toads, are out of tune, so far as Nature is concerned, to think amiss when they are ringing the praises of the darkened world. The toad sees at night that to which we should not be blind. The last glimmer of light faded from the west and how much taller and more stately is every tree, now that it is dimly outlined on the blue-black sky. The twinkling stars seen through the branches are the trees' fiery fruits. Black trees, black leaves, and glowing fiery fruit. This is something worth a long walk at night.

Making no mention of the tiresome owls, 157 


\section{The Rambles of an Idler}

there are other birds awake to which it matters little what is the hour by the clock. Light or dark, they are equally wide awake and that weird Quok! we hear in the "wee sma' hours" is the cry of one such bird, the night heron. They are abundant here and so too is the little green, the great blue, and both the greater and less bittern. It is well nigh useless to peer into the sky when we hear the strange cries they utter. Unless they cross the face of the full moon, you will almost never see them. Such, at least, has been my experience. Quok! Quok! and the sound, the darkness, the momentary silence following the fading out of the landmarks, all these make for us a new world, but not one to be dreaded.

I cannot account for that disposition in man to invest what they call "strange" sounds with all manner of uncanny attributes. A heron is as harmless as a caged canary, and yet because its cry, Quok, is harsh, guttural, startling, a sound that commands attention immediately, those who hear it for the first time imagine endless absurdities, and if they never believed in ghosts before, lean to a belief in that direction now. Call the cry of the heron all the ugly 


\section{Peripatetic Meditations}

names you choose, it is really music. It aptly tells the story of the night. It belongs to darkness, to the shadowy side of Nature, just as the robin's whistle heralds the rising sun.

Why do they wander throughout all the night? Turning night into day for a given purpose is readily understood among ourselves. It is a necessity due to the demands of business, a strictly utilitarian condition. Is wandering 'twixt the clouds and tree-tops a matter of necessity or choice? The latter, from my point of view. Before midnight, every heron has sumptuously dined and the later wandering must needs be a grateful relaxation from long standing in the marshes. I have seen scores of herons of several species, crossing and re-crossing the meadow's and at times circling above them, as late as two A. M. There seemed no necessity for so doing, so we put it down as a matter of choice.

Perhaps when our air-ships are common as wagons, we too may wander over the earth and shout down to less favored mortals who are still toiling on the globe's surface, or trying to drown their sorrow in sleep. Though often abroad by day, these birds are well called night- 


\section{The Rambles of an Idler}

herons. So too are the others of their family. Whether green, blue, white or mottled brown, they are all given to nocturnal sport, noisy and demonstrative.

There is much preaching throughout the land, but the safest school for good manners, good morals and a common-sense view of the world we live in is out-of-doors. Compared with the conditions civilization has brought about, the out-door world never suffers. Candor, a word merely with men, is the keynote of every wild creature, however humble, that we meet, and this is refreshing, enough so, it seems to me, to take us oftener into the woods.

The tirade against dirt so constantly heard is probably the most tiresome item of the stock in trade of housekeepers' communications. Poor dirt! Pulverized rock, tried by frost, purified by fire, washed by the rain and dried by the innocent sunshine, and yet more roundly abused than anything else in Nature. Thank Goodness, I love the dirt! Love to walk on it, to play in it; yes, to burrow waist-deep in it and, emerging into the light of day, feel that I 160 
am not an unfit object for the blessed sun to see. Better still, I am duly thankful that I am comparatively free from the restraints of those habitations where a speck of dirt is held in as great horror as a crime. Some superlatively particular people, did they know it, are superlatively stupid. Wisdom does not brighten their eyes, as lightning plays upon the mountain's brow. Well, I had rather have the marks of my collie's muddy paws upon me than the reddening of squeezed fingers following the grip of senseless formality. Dust that smarts the eyes, tickles the nostrils and soils the pages of our treasured books is an abomination, but such "dirt" is far removed from the honest earth into which I love to delve and which the while tells a.truthful and most fascinating tale.

It threatens to rain. Just what threatens is not a matter of importance. "It" is a convenient intangibility upon which we can hang all sorts of theoretical conditions. What is of importance is the fact that the sky is overcast, and the sunlight so dimmed there are no shadows. Never was better evidence adduced that May days can be delightful, yet without direct 


\section{The Rambles of an Idler}

sunlight. It is a dark day but not a dismal one.

There is much in Nature that defies language. A correct description is alike beyond the mathematician and the poet. An approach to it is all one can accomplish. The writer can but outline; the reader must fill in for himself. As an instance, the air we breathe, when it threatens to rain, is not just the same as in ordinary weather. It is equally acceptable to the lungs but we appreciate a difference while inhaling it. We can speak of electricity, ozone, oxygen, but we must breathe that subtle something then abroad to know what it all means. At such a time, too, there is not so bright a light as when the sun shines, yet the horizon is more distinct and intervening objects stand out as not before. An apparent contradiction, so far as mere words go, but it is true, nevertheless. No bird sings more loudly than when the sun shines, yet we can hear each note, just before the rain, more distinctly than in fair weather. Words, mere words, again! The ring of every bird's note, the odor of every blossom, the effect on the eye of the peculiar light; in brief, the comprehensive impression of all surrounding us laughs at language. 


\section{Peripatetic Meditations}

Nature deals directly with us and some of her gifts are beyond human power to transmit. No page can be printed which can do more than urge the reader to seek for himself. Take the world only on hearsay and you are a stranger in it for the term of your natural life.

I do not know when the mill-pond was established. It was certainly as long ago as the closing decade of the eighteenth century. It is sufficient for my purpose that it has been a pond since I first passed this way, and that was long before I was allowed to come alone. Every man has his individual "long ago" when the world meant so much that failed us as the years rolled by. A country mill-pond, a boy fishing, sunshine, song-birds, perhaps a boat-a picture, this, of an Elysian field that age can see -only when blinded to the facts. But this is a May day. Fit for meditation and not for melancholy. The latter, if it shows itself at such a time, is a mis-fit. May melancholy! As well speak of a righteous sinner!

Here I am, but not as I have often been before, walking on the dry bed of the old millpond. The past is not always so hopelessly 


\section{The Rambles of an Idler}

irrecoverable as we think. The valley that now is is the valley that once was, the one Nature fashioned with sloping bank, level meadow, a bit of resisting clay capped with button-bushes, and a spring brook, so reckless it did not look where it was going and faced all the points of the compass before settling upon some one of them. Happy brook, surely, for in all these years it was hidden it lost not the secret of its youth and sparkles to-day as if no shadow had ever fallen upon it. A happy brook with white pebbles strewn throughout its way and the silvery minnow and checkered darter flashing in the ripple as they did when my forbears, as little boys and girls, played hereabout.

Only the garrets of our oldest houses retain a colonial atmosphere nowadays, but I found it here this morning, out of doors, in a winding, narrow valley, that has been drowned a century and more, but with the breath of life again in its lungs, and trembling with the same exuberance of joy as it did before man marred what Nature made. Fresh green leaves, the incompar-able yellow-green of early May; warblers by scores that dropped in upon the scene before the sun rose, the exultant rose-breast and the 
reminiscent thrush, rollicking cat-bird and ghostly chat. Then too, the bluet and violet, star of Bethlehem and dandelion, purple lungwort and pink azalea; color, color everywhere! Music, color and Time turned back to the youthful years of the lonely rambler. A man turned boy and in a colonial setting. Not my poor self, merely, in the dry bed of a departed mill-pond.

No aquatic plants have raised their expectant heads above the sun-baked mud and turned back to Mother Earth, wondering what had happened. At least, I could find no evidence of this, but in their stead, germinated seeds carried hither by the March winds and April gales. These are not vigorous growths, but relieve the monotony of barren, brown ground, and in time would flourish. Nature soon obliterates all traces of man's interference when she has a free hand, but the new dam and re-erected mill will be finished ere long and then the water lily and spatter-dock, pickerel weed and milfoil will reign supreme.

It is the meadow now, however, not only of early Colonial days but of the Indian, and I have been wondering if any traces of their handiwork still remain. My search therefor was fruit- 


\section{The Rambles of an Idler}

less. It requires but a thin film of mud to conceal archaeological prizes effectually, so my failure was but negative evidence; all of which should be remembered and unfortunate conclusions would be avoided. What I did find was a pewter button. It might have belonged to the coat of the first miller. It is not always safe to say, even to one's self, "it might have been." Innocent words in themselves, but how they can play hob with the facts! They can distort our mental visions until the world turns upside down and we never suspect how we are fooled. When you find pewter buttons label them as such and until you find the coat from which they came, do not venture to comment. Excellent advice; but how prosy becomes the day's walk when you cannot indulge your imagination. Do not buttons prove that there were coats, just as the foot-print before me proves a man has recently passed by? All my life a snapper up of unconsidered trifles, I venture to speak with a trifle of confidence. There is, however, one really safe line of thought when discarded odds and ends are gathered up. Buttons, for instance, are like Indian flint arrow-points, almost meaningless of themselves. We can think of a coat when we 166 


\section{Peripatetic Meditations}

find a button and so too of an arrow when we find its head, and just as the arrow indicates a bow and this in turn a man to use it, so the button leads to the coat and a man to wear it. So far safely; but this pleasant May sunshine makes me venturesome and I go a step farther and say to myself, perhaps this button belonged to the coat of the man who built the mill. When we say "perhaps," we are always safe. The word is a breastwork through which no critic can shoot. At all events, there was a miller, once upon a time-blessed words these, once upon a time-and tradition has it, he was a man of many parts;-miller, sawyer, cabinet-maker and cordwainer. His grandson, whom I remember, was a sawyer only and all his talk was of timber. He bore much resemblance to a gnarly oak and his words crackled like dead leaves in winter. If his faults were many, he had a few virtues and these, like oaks among brambles, overshadowed the undergrowth of his make-up. He was proud of his grandfather and in justification of his own inferiority, asserted that the world had "tamed down" since the old man's day, and so had he.

Soon, as I said, there is to be a new mill-pond, 167 


\section{The Rambles of an Idler}

a new dam, a new mill, and all I can hope for is that the falling water will sing the old song that helped to while away many a summer afternoon. The same song, that nothing can improve, over and over, high and low, gentle and fierce, soothing in summer, pitilessly harsh in winter and, though for more than a century it has kept silence at arm's length, never wearisome. A tonic sound, like the wholesouled whistle of a cardinal grosbeak, which restores what is lost, which rebuilds what has fallen.

The shadows lengthen as I wander on. The light fades from beneath the cedars, and the thrush, moved by the stillness of the sunset hour, sings his marvellous song. One by one the glittering stars appear. Another of these blessed May days, passed into history.

If we could see ourselves as seen by others, would we do so? Is not opinion of self perched upon so high a pinnacle that it overlooks all else in the universe? Men will cease to talk about themselves only when the Heavens fall. They do not deal in facts so much as their personal relation thereto, and it is the former only that concerns the average listener. There are ex168 
ceptions, and these prove the rule perhaps, but more effectively demonstrate that all could free themselves of the pernicious tendency, if they would. I listened once to a thrilling narration of the upsetting of a boat and what followed, and did not suspect that the narrator was the hero of the story. I learned that later, by accident.

It may be merciful that those who are lacking do not suspect their limitations. He is really a wise man, who, being a fool, knows it, and a brave man, if he freely admits it; otherwise, he is a fool indeed.

"If this were sound reasoning, all would turn to suicide and the race disappear" -is the comment of one who is not afar off.

Again, perhaps; but if people would stick to facts and not their relation thereto, I still maintain, the world would be happier.

Nature loves the number, three. She trinitates in more ways than one. Morning, noon and night. It rains for three days. It is hot, hotter, hottest in summer and cold, colder, coldest in winter. The seasons each are three months long and with the wild strawberry, it is 169 


\section{The Rambles of an Idler}

three weeks 'twixt blossom and fruit. Wild strawberries! A poem in two words that no exploitation of stanzas could improve. A little prose, however, may do no harm.

I know a bank whereon this berry grows and with it purple crane's bill, wind-flowers, buttercups and bluets. To-day, too, the white sepals of the dog-wood still show and not all of the pink azalea has faded. Jack-in-the-pulpit holds forth to the oven-bird scratching among dead leaves and red-starts flash among the old oaks' branches above me. I rested for a time on a cushion of rich green moss and plucked red berries; plucked and ate, while I heard the straining snorts of freight engines, the rumble of traffic on the high-way, the steady hum of the town borne hither by the breeze. The world is very busy and let us hope, happy; happy as I was there, alone with the trees, flowers, birds and fruit; as happy with those few berries as the man of business clutching the profits of harddriven bargains. The strawberry does not ripen that I may eat, but Nature was in a generous mood to-day, and had enough for her purposes and mine. I could eat and be merry, with a clear conscience. 


\section{Peripatetic Meditations}

Even when May has to face clouds, fog, drizzle or beating rain, her gladness shows through her tears and the rambler laughs at her plight more than he sympathizes with her woe. If all that follow in her train are not disturbed, why should we be cast down? The chilly east wind might have been more considerate and staid on the ocean, I felt, at first; but the birds seemed not to mind it and sang as usual. Swallows, that yesterday filled with life the empty space above, now gathered on the wires of the electric railway; but they twittered contentedly accepting the chill day with becoming cheerfulness. One good thing happened. The north-bound warblers were induced to stop over for a time, and when I saw to-day the fire-fronted Blackburnian, the matter of foul weather was absolutely forgotten. .

Their song was an earnest invitation to remain afield. See, see, see, see! I did see a great deal for a dreary day. Saw that wild life took things philosophically. The rain was needed and perhaps they knew it. Psychology: says otherwise and limits animal intelligence to mere rudiments. Perhaps. I should like to have birds' eyes in my head for half a day and 


\section{The Rambles of an Idler}

see the world as they do. There were warblers everywhere and if the slaughter of insects bore proportion to their activity, the ranks of flies and larvæ were surely much depleted. As so often happens, their united voices reached to the dignity of song. Few species will remain. In June, the redstart, summer warbler, Maryland yellow-throat and black and white creeper will be all that one is likely to see in a day's ramble, but they are sufficient to brighten any outlook. The oven-bird, too, will be here, but it seems more like a little thrush. One word about its song. It was said some years ago that the notes of this bird were best represented by the word "teacher," uttered five times with a steadily rising inflection. This assertion implies that the accent is on the first syllable, and that the sound of $\mathrm{E}$ is prominent, followed by the roll of an R. Possibly so in the northern woods, but I have been listening to one of these birds for several days, as I have listened to others for forty years past, watching it closely and taking my observations early and late, in clear weather and when the air was laden with moisture, and can say confidently that the word "teacher" bears no resemblance whatever to the oven- 


\section{Peripatetic Meditations}

bird's song. The notes of the Jersey bird are distinctly sibilant, the accent very marked and invariably on the second syllable, and the two words "it is," four times expressed, each time with added emphasis, are accurately descriptive. The bird might well be called the Insistent Accentor.

As we watch this common bird of the woods, seeing it under all circumstances, the impression arises that it is a creature of strong convictions and an earnest upholder of squatter sovereignty rights. It is self-reliant and moves with the dignity of a lord of the manor. Its "song" is not akin to the warble of a blue-bird or the clarion call of an oriole, but suggests to man, at least, a distinctly positive expression of some conclusion reached; an insistence that something is.

All- other birds silent for the moment, the dead leaves no longer crackling under our feet, we pause for an instant, thinking we have seen a movement of an object on a dead limb near by. We wait and watch. Presently, a little bunch of brown feathers trips along the branch, takes on more definite shape, stops a moment as if suspicious of us, regains its confidence, recalls 
its thought of a moment ago and then the still woods ring with an emphatic "It is, $I t$ is, IT Is, IT IS!"

Fiddle-heads are fuzzy, bright brown and shapely as a bishop's crosier;- - some without the crook and green. In every stage of advancement toward completion and the reason is evident. A matter wholly of the temperature of earth and air; for I find many a nook where it stays cold as charity all through the month, and yet the fern is plucky enough to hold on and in June will make the spot luxuriant as a tropical jungle. Where ferns flourish, the world is pretty enough for the most exacting creature,fit for humming birds and the summer warbler; yet to-day a stolid rough-backed terrapin crept over the mud and seemingly paid no heed to the beautiful foliage waving gracefully over him. It was, from a human standpoint, an example of the sublime and the ridiculous. Turtles are well enough in their way, but sometimes they may be in the way. This rough-back crawled to a higher point and surveyed the world from a hillock of dry sand. It surely never saw a fairer landscape, but chelonian utility was perhaps its 
only thought. It evidently failed to find things as it wished, so turned about and hid itself in the soft mud. I have known people to play turthe in this fashion. Although a May day, the air is too cool, the sky too cloudy, the breeze too fresh, and so after a sniff from their doorway, they turn about and wallow in the dust and stuffiness of their houses. As if May days were every days and life without end.

Whichever way I turn I find an Indian has preceded me. Try as I may, I can leave no enduring trace, and yet little the Indian did that there is not a record of remaining. It is easy to fill my pockets with relics of these almost forgotten people, but not so readily can I picture them as they were. The world then was Nature's world and they were Nature's people. They wrought their commonest utensils in stone; we, in wood. They lived a purposeful life- to do otherwise was to court death; we too often lead a meaningless one. Else, why have coined the word "artificial?" Here are three arrow-points, one each of jaspar, quartz and slate, but the shafts have perished with the bow, and the archer's bones are dust. How many of 


\section{The Rambles of an Idler}

us leave so much as an arrow-point behind? I have nothing about me as imperishable as these dexterously chipped stones. What a joy it would be to put on record an imperishable thought!

As I stoop to pick from the newly ploughed soil another arrowpoint, fancy gains the mastery and the field disappears. The forest is restored; deer lurk in its shadows and the hunter's moccasined feet silently press the dead leaves where I would have noisily trod. Now, if I chance upon a mouse or see a squirrel on yonder fence, I am fortunate. The thoughts that such a change has wrought, are vexing. A cloud appears in the blue sky.

We are too apt to be discontented and grow morose even, if we dwell too much upon the irrevocable past. Had it been the climax of the world's purpose, it would have remained so. Evolution stopped with the appearance of man, but the Indian is only a phase of human progress. The aim of the universe is towards still better things and we are better employed with the present than forever brooding over the past. Some people speak of the "good" old times as if the present were irretrievably bad. Well 


\section{Peripatetic Meditations}

enough to give a passing thought to the Indian that was, but not such fixed attention that the present is lost sight of. Now, with what is, is none too trifling for our strength. Let us solve the problem set before us as did the Indian that which confronted him in past ages. The harvest that I yearly gather from this one-time home of another race is better for me than the venison and berries that were cooked over the coals which still blacken the ground where I stand. It is enough to know that the Indian once possessed the land and that now I have taken his place. Nature expects other results from me. What is expected? That I would know. When the Indian I meet in the realm of shades, it will be time enough to compare notes.

It is a pleasing thought that water can run rapidly, yet without noise; swift, sure and silent. Not so with ourselves. There is a great bustle attending our least efforts. We are apt to command attention more by the noise we make than the good we effect.

Across the ploughed field is a long line of button-bushes and these border a lively little creek. Where I reached it, the stream has 


\section{The Rambles of an Idler}

broadened to a shallow pond, its bed checkered with squares of white sand and green, waving milfoil, and a narrow channel divides the space, which looks like a black hand. It hides effectually all it contains. The contrast between the bare sandy spots and those covered with vegetation is very marked. In the former are several beautiful banded sunfish that are as conspicuous, with their ebony and silver markings, as many of the tropical fish. With fins somewhat depressed, they move leisurely about but, spying prey, at once they hold themselves erect and dart at objects which I cannot detect. I can judge of what they are doing only by their actions and this is usually a safe thing to do. People do not run unless in a hurry, nor are they given to flinging their fists into the face of the wind; so these sunfish dart about when there is something to overtake and float lazily when there is nothing else to do. We can see ourselves in any school of fish. It is for some purposes an excellent school to go to before the day of our enslavement to self-conceit arrives.

With these black and silvery-sided ones are others, somewhat larger, rich brown in color and thickly spotted with richest, royal purple. 
They too make a fine show when they turn a little to one side or the other, but if directly beneath us, they are, like all fishes, but dark streaks in the water. Evidently their color was not meant to please the idle rambler that happens this way. In all probability the world was far more beautiful before man saw it, than it has been since. Man came upon the scene after everything was old and much was ruined. He is now a good deal like the creator of a museum of archaeology, a caretaker of the antiques time has spared to us. If these pretty fish are not pleased, looking at each other, why such a display of color? These are long days but not long enough for those who begin asking questions. The sunlight reaching to the white sand is attractive to the fish; and they gather about it, but they are never incautious. The shadow of my broad-rimmed hat, as I moved, fell upon them and when I looked again, not a fish was to be seen. Probably they had the thought of a heron or a king-fisher and took no chances. They indulged no curiosity to-day, surely, but fled from the vaguest hint of danger.

Not all summer's leafy bowers are on dry land. Submerged plant-life luxuriates here, 


\section{The Rambles of an Idler}

graceful beyond description. Only our ferns are comparable to it. Fishes have their forests but to explore them is unduly adventurous. I never was equal to diving. Not only adventurous but dangerous. Savage creatures lurk in the darkest recesses of these rank aquatic growths. The snapping turtle, for example.

In place of attempting a personal exploration, I sent a stout stick as my representative-a crooked one, perhaps, more appropriate-into the milfoil, bladder-wort and yellow pond-lily, the leaves of which last named plant are very beautiful when submerged and quickly turn to green slime when removed from the water. The steady current soon set the disturbed plants aright, but the hidden fishes were more seriously disturbed. Out skurried many of them and besides the sun-fish, there came a full-grown, grim, black pirate perch. Evidently disliking the light of day, it moved about petulantly and soon found shelter under a root that projected from the sand. There, when quiet was restored, it held itself in one position by the slightest possible fin movement. Such of these fishes as I have kept in an aquarium were distinctly nocturnal in habit, during the day remaining in the 


\section{Peripatetic Meditations}

darkest corners or under a stone arch in the tank. When, occasionally, I completely shut out the light, they became active immediately and searched for food. Suddenly letting in the light again, they quickly returned to their posts.

This simple experiment, always with the same result, led me to conclude that pirate perches are nocturnal. That was long ago and for years I have not seen one of these fishes. That which I routed from the weeds to-day, told the same story. They are carnivorous and gluttons, even for fishes. I have often known them to swallow a minnow, head and shoulders, and patiently await the process of digestion before clearing their jaws of the projecting body of their victim. I saw a pirate perch, in an aquarium, take secure hold of an angle-worm, and while two or more inches of the body were lashing wildly about the "pirate's" head, the fish chased a small minnow until it cornered it. Of course it escaped, but not quite unscathed. The "pirate's" one idea is a full stomach, that is, if fish have ideas, as we ordinarily use the word. It is an open question. Certainly some fishes seem to have other means of enjoyment. Many of them play, if ever a kitten does. 


\section{The Rambles of an Idler}

The house-wrens are now here and nest-building is over. There are no sticks to be carried and no more quarreling over their availability. Life has become one endless round of song, varied by lively chatter and spiced with an occasional dash of acrimonious debate. When the pair came-I presume they are the same birdsto the cozy corner in my north-side porch, they found the English sparrows in possession. That was April 23d. Of course there was a fight. Nothing like argument, but at once a deal of vituperation, and, on the wrens' part, determination that became desperation. Possession is nine points of the law, and this was the sparrows'. I was forced to come to the wrens' aid. This I did by closing the entrance to the nestingplace and making a new and smaller one. The sparrows were now at a disadvantage, and held out for three days only, standing guard, and preventing the wrens going where they could not go. Then they gave up. What appeared a purposeless labor on the part of the wrens was that they removed twig by twig all that the sparrows had gathered to complete a nest, and then, having cleaned house, which proved no very easy matter to them, they took back about as 182 


\section{Peripatetic Meditations}

much material and some of it, I know, was that which they had removed.

As I have sometimes seen, I did not, in this case, note the wrens and sparrows actually come to blows. It was a war of words and no one could have heard it and not have been convinced that birds' vocal powers have a wider range than the utterance of musical sounds. If it is posisible to interpret what we hear and see in other creatures than ourselves, then there was talking as well as expletive, to and fro, 'twixt wren and sparrow.

A stormy day, at last, an indoor day, and I have opened a book for the first time in a month. I soon tired of it. My recollections of recent out-door rambles were too vivid and the contrast 'twixt book and memory too great and to the former's disadvantage. Why not be entertained with indoor thoughts of our own thinking?

In modern houses we are too far from the storm. We may not wish to feel it, but I protest against shutting out all sight and sound of it. The shelter of an open shed is my ideal of a refuge. I love to hear the rain upon the roof. 


\section{The Rambles of an Idler}

Though every drop was big and round, and there were millions of them, a satisfied wood peewee perched on a poorly protected twig and caught many a draggled insect that ventured abroad. What a fitting song was that of the bird, blending so admirably with the sighing of the wind and the creaking of the elm-tree branches. Pee-ah-wee! Pee-ah! Perhaps the bird found pleasure in his melancholy; I have known people to do so. I found mine in anticipating the general refreshing of Nature, remembering what a rain means after weeks of dry weather. Much will happen in a single night, after the storm passes. Many a plant will wait for moisture, if it waits all summer. I shall look for green growths confidently where now it is but bare sand. Every drop of this blesséd rain is a fairy's wand and has illimitable transmuting power. If one's thought of rain is only to keep out of it, much is lost. It is not one of Nature's holidays and the world idle, and the rambler is unwise who makes a holiday of it and hides behind a door. Rainy day rambles are among our choicest experiences, but it takes a man of some courage to face a driving northeaster. 
Men of common sense have a hard time of it in this world, the earth is so full of people lacking it; but this is not the only vexatious condition that is met. Before the perversity of inanimate objects that of the semi-idiot pales to utter insignificance. I am not to be convinced by the mere telling that a hammer does not discriminate between my fingers and a nail and hits the former maliciously and lets the nail's head go unscathed. Madam's pin cushion is peculiar and pins and needless make it a point to point outwardly and finger ends are notoriously blind. Buttons and button holes, collars and collar buttons, I know, and hooks and eyes, I am told, are perpetually at odds, and when their differences are set at naught by man or woman, they vent their spite by parting company when their close association is most desired. Who has not known the recalcitrant stud which rolls to that precise point where it knows the human heel will be most impatiently planted? Never the living creature breathed that could not be provoking upon occasion, but how trivial, after all, is its perversity when compared with such familiar objects as chairs where you least expect them and half-opened 


\section{The Rambles of an Idler}

doors in darkened rooms and ill-placed bric-a brac!

"I didn't know it was there!" exclaimed a friend, recently, as he sent a bit of glassware to the floor; "why didn't it get out of my way?" Sure enough, why didn't it? If crystals be alive, as it is said, why not cut-glass and eggshell china and all the fragile tribe of art production? It is an old way of thinking which should be discarded,- that the fault when accident occurs is all our own. There is nothing we prize that is really not our enemy and forever on the alert to take advantage of us. With what a joyful splash goes the extra drop of ink to mar the paper when timidity attempts a love letter. It is enough to make one suspicious. That drop of ink was as malicious as it was black. Neither youth nor pen had any control over it. It leapt into mischief in spite of them. There may be much that is illogical, but nothing truly remarkable in idolatry. The mind in Nature's children, not weighted down with learning, sees with keener vision than is true of ourselves and the foxy animation of inanimateness is very evident to them. 


\section{Peripatetic Meditations}

What, now, of out-of-doors? Is there nothing but serenity under the bright blue sky? Let us see. I hold no tree is so happy as that with the stump of a dead branch projecting where it is surest to be in the way. He who loves to climb well knows how often it happens that descending from a tree-top, we give an eager jump at last, glad to reach the ground. We leap into space-and halt there. With what solid satisfaction that stump, all innocence in appearance, stops us in mid-air, and we dangle until some important portion of an important garment yields and we find ourselves sprawling on the ground, released, it is true, but oh, so ragged!

It is not conducive to good humor, when angling and reasonable anticipation is at its height, to be teased by hope-inspiring nibbles, and then apparently rewarded by a vigorous tug at the line, to haul in exultantly, hand over hand, and as the fish appears, a splendid catch-to have the line break. How very suddenly the green world turns blue.

Whether cotton, hemp or silk, that line was once alive; product of plant or worm, it matters 187 


\section{The Rambles of an Idler}

not. Accidents are too common to be explained as accidents. It is more rational to conclude that the world is so full of life that it permeates every stick and stone and even every product of man's handiwork. Outwardly dead as the proverbial door-nail, but perversity remains. It is surely not to be questioned that never a tack escaped from its paper case or proper place in the carpet but for very joy stood on its head and fiendishly anticipated the world's contact with its other end.

Time would not suffice to write the history of a world, the perversity of which is its sole omnipresent feature, but its victims find some relief in occasional expostulation. It would be hard indeed if there was not salve for every wound. This is not so much an attempt at an essay as a victim's cry, which he would have prove a warning, were it not that this is but a word in the dictionary. Our own perversity enters a pro. test here. No man holds he has need of knowledge got so easily.

A century ago, a slippery, slime-coated, serpent-simulating snag in Crosswicks Creek held my grandfather's boat for four long hours. 188 


\section{Peripatetic Meditations}

Only the tide could help, it seemed, and it took its own time about it. Now, time and tide wait for no man, but we have sometimes to wait for them. They know how helpless we are, in spite of all our boasting, and with them perversity makes its headquarters. Time and tide: I too have had to do with them and grown old in vain contention. That same snag of 1804 still flourishes, and not long ago, at low tide, hid itself so cunningly that I was entrapped, but I did not play the part of waiting as grandfather did. I attempted to wade ashore; and if snags are perverse, what of mud? The Crosswicks mud is all suctorial discs. I could scarcely move. To take a step was impossible. My grandfather was wise in his day. The snag held the boat, but the boat held him. I let the snag have my boat and the mud had me.

"If you had had but patience," I was told, on reaching home, "there would have been less trouble."

This is as near to a solution of the vexatious problem as we are likely ever to come. Have patience. With it, perversity may be shorn of some of its virulence. The end of life's journey may be reached with both body and soul intact 


\section{The Rambles of an Idler}

in spite of the persistent malevolence of the inanimate world.

There is no hour like that of sunrise after a three days' storm. The pent-up energies are all set free. Nature rejoices now with a vim that bewilders. Nothing is still. The morning breeze reaches the lowest blade of grass. The human brain needs all its joints well oiled at such a time. Thinking can be too slow a process when Nature hustles. A hundred birds about you and all shouting at once demand more than the brain can accomplish. To-day, only the clouds were leisurely paced. They would not be hurried, though the heavens fell. The eagle that darted among them moved them not.

It is exhilarating at first, but wearying soon, not to know which way to turn. To-day, at sunrise, was the ornithological high tide of the year. An opportunity to consider birds in general; to consider any one in particular was impossible. Each endeavored to out-sing his neighbor. Not one chirped, all shouted. There was no obstructing dust or moisture in the air, nor envious wind to carry off the sound. It was on my part a breathing of music, and with it that 


\section{Peripatetic Meditations}

subtle scent of leaf and flower when all is quickened with the thrill of life and death a thing forgotten.

Earth's renaissance, and why not ours? Let us feel young again, if we cannot be so. There are yet days to come in this blesséd month, and while they last I purpose laughing at my aches and pains. 


\section{CHAPTER FOUR}

\section{CANDOR}

Recently a lady remarked to me, "Let me tell you candidly that I never thought of such a thing." I was forced to admit that I-was mistaken and both of us were lying. There was no other way of settling a rather trivial matter, as society is now constituted, and we each privately congratulated ourselves at being freed from an embarrassing circumstance. The adopted method of the world was followed to a nicety and now, thinking it over, I wonder why the word "candor" is not dropped from our language. Why, indeed, tax our memory with a word that, while having a meaning, is never put to any practical use?

We daily hear, when strangers are introduced, "I am very happy to have met you," when such a desirable phase of mind is impossible. A stranger is an unknown quantity in our lives. We can give him or her no rational 
consideration until subsequent and often frequent interviews demonstrate the desirability of acquaintance, and yet, without hesitation, we assure the new comer into our lives that the chance meeting has caused us happiness. If so, happiness must be a very cheáp commodity. We pretend to be confident, on the instant, that an added blessing is ours, and it is mere pretense. We may mean that we hope the meeting will prove productive of mutual satisfaction in the future, and yet we do not dare to say so. What, pray, of that quality known as candor?

It is suggested that to go into details when a matter is of no particular importance would be a waste of time, and this, of itself, excuses every little slip and petty frivolity of speech in polite society.

A waste of time? I take it that time with candor eliminated is not worth the value usually put upon it.

"A matter of opinion," suggests a critic.

"And what is not?" I ask. "As one that rebels, I do not mean to be silenced by those that subscribe to slavery. Though I turn every friend to a foe I will say what I think."

"Then you're a fool," remarks the critic. 


\section{The Rambles of an Idler}

"So be it."

But really, there is no good reason why we should not try walking in difficult paths. The exercise is good for us, even if the attempt to reach a goal is a failure. Pope suggests, "be candid when you can," thus intimating there are times and circumstances when and where we cannot be. Recognizing such, why not avoid them?

"This is lack of candor," asserts the critic. "Who, then, is not a liar?"

Here, too, is another phase of the matter, and a false view, I take it.

Give me the arow'd, the erect, the manly foe, Bold I can meet - perhaps may turn his blow; But of all plagues, Good Heaven, thy wrath can send, I pray Thee, save me from the Candid Friend.

But a moment ago my candid friend called me a fool, but he is none the less my friend because of that. It may be after all that he is right, and, whether right or wrong, cannot affect the final issue. His candor is his attraction. If he was otherwise, he would be insipid; as salt that has lost its savor. His candor spurs me on to attempt the discovery of the truth, whether a 
fool or not. This adds a zest to life, so great a one that I hope to die in ignorance.

Truth must be sacrificed for politeness' sake. As the world goes, this cannot be questioned, but why language should be distorted and words used in a way not warranted by the dictionary, is not plain. It is strange that our real selves cannot be shown to others without offense. Candor-the dazzling whiteness of absolute honesty - which should be a desirable quality, is forever kept in the background. To let it come to the forefront is not to gain friends but to make enemies. To insure success we must be polite, diplomatic, vague, insincere; to be popular we must call black white, and in sober truth lie continually that no hitch occur in the smooth running of the world. We must play a part, evade the actualities and give to others a pleasing impression, though a radically false one. Little wonder, then, that long ago the words of our mouths and the thoughts of our hearts should have been looked upon as having naught to do with each other, and the conclusion reached by some hard-headed, brutal Dutchman that while speech might be silver, silence was 


\section{The Rambles of an Idler}

golden, or speech being human, silence was certainly divine. Candor is social suicide. Thus is constituted society, in the common acceptation of that term.

Beyond its pale, there is found a saving remnant of this admirable trait, from which excellent lessons may be learned. To meet with simple folk who mean what they say is like passing from a stuffy parlor to the pure out-door air. It may shock, like intense cold, but not perniciously; rather an exhilaration that results in no baleful reaction. Wholesome truth, like wholesome food, builds us up as surely as unwholesome insincerity tears us down. Build up bricks with mud instead of mortar and the structure falls. Still farther away from society's sacred bounds, the wild life in the woods says what it means, as when the snapping turtle goeth about with murder in its heart and murder in its eye as well. Only a fool will be deceived by it, and is this not to the turtle's honor? The rattlesnake gives fair warning before it strikes. It is an honest snake, not a sneak, and we cannot say as much of all people whom we meet. It is scarcely asking too much to treat the inferior world with fairness. 
In my daily rambles I find abundant evidence of this delightful condition, to use a popular example of accepted method of distorting language. If others do not, it is because they measure the out-door world by drawing-room standards, and so frequently is this done that many a misinterpretation of what a bird or beast does or means has very often been given us. The hissing of snakes, harsh chirping of birds, and snarls of the wild wood's furry folk are candid expressions of these various creatures' opinions and not necessarily uncomplimentary because vigorously uttered. Wild life knows nothing of white lies. It simply says what it feels, and is willing to accept all consequences. If you enter its domain in a friendly way and not on mischief bent, you will not be berated, but asked only that the golden rule be obeyed. Not long ago, in the white light of a full moon, I came suddenly face to face with a jovial, roving owl. It stared at me for a moment, clicked its bill, chattered a few syllables, crisp as the breaking of thin ice, and left its perch abruptly. The true interpretation was: "I doubt your motive in being here." It acted accordingly. Here was candor. But if I am suddenly confronted by a 


\section{The Rambles of an Idler}

human being and at the time not wishing to be disturbed, and, saying so in plain words, turn away, then it is rudeness, and pitilessly condemned. It is very inconvenient, to say the least, and I prefer the owl's standard. My only treasure is my time, but the world sees fit to lay claim to it, it appears, and I must not demur. At least, I will have so much candor as to express my opinion.

Such a view of the world into which we find ourselves thrust without being consulted is not of necessity inimicable to friendship. As all work and no play is destructive to man's best interests, so isolation from humanity or absolute distrust of it would be fatal to any really valuable outcome of a life. We need friends as surely as we need food, but a true friend should not be disturbed by candor. There should be such understanding between congenial persons that an honest expression of opinion will not prove a shock to him who hears it. If there is not this, then the friendship is certain to be one of form, not fact, and, like many an apple in my orchard, as I learn to my sorrow, hollow, if not rotten, at the core. 


\section{Candor}

I am told that those are most successful socially who are most cunning at deception; that they only have troops of friends and always keep them. They are welcome to the possession. It is too great a tax upon time and temper to be forever struggling to conceal the truth. I prefer the owl that I met the other night to the man who owns the woodland tract wherein I met it. Candor is far older than humanity, and the race has not gained by persistently ignoring its existence. If we are permitted to be candid with ourselves, it should not be amiss to be equally so with others.

Akin to the lack of candor is that misuse of language which carries us away by ringing in our ears high-sounding phrases, and, because the ear is seduced, allowing our sober secondthought to be equally wronged. This effect of words upon our sense of hearing is one worthy of close attention. Music is not confined to the melody that wells up from tuneful throats or responds to the skill of those who have gained mastery over sound-producing instruments. Words may be so spoken, if arranged in cunning order, that the ear is charmed. We are made captive by rhythm and accent-by accurately- 


\section{The Rambles of an Idler}

measured lines and rhyme: taken, indeed, so completely captive that judgment suspends its function, and we are led on, as it were, blindfolded. We are carried away; we dance to whatever measure cunning whistles, and are so happy as puppets in another's care that we shudder at the thought, if it arises, at a return to personal responsibility. The often-quoted

Lives of great men all remind us, We may make our lives sublime

is an excellent example of what is meant; for let a beam of light fall clear and direct upon these lines, developing and defining all that is in them, and their true value will be accurately discerned.

Lives of great men do not remind us of anything beyond the fact that these men were great. No eager student and devoted follower of any great figure in history ever became, so to speak, a reincarnation of that man. All greatness is necessarily unique in its day, and must necessarily remain so. We can make our own lives sublime just so far as there is innate sublimity, providing we have the courage to bring it outall of which has naught to do with familiarity 200 
with another's story, but comes through influences over which we have no control. Greatness is as much a fruit of its time, irrespective of the past, as apples, good, bad, or indifferent, are the product of an orchard.

Study of the difficulties that beset the path of greatness, when they did beset it, and how they were overcome, may serve to teach us how we may get over obstacles that block our progress, or seem to do so; but this does not necessarily lead to sublimity of life. To pull through at all is the measure of success that is the lot of most of us; and ambition, unchecked, is as dangerous as fire, which may warm us to a more healthful activity, but in which the power and disposition to consume are always present, and the world hears only of the scanty few who escape - the little handful upon whom Fortune smiled. General literature does not require, and poetry should not depend upon, license. Figurative expression is too liable to be misconstrued to warrant its use, except in the rarest cases, when befogging the purport is reduced to a minimum; and the author who has not a presentable idea, couched in proper terms or enough basis of thought to warrant a plain 201 


\section{The Rambles of an Idler}

statement lacks the best of reasons for attempting authorship.

It may be objected that, given a direct assertion, there may be more than one view of its significance; and the advocate of each view will use all the power of language to defend his own conclusion. How, then, it is asked, is the layman to decide when the doctors disagree? Our only hope lies in the honesty of the doctors; and this honesty is exercised only by the use, and not the misuse, of language-by admitting the weakness of one's own arguments, as well as their strength, and not misquoting an adversary or the assertion, itself, under discussion. Words, with their meaning, should be the debater's stock-in-trade-not words merely. Rhetorical flourish, sophomorical display, and lexicographic hysteria may convince for a time; but the convincement is quite likely to be that a palpable lie is the plain, unvarnished truth. Many a writer thinks he has gained a victory if he has gained a few followers ; but, is it honorable victory when the means used was verbal jugglery?

There is no disposition to decry elegance of diction. Fine raiment fits the form of Truth 
with telling effect; her beauty is increased by it; but cunning, likewise, has learned the art of decorating a lie until it, too, is lovely to look upon. The curse of it is the difficulty to distinguish between them. The unthinking crowd cannot; so much the more does it behoove honesty to deal only with plainness of speech-to call the proverbial spade a spade. Literature that is literature-the recorded thought that is to remain long after the thinker has passed away-by so doing, will not suffer. 


\section{CHAPTER FIVE}

\section{THE EXCELLENCE OF MISFORTUNE}

I know nothing more delightful than to meet with disaster. Only then do we discover our real selves. The easy-going man knows little more than his own name. I do not refer to battle, murder and to sudden death, as the Prayer Book has it, but the coming to grief of life's minor details. Carefully laid plans, for instance, however elaborate, if they meet with no obstacles, are apt to lead to disappointment. This is the lesson we should learn from the experiences of others, but the searchlight of forethought is not often pointed in the right direction. He is a truly wonderful man who does not except himself from all restraining conditions. "All men think all men mortal but themselves."

Acquisition is just beyond our fingers' ends. We must reach upward or outward, stand upon 204 


\section{The Excellence of Misfortune}

tip-toe or lean far forward, and then success crowns the effort. This is the exertion the world demands, and, though we count it a misfortune not to possess without effort, it is really a blessing. Let ingenuity die and courage languish, and we might better die with it than continue on earth. Our presence ceases to be of advantage to others. We all love to be lazy, I admit, but this is because degeneracy has set in, or development has not progressed; and indolence should not be confounded with the healthy reaction following the intoxication of success. There is a time to rest from our labors, but many labor only as an excuse for resting. Dreamland is the nearest foreign shore, and the stream of travel flows always in that direction. We incline to be lazy when the spur of ambition is dulled. We do not feel its pricking and gradually lose knowledge of ourselves. To meet with disaster is the only efficient cure.

Our first effort a success, we are too prone to be content therewith and disinclined to make a second. As if the sapling oak was so pleased with its first acorn, it willingly remained a barren tree thereafter. Such things are not known in Nature, but man, with a mistaken view of $\mathrm{Na}$ 205 
ture's methods, assumes to be something superior to her. He sets his individual opinion against the matured wisdom of the ages and errs in proportion to the inflexibility of his conclusions. The drone is a common ideal at life's outset. The worker is looked down upon. But to which belongs the honey? The drone invariably claims a share, but his argument has never proved valid. The worker is not such because the required labor is light and every flower offers honey. If this were true, labor would be only active indolence. It is failure that rouses the inborn energies, self asserts itself, pride is awakened, the real bee knows its strength, and labor is rewarded when the choice flowers are found. Moments of actual joy are worth a lifetime of theoretical pleasure. As to Nature, we receive nothing from her for the mere asking. Where man lives on the banana, he does no more than breathe. He is as soulless as the fruit upon which he feeds. To plant, to guard the growing crop, to reap, - these are the stimulating efforts that develop and make us conquerors at last. We are free to choose, but no one dwells in a palace who only dreams of marble. That hungry man who sprawled beneath the 206 


\section{The Excellence of Misfortune}

tree did not have an apple fall into his mouth. His brother, who climbed among the branches, went away filled. Did the opposite prove true, the world would not advance; and he who laboriously climbs, seemingly in vain, will reach the fairest fruit, at last.

Better than this, the wrong tree must often be climbed over. Our efforts must gain us only bitter fruit, at first. How else can we know of that which is sweeter? The world is an aggregation of comparative excellence. If our discomfort satisfied, comfort would be unsuspected. If we knew all things, there would be no effort; omniscience would reduce us to an aimless hulk. Life is a struggle to attain and obtain. Our goal is a direction, not a fixed point in space.

Defeat, disaster, destruction, despair, a gloomy procession of ill-boding words, the four walls of a chamber of horrors; but what of decision, determination, development, delight? We are free to choose. The effective sermon can come only from outside ourselves. We are children of Nature, and back to her we must turn when the path taken has proved to be the wrong one. The platitudes of brother man irri- 
tate more than educate. Back to Nature and start aright. There would be no going astray, if we remembered her teachings. Ignorance of Nature is more fatal than ignorance of man or his teachings. The oak depends upon the soil wherein it is rooted. We pull ourselves up by the roots and, teetering hither and yon, bewail our fate when a puff of wind overturns us.

Back to Nature and sink self to its proper level. There are vines that start at the root of crooked trees and have endless twistings and turnings to follow. That rebellion should be a foremost thought seems natural from our point of view, but it is not. The vine counts the advantage of a crooked path. The outlook is more varied, the experience more complex, but the open world at the tree-top is reached at last. Success that comes too early rests on weak shoulders. They bend early and age is decrepit in advance of its years.

Disaster and despair, our common fate and greatest weakness, are commonly associated in the mind, but not logically. No road is so barren that we learn nothing as we pass along. When we turn back, the facts we have gathered better fit us for the proper path. Our spent 208 


\section{The Excellence of Misfortune}

energy was not for a bauble. To despair is to call Mother Earth a fraud. Why should any one despair?
A thousand things are hidden still
And not a hundred known.

There is enough to do to keep happily busy during your remaining, rightly directed years. There is no firmer foundation than a blunder; no more hopeful remark than, "I see where I made a mistake." No other sight has such educational value. We can build on it and feel safe; but not all the superstructures of callow confidence have withstood Time's buffetings.

"I am struck," writes Thoreau, "by the fact that the more slowly trees grow at first, the sounder they are at the core, and I think the same is true of human beings. We do not wish to see children precocious, making great strides in their early years, like sprouts producing à soft and perishable timber; but better if they expand slowly at first, as if contending with difficulties, and so are solidified and perfected. Such trees continue and expand with nearly equal rapidity to an extreme old age."

The world owes no man a living. $\mathrm{He}$ is only. 209 


\section{The Rambles of an Idler}

free to get it, if he can. How best to do so, is the momentous question. I hold that the surest road to success is that beset with obstacles. I do not find that wild life, as we call it, is readily discouraged, and it is never in any sense free and easy. Man's enemies are many, but Nature's humbler children have legions of implacable foes. Man, at times, can walk in perfect peace; not so, at any time, can beast, bird, or butterfly.

Did the mouse not fear the weasel, and the weasel not stop to listen when it heard my footsteps; did the squirrel not crouch when the hawk hovered above it, and the hawk scream when plagued by passing crows, I do not know why I should walk in the fields. I am not anxious to witness a tragedy, but I am filled with excitement when the exercise of ingenuity is shown and an obstacle successfully removed or avoided. Give the world at large an easy time, and I hope to get out of it. There is nothing so monotonous as inactive life.

"So, then, because thou art lukewarm, and neither cold nor hot, I will spue thee out of my mouth."

I remember recently meeting with a superb 210 


\section{The Excellence of Misfortune}

snake. There was not a plate of its armor that did not shine, and as I drew near, it raised a threatening front. What, indeed, was I, to obstruct its path! But I did obstruct it. It essayed to pass me, but I checked its progress with my cane and sent it spinning through the air. It approached again, but cautiously, and I made ready with my cane to catch it once more. Not so. It saw my "made-ready" attitude and studied it cleverly. It made a feint to pass me on the left, and when off my guard, for an instant, darted by on my right.

Our Indians, so it is said, credited blacksnakes with greater intelligence or cunning than the other species found about here, and I am ready to believe it. I ask no better evidence of the creature's mentality than this snake offered; but the point I here raise is, that my rough usage was not looked upon as disastrous or even discouraging. It was merely an intimation to try a new method with eyes more widely opened, and the newer method led to success.

I have seen pike leap over the cork-line of a net, and once saw one burrow under the leadline. To turn back, in either case, would have 


\section{The Rambles of an Idler}

been safer, but the obstacle was met, and how far insuperable was a matter to be tested. The idea of discouragement has not yet taken a strong hold of even the lower forms of life. Anecdotes are endless as to the ingenuity of animals. They encounter as many difficulties as does man and in all probability overcome a far greater proportion. It is based on the assumption that I have argued long on the importance of studying the habits of animals that we may the better meet the exigencies of our own lives. Natural history is as trustworthy a guide as human history. The former is logical, and a long array of facts; but the latter is a record of blunders more than of great accomplishments, and so changeful is the world, the past has but little applicability to the present. This is not true of natural history. It started on right lines and has not wandered far from the desired direction. The long journey from protoplasm to man was one with little loss of time or energy through uncertainty of purpose or vague wandering in a trackless desert; but since the goal of manhood has been reached, the floundering nearly equals the well-directed purpose, if we read history aright. 


\section{The Excellence of Misfortune}

We can well afford to look backward, to go to the ant, consider her ways and be wise.

The mistakes of a lifetime are fewer among the lower forms of life than among ourselves. Theirs is greater singleness of purpose and so proportionately less risk of erroneous judgment; but mistakes do occur, difficulties confront and barriers are found set up against them. Disappointment doubtless ensues, but not despair. The brain is quickened by the test to which it is put, not rendered sluggish by despondency. Experimentation on our part shows this to be true. Interfere with a bird while the nest is being built, and we have one of two results; the structure is completed to conform to the altered surroundings, or a new site is ohosen; the purpose of nest-building is not abandoned. The "try, try again," that is dolorously chanted in the nursery, often to the child's disgust, is not needed in the nurseries of Nature. To repeat the effort is a matter of course. That life is labor is recognized by wild life at the outset of each individual's career and accepted cheerfully. We cannot always say as much for ourselves.

Throughout our summers we have several 213 
representatives of a family of birds known as the tyrant flycatchers. They are not musical, nor brightly plumaged, nor noticeable because of size or by their numbers; but greater than all these features of bird-life, they have one merit, indomitable pluck. Long before Richelieu petulantly exclaimed there was no such word as "fail," these flycatchers knew the fact and cheerfully accepted its significance. The flycatcher's life depends upon capturing fleetwinged insects in mid-air. There is equal advantage, and success by no means crowns every effort of the bird. I have often seen the pursuer and pursued darting frantically here and there, speeding like lightning, skyward and earthward, and when the chase seemed at an end, safety came to the insect and the baffled bird returned, panting and exhausted, to its perch.

A moment's rest is all it asks. There is no seductive thought that life's lines are drawn too tight. The single aim is to capture living insects, and again the bird sights its prey. Again the rapid wings are in motion, again the skillful turning and twisting and at length, success, on the bird's part, is secure. 


\section{The Excellence of Misfortune}

Compare this with the familiar, "Oh, I've tried and given it up."

I doubt if ever a fish-hawk hungered long because robbed by a bald eagle. It has faith in its resources, although they fail it at times. The eagle's back may be turned, next time, and chance has a value which is worth reckoning with; its own wings may be a match for the eagle in the next contest. At least, the bird is so far encouraged as to try again, and a fair measure of success is shown by the fact that fish-hawks hold their own against the race of eagles.

Nature, wherever we turn, tells the same story. Nowhere is permitted unobstructed progress, uniform success. This would mean stagnation. Think of the ocean without its waves. To stand long on its shores, gazing at monotony, would drive us mad. The haps are delights, but the world's mishaps, as we call them, test our strength. How else should we know that we are strong? Our good fortune bears a distinct relationship to our misfortune. Success that rests on the ruins of our failures stands upon a firm foundation. 


\section{CHAPTER SIX}

\section{UNDER THE OAKS AND ELSEWHERE}

Under the oaks! Words these that may mean much or little. It depends nothing upon the trees; everything upon the person. He who seeks the shade of venerable oaks goes to a choice sanctuary. Under the oaks of the home hillside, I replace the English colonists and likewise the Indian who preceded him. These, indeed, are venerable oaks! A century counts for little, considering the age of many into whose branches I peer as I lie on the moss that mantles their wide-spreading, twisted roots.

The oaks here stand for the eternal rocks. In the range of my ordinary rambles $I$ know of not one that is dead. They are the representative features of our fixedness. Gone, and my little world would crumble. The beeches command my admiration, the tall birches in their tattered coats are entertaining; so, too, the 216 


\section{Under the Oaks and Elsewhere}

elms, maples, persimmons, gums and spreading chestnuts; all admirable, all eminently worthy of consideration, but only the oaks inspire awe. Mankind, these later years, is disposed to stand aloof from awe-inspiring objects. They are incomprehensible and confusing to little brains and have grown distasteful to big ones. Reverential fear has lost its hold. The contemplative element of the mind is now an inconspicuous one, probably because " strained from its fair use." None but quieting thoughts should come when near an oak. No vexing problem or baseless fear should rob us of comfort when the tree's sheltering arms are extended over us. The whispering of the sun-resisting leaves should soothe us. Their message is Peace, but our ears are not always attuned to hear it. Artificiality has crowded appreciation of Nature so close to the wall, it is as thin as a shadow. Given opportunity to assert itself occasionally it has, not sufficient strength to reach to substantial benefit. I think I have known where an old oak had no significance. I know I have known where the undergrowing grass and flowers, the birds and bright blue sky, have conveyed no meaning. 


\section{The Rambles of an Idler}

Not a day in the year but an oak tree means more than one can realize. It is never enough to murmur its name and pass it by as you might some casual acquaintance. You can nod all day to an oak, but how often does the oak nod to you? When we have more oak trees, if in my time, I shall look for the millenium to peep over the hills and happiness overspread the valleys. Never a day but an oak tree is a preacher and a teacher of a worthy kind: in June, when the tree's leafy crown is in the full freshness of its glory;-in December, when its gaunt arms are still bravely extended, defying the storms that gather about it.

An oak tree in June tells a long story, but never is a word of it one too many. The eye and the ear are reinvigorated by each new incident, and there is no surfeiting. We are in a state of blissful expectancy from dawn to dark and keenly alert to the still stranger stories that are told in the moonlight. A day under the oaks is never too long; a moonlit night is all too swift of pace.

An oak tree is a home as well as a temporary shelter, for all life; a woodside inn for weary travelers. The migrating hosts of birds, in 


\section{Under the Oaks and Elsewhere}

their season, survey the country from many an oak tree's top. When the leaves are mere babies,--pink, yellow and fuzzy, and the level rays of the rising sun add to their beauty, have a host of Canadian warblers wander through the tree-top's twiggy maze, as I saw them recently, and one picture of the round year is complete. This, in May. When the bare branches of the same old oak are lined against a pitiless, cold sky, let them be suddenly flooded with the ruddy light of the setting sun and at the same moment have a goodly company of waxwings as suddenly appear, lisp a few syllables and vanish, and another story is told. This, in December.

Elsewhere, at certain seasons, the rambler's pathway may not lead to Elysium. The outlook may be depressing and visions of the fireside dim the scant merit of the out-door world. Never so, under the oaks. They are ever suffcient. They make the accessories of summer luxuries, such as they are, no hardship to forego. Many a year has passed since I learned this, and to-day, for the ten thousandth time, the Cárolina wren announced it in his masterful 


\section{The Rambles of an Idler}

way as I rested in the shade of this blissful Arcady.

Eurék-Eurék-Euréka! whistled the bird, a veritable Prince Polyglot, custodian of the charms of this ancient wood. He never asks a holiday. Summer and winter alike, he bids dull care begone, and if the rambler is willing, initiates him into the fold that know the "sylvan secrets," and, knowing, see and hear what before had not been recognized.

\section{O, many mooded Master Bird!}

Long since, the day when first I heard

Thy wisdom shouted down the glen,

Where, hidden from the gaze of men, Thou hadst thy home, Inspiring Wren;

And now, with burden of my years

No path so bright, but dimmed by tears;

Yet know the merit of thy thought,

Not vainly here, content is sought.

Still, while I linger yet on earth,

Cheer each new day as it has birth; And, as in years long gone, may we As friend with friend, together see, These blessèd oaks, this Aready. Whene'er I trace each charmèd spot, Be thou my guide, Prince Polyglot. 


\section{Under the Oaks and Elsewhere}

In a recent geological report it is stated that the largest white oak in New Jersey is nearly twenty-five feet in circumference, and its spread of branches more than one hundred feet. I remember an oak much larger, but size is not everything from a wise rambler's point of view. Much smaller trees will meet his needs, but they must be oaks. We can meet with people anywhere, but mere humanity does not suffice. We demand congeniality. To grasp my meaning better, try the trees as you find them,-maples, ashes, cedars, and then halt in a grove of oaks. Possibly the former will please, but surely the latter will wholly satisfy. That the Druids held the oak tree sacred is a myth, but one too pretty to brush aside. There is a sweet reasonableness in many a pagan rite.

I am continually told that oaks are not planted because of so slow a growth. It is not a valid reason. Not so long ago I planted the acorn that is now an oak tree, in the shade of which I find comfort. The planting of an oak is the performance of work that lasts; yet how few are planted! We are too busy with soft wood that perishes before our eyes.

Trees are ever something more than Nature's 221 


\section{The Rambles of an Idler}

most forceful expression of vegetation. Root, trunk and branches constitute the tree in that literal sense loved by laziness, but what do they stand for? They are healthy products of creative force. They honestly fill the purpose of their being; creator and created on an equality. All of that purpose is yet to be determined; but why such endless varjety? Here we can wisely speculate, for speculation in this direction leads to the upturning of many a minor fact.

I am sitting now in the shade of a chestnutleaved oak, lacking little of four feet in diameter and with a spread of branches of about eighty feet. A single glance tells me that the tree is something more than so much wood. Its story is in three chapters, roots, trunk and branches, and these we cannot dissociate from their immediate or even remote surroundings. No form of terrestrial life shuns a tree, and in South America there is a fish that climbs them. Here, at home, if life does not take up its abode in a tree, it is ever on it or under it. The burrowed earth tells certainly of more than one animal that is at home among the twisted roots. I can see one hollow that has harbored a squirrel if it does not now, and then how these crea- 


\section{Under the Oaks and Elsewhere}

tures go bounding through its branches, and, leaping in the air, clutch at the nearest twig. Always within one of falling, yet never touching the earth. That this old oak lives not wholly to itself is not its least merit. The rambler has no idle time if he keeps up with the procession, of which this tree is the parade-ground. At the foot of an oak tree is a poor place to be alone. To indulge in solitude it is better to wander through the city's busy streets.

When we know what an oak tree means to all those forms of life that gather about it, we shall know what it stands for in the scheme of creation, and not until then.

The fact that we always speak of a "sober" brown or a "dull" brown is enough to condemn the color. The witchery of pink blossoms when spring was here and the gay colors of summer were so captivating that now it is vexatious to find the landscape mono-tinted and dull brown at that. Brown is near akin to funereal black and we condemn both colors as not compatible with cheerfulness. So, I find, wags the world, hopelessly ignorant in the possession of half a fact. What of a nut-brown November day? 


\section{The Rambles of an Idler}

The gloss on the chestnut redeems the color and gladdens the eye, and thoughts of decay do not go with the blanched shellbarks that fall with force upon the sunbaked sod and roll into crisp grass covers that try my patience. When greed is uppermost, the precise tint of the treasure means nothing. A November day, in the meadows, under shellbark hickories, or in some remote upland field, under a spreading chestnut tree, offers, hour for hour, more objects for admiration than half the days since June. The crumbs from the table but vaguely hint of the feast, but this is not fairly applied to Nature's board. There is no interim when it is bare. The wayfarer can find one dish, if not a dozen, and his digestion is the gainer. A November day is not an empty one, if we only make a collection of acorns. How many neighbors have you who can name the oaks by their fruits?

The demand for endless variety is not indicative of immeasurable capacity to assimilate it. He who knows that a single grain of sand is a fragment of quartz and was once a part of a vein of glassy rock, and how it came to be what it was and is, is wiser than are those tiresome utilitarians who crowd the highways and cry 


\section{Under the Oaks and Elsewhere}

sand! sand! all the day, as if they would sell it by the ton.

Waiting for a moment until another shellbark dropped, a blue-jay perched upon a bare twig and sang after its fashion. It was a short series of discordant notes; collectively, a harsh, rattling, corvine call, and yet it blended well with the gnarly branches and shaggy bark. Coarse, but honest to the core. There was nothing for mere appearance's sake, such as gluts you in modern assemblages of men. The blue-jay is a bird murderer, but he does not care a whit who knows it. There is no stabbing in the back about him, and now that the spared nestlings of summer are all on the wing, and there is no lack of them, we forget the foul deeds, as we thought them, that so sorely vexed us in June, and take the jay for what he is to-day. No summer sky was ever a finer blue than is his plumage, and no jauntier crest ever reared its defiance. To whom does he call, I wonder, as he cries loudly, again and again, and then, hearing no answer at all, whips the idle air with impatient wings and is gone. The gentle summer shower, when every rain-drop falls as if saying, "By your leave," is all very well in its 
way, and so, too, the summer warblers, with their endless billing and cooing and languid love songs; but it cloys at last. Even if the lightning strikes near, the thunder gust is welcomed by a healthy man and the rasping cry and gruff, stringent intensity of purpose of a blue-jay find a welcome. Energy, not lassitude, is now uppermost, and better in November a blue-jay, fretful and in its way profane, than the amiable blue-bird, never of the earth, earthy.

While a single tree may profitably fill our day, it is well to keep on the move and hear more than one story; but never move for mere locomotion's sake; that is the practice of fools. A sloping bluff, which once hemmed in the river, is now a respectable woodland tract, boasting many an old tree, and not the rudest blasts of November gales rob it of all its interest. The summer birds have gone, but other birds have come ; and, better than birds, now, are the squirrels and mice, and a stray opossum and the dreaded skunk. A glimpse of any of these, even the mice, is exhilarating.

A line in the poem of creation is a whitefooted mouse breakfasting on apple seeds. 


\section{Under the Oaks and Elsewhere}

Some larger creature, probably, carried the apple to the woods. Be this as it may, the fruit and the mouse are now together, and a day's ramble is not likely to bring me face to face with anything prettier. There is no means of measuring the sparkle of a mouse's eye, but it always seems brighter than that of a squirrel, and every act of the creature is evidence of intelligence. Now is the day of their bush nests, which are birds' nests roofed and refitted for winter use. They vary a good deal, and why, if the creatures are mere machines, as is so persistently claimed? The funniest argument that $I$ heard lately in favor of a mouse being witless was that they are so easily trapped. As if the average lord of creation were not caught more than once in his lifetime.

An interesting feature in the natural history of these mice,-and it applies to most of our small mammals,-is the fact that at times they are extremely abundant and then suddenly they all disappear. I cannot determine whether they are carried off by a plague or migrate. Certainly I do not find them dead, and yet fail to discover them migrating. The short-tailed meadow mouse shifts from point to point and 


\section{The Rambles of an Idler}

squirrels formerly crossed the river in vast numbers; but the ways of mammals in Indian days are not their ways to-day. Of course this will be disputed, but disputation is as idle as the cawing of a crow ; in fact, the latter has usually more significance. No bird opens its mouth with so little a purpose as only to hear itself speak. In this matter of numbers the small mammals vary in a more marked degree than do the migratory birds. I have known a season, now and then, when I could not find a single bush nest of the white-footed mouse, and a year later they were very common. Even the chipmunks vary a great deal in this respect. I have known them to be very abundant up to the time of taking to their winter quarters, and the coming spring not one reappeared. Did they die, carried off by some plague among them; were they killed by weasels, or during the first warm days of the new year did they slink off to another neighborhood? I should be glad to know. A year ago our common rabbit was almost a nuisance up to mid-September, and then there was none. The hunters, who all summer expected much sport, were sadly disappointed. If a quickly fatal disease broke out among them, 


\section{Under the Oaks and Elsewhere}

why were none found dead? If they migrated, how did their movements escape detection? There is something yet to learn concerning the commonest forms of wild life, and the supposed purposes of many a creature may prove some day not to be the real ones.

Nature of a bright November day may be subdued, but not to the point of melancholy. The brown rushes in the marsh may not excite us to exuberant joy as they were sure to do when green in summer; but we contemplate them with interest, though they hint of death; and the chirp of the autumn bird is never a complaint that the heyday of blossom and bright flowers is over for a season. The bird is still thankful that something remains, as I find abundant satisfaction now in counting the heap of nuts that I have gathered. The bloom of every nut tree was a thing of beauty, but more so, I think, is the matured fruit to-day. Nor is this all. When the storms of winter make the night dreary, before the bright fire on the andirons it needs but one of these nuts to call up the dreamy landscape, when the meadows were filled with a golden haze and our more quiet thoughts were still of sunshine and content. 
If a thought of approaching winter intrudes at all it is when, on our homeward stretch, we hear the feeble song of mole-crickets still unsubdued by frost. A vain protest this, that frost should come at all, and a trace of sorrow overshadows us. Or, it may be, a solitary katydid struggles desperately to assert once more that the mythical "Katy" really "did," but gets no further than the name. I was amused, yet genuinely sorry, to hear again and again an ineffectual $K a-K a$ and then silence that was really sad. The few survivors of October's "killing" frosts, as they are called, have, indeed, a hard time of it, but never are they so conspicuous as really to mar the remaining glories of a clear, nut-brown November day.

He trode the unplanted forest floor, whereon. The all-seeing sun for ages hath not shone.

I, too, tread the forest floor to-day, but not as did he to whom Emerson refers. I can nowhere walk in one direction without reaching the scarred surface of the earth, where the plow and spade have obliterated Nature's handiwork. Thankful for the little that remains, I walk in circles about a few old trees, looking up at the 


\section{Under the Oaks and Elsewhere}

peaceful sky, never more beautiful than in the mellow light of this December day, or keeping my eyes close to the mottled, mossy ground between the rugged trunks of the old trees.

It is a relief to face the real creation. It clarifies thought to look at virgin soil. Go from a lumber yard to a grove, and you will know what I mean. A forest floor to-day I find more welcome than a paved street or the tiled hall of my neighbor's stately mansion. The "raw materials," as the merchant calls them, and holds them, attract me, but not after they are reduced to the conditions demanded by our imperious civilization. It is all a wonderful story, as when a tree to-day is pulp to-morrow, and a newspaper the day after. We should all glory in such a triumph of human ingenuity, and the world scorns all who cannot keep up with its progress. So be it; but I am very glad to spend an ideal winter day in the woods; to tread, as I am now doing, a trifling remnant of a forest floor; to go back to "the good old days" when Nature was not interfered with by the hand of man.

When where I stand was first a forest floor it is not possible to say. That the higher ground 231 


\section{The Rambles of an Idler}

beyond hemmed in a wide expanse of water, the river broadening to a lake, is the conclusion of the geologist, and is not open to discussion. Later the waters receded as the climate became milder and the glacial period passed into prehistory, and now between upland and meadow we have a strip of woodland. It has never been disturbed, except as Nature works changes in the land. Trees have grown, died and decayed, and others came promptly to replace them. This, the simple story for ten thousand years or more, and so it comes where I now stand there is a forest floor. The impressions of the massive feet of the mastodon, the moose and the reindeer were long since obliterated by those of the elk, the deer and the bear. The cougar gave way to the lynx, and now there are but minks, muskrats, opossums, skunks, squirrels and mice. A sad gradation from the sublime to the commonplace, but, happily, it is the same old forest floor.

December now, and the leaves have fallen. The "all-seeing" sun shines upon the ground, but there is no unobstructed glare such as at noonday rests upon the fields. The interlaced branches of the oaks cast many a shadow, and 


\section{Under the Oaks and Elsewhere}

few are the rays that are not shut off by the spreading crowns of the beeches. There is little grass, but much moss, and this so gray that it suggests old age. There are few annual growths, and these not always conspicuous. The wind spitefully heaps the dead leaves over many a blossom. Bluets and claytonia in spring, asters and goldenrods in autumn-these come and go in their seasons, but there is always the gray moss, that yields softly to my step, like tufted carpet. There is no jarring, no noise, save when dry twigs are snapped. I can pass from tree to tree as silently and swiftly as an Indian, disturbing nothing, distracting no bird in the branches overhead and scarcely noticed by the mice in their runways that cross my path. To be here is a delight at all times, and as pleasant now in December as when the world was all astir. This is a hazy, meditative day, and the forest floor tells its story more plainly than it could have done above the songs of summer birds. The facts are now laid bare. Here and for miles around the bedrock is deep down in the earth, and we have only sand and pebbles, with an occasional bowlder of pretentious size; but few are the trees that because of 233 


\section{The Rambles of an Idler}

a sandy foundation have found themselves seriously shaken. The surface is stable. Not all sand is forever shifting. There is no evidence of change except of minor extent, as an occasional landslide of a few yards. The roots of the oaks have defied the wind and rain. The soil is poor, as soils are considered by the agriculturist. Neither grain nor vegetables would grow here, even with abundant sunshine and moisture to urge them on; but trees have grown and are now in full vigor. Some of the oaks were acorns more than two centuries a.go. There is surely some hidden source of fertility that sustains the forest, and barred by the shadows of its leafless branches is that floor which to-day is so inviting. Moss bears the relation to grass that age bears to youth, or as sober contemplation to the passing idle thought. Moss is as dignified as any aged oak. They are congenial friends, seldom apart. What the tree is to the landscape, so is the moss to the ground upon which we tread.

But there is more upon the ground than moss. Looking yet closer about me and recalling very distinctly what I have seen at other times, I find much that should be mentioned. The acorns 


\section{Under the Oaks and Elsewhere}

that fell a year ago and escaped squirrels, mice and worms, are now pretty stems, half a foot high, and with two broad leaves. In spots hundreds of these hide the moss, and, pigmies as they are, make a bold front and stand ready to possess the land. Elsewhere I see little, low bush huckleberries, very pretty in their blossoming days; and nearby is spicewood, beautiful when its golden bloom sparkles through the April woods, fragrant at all times, and still partly in leaf. It is a shrub to remember when you brush its twigs aside, and, bruising its leaves, find your hands scented with the refined essence of long summer days; an odor equal to conjuring up all the glory of the past.

Where now there are but crushed and withered leaves I see as distinctly as ever the cypripediums, their strange, mottled purple blooms brightening the gray moss about them. Rattlesnake plantain, too, and rattlesnake weed more abundant and quite as pretty. Very barren, so it is said, is this mossy forest floor. I have heard this said by more than one person while they stood in the shadows of the old oaks and had all this royal bloom and shrubbery about them. Surely stout timber is a goodly growth, 


\section{The Rambles of an Idler}

and an orchid that gives rise to a pleasant thought is not to be despised. I doubt if a field of corn is the climax of the earth's ambition.

Much besides moss is here, really, but the latter is everywhere rather conspicuous. True greatness is never overawed by the clamor of the insensate crowd, and so with the moss upon the forest floor. The mature fruit of a century stands for more than the quick growth of a season. It has a seigniorial right no upstart can successfully dispute. Better a handful of moss than a cart-load of weed.

In the minds of many, all that I have said will not suffice to drive away the impression that a forest floor is monotonous. Accepting my facts, if not my philosophy, they will ask, "What next?" I fear this eagerness for abundant novelty is not always indicative of vast assimilative power. All that a forest floor stands for is not realized in a moment. It should stimulate thought rather than please the eye; but this is too prosaic a view for the onrushing sightseer-seldom a seer in any other sense. However, if variety must be had, here it is in the damp earth, where the waters of a struggling spring have vainly tried to form a 


\section{Under the Oaks and Elsewhere}

little pool. There are not a dozen drops of open water, but dampness only, yet it is worthy the rambler's closest attention. It means a few ferns, by way of variety, and, though small, they have been pretty and are attractive still. They have a leathery feel, and the vigor of early May has departed, but they are ferns and all that these growths signify. If we truly love a plant, even its picture will command attention. Here are only faded, leathery ferns, but who has yet to learn that beneath a wrinkled skin there is abundance of life? Too pronounced freshness is occasionally open to adverse criticism.

Given vegetation, moisture and alternate light and shade, animal life without stint will crowd the spot. The dry moss seemed deserted as I looked over it. A lazy spider, shining coal black ants and inert beetles were all that I could find in the way of animal life, but about the ferns and in the moist earth were many and widely varied forms. A frog, a salamander and a baby turtle had gathered here, and a chattering bluejay directly overhead seemed to be scolding because I kept it from coming to drink. A less cautious chickadee came quite within my reach and a squirrel scampered by, barking 


\section{The Rambles of an Idler}

spitefully. I had trespassed upon the common domain of the wild life of the woods, and was reminded that man is never one with the creatures whose company he would keep. This common domain was a damp spot only, yet treasured by the creatures that here slaked their thirst. How they found enough water to drink I cannot imagine. So far as I could determine, here was dampness merely; but, then, I see only with my own eyes, which doubtless would be thought a pitifully poor way of observing Nature by every beast, bird and creeping thing that lives in, on and above this forest floor.

If it were possible to follow the same path, at the same time of day and tarry for a few hours at the same spot; if this were possible for a year, in shade and sunshine, under clear skies and cloudy, summer and winter, then and then only would we have a clear conception of what a trifling bit of commonplace country really is. Then, I believe, the comedy and tragedy of each day as it passes, might be recorded as it should, clarity of thought following contact with Nature. 


\section{Under the Oaks and Elsewhere}

To take the same walk daily is not a monotonous, dull round as when we hurry from house to office and return. We need but to try to prove this, as when I took the same path for five successive days in early spring. In the brook I saw minnows with gorgeously tinted fins, and their brilliant color brightened the outlook whichever way I turned.

Where swarms of minnows show their little heads

Staying their waving bodies 'gainst the streams,

To taste the luxury of sunny beams

Tempered with coolness. How they ever wrestle

With their own sweet delight, and ever nestle

Their silver bellies on the pebbly sand!

If you but scantily hold out the hand,

That very instant one will not remain;

But turn your eye - and they are there again.

See them as Keats here describes; this needs no cunning of a trained eye and the subsequent vexations of the day will be softened to a more endurable degree.

The second day, the bridge pee-wee was perched upon a bare branch of a horn-beam overhanging the brook and its simple song called back a teeming past as well as foretold the wealth of a coming summer. Other birds 


\section{The Rambles of an Idler}

that way. The chain of events had not been broken, but of the thirty links of that month, I had only five. Enough to show how much I had lost, if nothing more. But five days afield ought to prove something more than the record of so many trivial facts. What of their significance? It is a sorry ending of a ramble if we can recall only the fact that we were out of doors. All the meaning of an occurrence is not apparent at the moment it took place. Usually but little of it is realized. The incentive to seek adventure is the subsequent conversion of the event into subject matter for thought. Only thus is Nature made clear and man methodical.

The impression of a fact is of as much value as the fact itself, and it is not enough merely to state it. Facts need something stronger than a bold statement to make them clear to another. A fact, without an opinion, will call for no opinion on the recipient's part. It is ever the narrator's attitude towards the fact that stimulates a reader and leads him to put himself in the author's place. Were this never true, a book about Nature would be a waste of ink and paper. It is true, we are not concerned with the merchant so much as with the quality 


\section{Under the Oaks and Elsewhere}

moved me to turn away until the brave crested tit called me to my senses. It would be better for us, could the fact always be remembered that there is no better medicine for winterweariness than the trifling green of an early April day.

The fifth morning, I found a dew-spangled spider web, so substantially woven that it distinctly resisted my finger as I pressed against it. It was a large, apron-like platform gently leading to the spider's den and the creature herself, though in full view, was very inconspicuous. Her neutral tints blended with the surroundings in most skillful way, her legs appearing to be so many bits of dead grass, and her body, a withered leaf. The web glittered in the sun, for countless minute dew-drops were scattered over it. Evidently the spider was still waiting for her breakfast or there would have been evidence of commotion. Insect life, evidently, must be active again, yet I had not noticed any fly or beetle. This web, beautiful in itself, was not forgotten all that day. Until the goal was reached, it held my thoughts, as when flies struggle hopelessly in its mazy toils.

Almost a month passed before $I$ was again 241 


\section{The Rambles of an Idler}

that way. The chain of events had not been broken, but of the thirty links of that month, I had only five. Enough to show how much I had lost, if nothing more. But five days afield ought to prove something more than the record of so many trivial facts. What of their significance? It is a sorry ending of a ramble if we can recall only the fact that we were out of doors. All the meaning of an occurrence is not apparent at the moment it took place. Usually but little of it is realized. The incentive to seek adventure is the subsequent conversion of the event into subject matter for thought. Only thus is Nature made clear and man methodical.

The impression of a fact is of as much value as the fact itself, and it is not enough merely to state it. Facts need something stronger than a bold statement to make them clear to another. A fact, without an opinion, will call for no opinion on the recipient's part. It is ever the narrator's attitude towards the fact that stimulates a reader and leads him to put himself in the author's place. Were this never true, a book about Nature would be a waste of ink and paper. It is true, we are not concerned with the merchant so much as with the quality 


\section{Under the Oaks and Elsewhere}

of his wares, but the wares of an author are not so separable. The author makes or unmakes the facts he gathers. Freed from his attitude towards them, from his enthusiasm and impressions, they remain as nuggets of gold awaiting the artist's skill to give them comeliness. Eliminate the personal equation and Nature in a book is paralleled by Nature in a museum. Specimen facts are very like specimen stuffed-birds or minerals in a case.

Pope, in his earliest version of the Essay on Man, has the line:

A mighty maze of walks without a plan.

That is what the earth is apt to be, but the fault is our own. Walking without the art of walking is much like a corpse as compared to a living body. Whether mechanical or not, is the question, and if not mechanical, but spiritual to the extent of discerning the purpose of that which is seen, then we do not walk in vain.

To enshroud in mystery is often but to wrap yourself in ignorance. Call a thing mysterious and there is no incentive to investigate its true character. It is the common way of excusing 243 


\section{The Rambles of an Idler}

lazines We do not feel called upon to solve knotty problems or to attempt the impossible, as so much becomes when we deepen the mystery that surrounds the outlook. It never occurs to us that all this is but a process of our own mind. We ascribe to Nature what does not belong to her and simply render ourselves more and more helpless as we stand gazing vacantly at what transpires before us. The ascription of mystery is a cunning device of lazy humanity.

The sense of ownership is a pleasant one; the impression of the superiority of our possessions is not belittling. It is fortunate that the even greater luxuriance of your neighbor's fields is not apparent to you, for where envy enters, peace of mind departs. Only feel that you are particularly blessed and it is a fact that you are reasonably fortunate. In short, treasure your trifles as though they were unique gems, for it is only through such intensity of interest that positive value becomes apparent. Distance should not always be allowed to lend enchantment to the view. The battle of the ants that Thoreau witnessed was as tragical as any massacre of innocents or any war between 


\section{Under the Oaks and Elsewhere}

nations, and occurring near home, of more importance. I have never found the world empty where the traveller remarked contemptuously that all was tame. Per contra, some of the most superficial people I have ever met have been the farthest travelled. They had never. seen the real countries they had crossed. Their desert of Sahara and my sand-dune in the field corner differed only in size. The real difference they never suspected.

As I walked by the creek-side this morning I saw a pike dart like lightning from the lily pads and I knew there was one minnow less in the little school wandering up stream. Looking across the meadow, I saw a hawk carrying off a mouse, and later, in the dusty wood-road, met with a wasp that dragged along a huge worm, many times larger than itself. I looked in vain for the comic side of Nature hereabouts. All was serious, and to keep light-hearted I had to overlook the actual conditions. I could have witnessed tragedy all day and even been a participant in more than one fray, had I chosen. It may be very tame here at home, but disturb a nest of yellow-jackets and there is excitement 


\section{The Rambles of an Idler}

and danger equal to facing the average wild beast. I do not underrate the desirability of travel or of adventure in some far-off land, but while content at home have no longing for wandering beyond nightly reach of my den. Let the Antipodians glory in their Antipodes. Some trifling bits of wildness are all I have, but while I have them, let me believe they are still genuinely wild and the old oaks not yet deserted by the good god, Pan.

Expectation, based upon hearsay, has usually a sad ending. Fancy has only un-real colors on her palette and paints a livelier rainbow than Nature allows. So, it is well to curb our enthusiasm when recounting our experience, lest our friend think we have found a real diamond which, in truth, is but paste. But, if we disappoints others, as surely others disappoint us and the honors are easy. I have been induced to travel far to see that which failed to interest me and have brought others to some out of the way nook in which I delighted, only to vex them sorely over their loss of time. It is far better to keep your discoveries to yourself and save being laughed at for retaining a child's enthu- 


\section{Under the Oaks and Elsewhere}

siasm over little nothings. It has taken some time to be convinced of this, but now I am firm in the belief; and because the world at large cares nothing for some meadow ditch or nameless upland brook, I do not propose to abate one jot my enthusiasm for what I find, even here where nobody comes and all is tame.

Over the range of my rambles $I$ found the marks of the coming and going of destructive men for more than two centuries, until almost nothing was left, as Nature would have it. Then, the place was forsaken of men, and while their backs were turned, Nature repaired the mischief and beckoned to me to come on. Strange to relate, there seems to be a good deal to occupy one where the traveller had proclaimed that all was tame. Where bigness only counts, we are more apt to be excited than satisfied. Fever heat is exhausting, not exhilarating and the re-action to commonplace conditions too great a change: it proves a shock. We do not need the element of danger or intense excitement to make life enjoyable. As well claim the necessity of alcohol to aid digestion. The acorn still sprouts in the way it always did and not a minnow in the brook but 
swims according to the rules laid down for the huge fishes of the sea. We may drive off all our bears, but there will be a raccoon in some hollow tree. Beavers are long gone, but there is the musk-rat. There never was a neighborhood that did not contain one real, live hunter who could make his living. The later, cheaper edition tells the same story as the first, with its abundant, full-page illustrations. Even here, where all is tame, there are mud and water and weeds just as Indians found them when they wandered about, and such as the Dutch and the Swedes and the English saw when they went up) into the land and took possession thereof. Here, I regret, even from my own point of view, all is tame, but compare it with brick pavements.

If all is tame in a long settled country, please always to remember it is even tamer when people are about. Visit a trim woods when noisy with a picnic and go afterwards alone to the same place and you will know what I mean. A tree, a bird and a cloud-flecked sky to yourself half-way meets with your demand for wildness, but you will never find a trace of it even in the country, remote from town when a bab248 
ble of men's voices drowns the babble of a brook.

Where all is not tame, the wildness is too pronounced to conceal itself; but here, where all is apparently shorn of its savage or natural state, the greater tax upon our cunning to discover the little that is left. The plowshare never invades the very edge of the brook's bank, so there is a little strip of earth that is left in peace and the water that ripples by the sunken root of an old tree, runs in the same twisted channel as water found perhaps several centuries ago. Here then is a chance for profitable idling. Turn a little brook inside out and you have built a museum. Surely, sufficient unto each day is the wildness thereof.

As the sun was setting yesterday, the sand at the water's edge was as smooth as the paper upon which I am now writing. There was not a line or a dot upon it. Now, twelve hours later, it is covered with foot-prints of several kinds and yet we speak of this spot as one where all is tame. It would puzzle the most practical hunter to trace back to its lair each of the creatures that came here in the night and it 
would have been excitement, instruction and keen pleasure enough to have witnessed what so lately happened at this most commonplace spot. Go to distant lands, if you will, to outwit great beasts, but all the while a young rat under your door-step, is outwitting you. Adventure is at its best when human and brute wit have a battle royal. Bullets and bigness may prove very tame-mere butchery generally, for hunter and game are seldom equally matched; but armed only with dexterity and such other gifts as Nature has vouchsafed you, try your hand at capturing a chipmunk as it darts along an old rail fence, and the chances are, if you are candid, that you will entertain some wholesome thoughts before the adventure is over.

Lead your coveted game into a trap and you have cause for gratulation, but look out that you are not led into one. I have never seen greener grass than that mantling a quick-sand.

My interest is ever aroused by foot-prints, especially such as crowd every little mud-bank, like the one about which I so often linger, and have lingered, these many years, yet have not learned all they have to tell. Foot-prints are 


\section{Under the Oaks and Elsewhere}

as suggestive of poetry as the transient thrush is of a summer song; yet we are apt to pass them by as mere chance markings of the impressionable soil, and proceed in thought to other and less weighty matters. Let us give over for the present contemplation of " footprints in the sands of Time" and consider those in a narrow strip of mud. To decipher them, is no easy task. The hunter may know the tracks of the game he seeks but here have passed small deer quite beneath his notice; and let it ever be borne in mind by him who loves an outing that where everything is tame, the interest decreases with the size of the footprints. Persecuted game and persecuting gunners are alike unattractive. The one has lost through fear all its naturalness, the other his better elements of humanity, so we will dismiss them for the present.

The foot-prints before me now are in such bewildering confusion that to report them all is impossible, but here is the impress of a large turtle's foot and clearly a tail mark besides. Crossing its trail, a meadow mouse has hurried by. Beyond, a little way, a small snake has crawled ashore and in its course, partly rubbed 
out the footprints of a spotted sand-piper. The green heron and purple grakles have been here and little curved lines, diminutive crescents in orderly array of pairs, suggest that a mud-minnow rested at this place on its fins, before the tide ran out. Still smaller markings are a matter of doubt, but many aquatic bugs and spiders run lightly over the shining mud and leave faint traces of their wanderings. At least one frog has been squatting here and left a body print, and if I had not seen that a shapeless depression was made by a grasshopper while still floundering in the mud, it would have puzzled the most clever paleontologist to decipher it, had it been fossilized. Five or six representatives of the great divisions of life have passed to and fro in the night, and now, not long after, I see but a single sparrow, hear a crow in the distance, and observe no other evidence of animal life. Here, truly, not only is all tame, but almost lifeless, judging from the present outlook; but what a different story is told by the footprints in the mud, the narrow strip of bare earth hemming in a little meadow brook.

Having taken the initial step of determining what forms of life have been here, there is an252 


\section{Under the Oaks and Elsewhere}

other to be taken, but with extreme caution. This is, to determine the purpose of the creatures that have passed to and fro. Usually, there is nothing to guide us in this investigation, for if any struggle has occurred, the mud is simply so beaten down that all traces of what really happened are destroyed. We pass from the acquirement of a fact to the realm of conjecture, yet we know tragedy is constantly occurring. It is the search for food that prompts an animal to move from point to point, and why we see so little evidence of struggle is because each creature knows its enemies and is ever on the alert to escape. To kill and not be killed is the burden of the single song sung by all creation.

Probably tragedy is writ large wherever there is great confusion of footprints, but occasionally there is a hint at comedy. Play, as we see it in children, is common to other than human life. Why should not meadow mice dance by the light of the moon? Chipmunks play "tag" and blue-jays are graceful in a minuet. 


\section{CHAPTER SEVEN}

FROM PILLAR TO POST

The strange fancy for saints' days! He or she is a poor saint who is not entitled to all the year, and, if really worthy of remembrance, to be held in admiration at all seasons. I know not whether any saint is peculiarly honored today or not. My calendar, with its trifle of advice, says May 9th, and suggests going out of doors.

I note, while standing by the door-yard elm, that the warbling rose-breast, from his lofty perch, tells the whole story of this month of May. There are few men that do not need an exemplar and I am thankful not to be an exception. This paragon of song-birds gives me the hint. All I need to be happy is to whistle as I go. Not to disturb the silence by blowing through pursed lips, but letting the heart beat to a merry tune. Many can please themselves and not vex others, by thinking their music. As 254 


\section{From Pillar to Post}

I walk, the wild birds shall be my spokesmen. Never a saint lived that equals them.

There is an exasperating clique in the world that delights in telling you to laugh at ill-luck and continue trying. Close inspection of their own careers usually shows that they have had no ill-luck worth mentioning, and, worse yet, have accomplished next to nothing, but set up an appearance of grand success by the aid of gold that they did not earn. He who is heaviest gilt is ever readiest to give advice.

What is called "ill-luck" is the insurmountable wall that confronts us when we start in life in the wrong direction. Success or good luck is wholly due to facing right at the outset. How to discover the proper direction in the beginning of a career is the most valuable knowledge the world can possess, and, it may be added, regretfully, does not possess. It would do away with unhappiness, would open the eyes to every quicksand, and there would be not an obstacle in a path unprovided for before it was reached. There would be an end to preaching; life's complexity would become simplicity; there would be a new world, that ideal one 


\section{The Rambles of an Idler}

which has figured in philosophic heads but never materialized, and probably never will. Why, then, not take this earth as we find it, as the birds are doing this splendid morning, and believe that life is labor, fortune fickle, and nothing worse can follow when our round of days is at its end? This is a comforting thought, and if it had only occurred to remote ancestors, a little nearer Elysium would be our present-day condition.

"The virtue of adversity is fortitude," said Bacon; but who wants to be brave on an empty stomach? Adversity robs life of its sweetness, its juiciness; it converts it into the squeezed rind of a lemon and, when thus reduced, why should it put on an air of consequence and exhibit fortitude? Does this "virtue" smooth the wrinkled skin, fill the veins again with sap, make the body comely in appearance and something again to be desired? Not a bit of it. It merely keeps the coals of consciousness alive so that they accentuate misery and prolong an undesirable existence. If life is constant battle, as some one has said, it is certainly not worth living. 


\section{From Pillar to Post}

I find, where I walk, a rusty pan among the dead leaves and a vesper mouse has made a snug home of it. It suggests that the art of much comfort from little is better than supposititious ease from much. He really does not enjoy Nature who demands it in excess, and must have oceans and mountains, and spurns the modest hills and wood-girt ponds that are round about him.

When the tide turns, as it so surely will, what a sorry spectacle presents itself! We are hopelessly miserable because our riches have taken to flight; for the time, priding ourselves upon our independence, but proving sadly dependent after all. Nothing of all this is seen here on this hillside. The blue sky and snow-white clouds are emblems of peace. The fresh green leaves are even merry, as the sunlight seeks them out. They flutter, not in fear, but with delight, and what a hymning of Nature's majesty when thrush and oriole, robin and bobolink, give way to the joy within them, and every breeze is laden alike with music and the breath of flowers. It is well not to be envious, but other forms of life have much to commend them. 
I have known those who had the merit of being great in their littleness. What they did, they did well. A community made up of such men is as useful as congregated geniuses. Any one of these may set a complicated work in motion, but earnest, though less gifted, men are needed to keep it from going astray or stopping: for want of trivial attentions. Because there is nothing extraordinary about the most of us is no reason for thinking little of ourselves, and, above all, for being envious of those who have accomplished wonders. That place is honorable always, the outcome of which is the result of honest endeavor. The fruit of effort in a small way is not always small. Tender vines bring forth big pumpkins.

Men are to be judged not alone by the company they keep. There are other evidences of whether a man is as Nature proposed or as misguided artificiality makes him. Take a look into the house in which he lives. I have always thought that the inconsequential carelessness of trifles out of place give a home-like appearance to a human habitation that spick-and-span order can never do. The healthy man lives not 258 
as if merely a machine; so why should his place of abode look like a museum with its treasures in fixed and unvarying positions? As the pinch of salt at a feast, so a dash of carelessness adds to the piquancy of a life.

Universality of assent is not evidence of truth. Once upon a time it was universally conceded that the earth was flat. So, to-day, we have it dinned into our ears that woe betides the hindmost in the race, and to be up and doing is the paramount evidence of excellence and the only way of making reward a certainty. Start men on the subject and their speech runs into sermons, lectures and dire prediction. It is all very discouraging. The idea of rational enjoyment must be postponed until we are overburdened with acquisitions and our proper selves stiff-jointed and dried until there is no response to the invitation of Nature to be, not up and doing, but out and enjoying. Youth is too often a vaguely remembered dream before manhood has had time to assume authority. To-day the single aim of life is to get: no longer is it the art of living.

Hare and tortoise: an old story, but never 259 


\section{The Rambles of an Idler}

outgrown. It is more applicable to-day than when Assop told it. It happens that an occasional hare reaches the goal, but everywhere lie the rotting carcasses of failure. The plodding tortoise picks his way over them.

A great city is a necessity, and so, too, are the great guns in a fort. Neither are to be played with. The village need not hide its face because, once a day, the stage-coach still stops at the post-office. Yet a little farther : the farm need not be jealous of the village. Its individuality rests on a broader base. He is as much a success in the better meaning of the word who tills his fields as is the master of a town lot. It is true many a man is but a speck on his farm and the least missed of all objects when he leaves it; but the farm is not at fault. Nature turns us out in the rough and it rests with ourselves how we are finished. There is no divinity except in ourselves to shape our ends. The field and wood and meadow can overwhelm us or we can tap the well-head of their secrets and be crowned their master. The chances are in our favor. Nature is not jealous of our efforts. At times she looks kindly upon them. In the 260 


\section{From Pillar to Post}

country we have freedom to work our will. Who can say as much of city-life?

It is a matter of taste whether we choose the city or the country, and happily we are free to choose; but why the city assumes superiority and presumes to dictate is a problem yet unsolved.

This is a perfect afternoon. The earth rests content with what has been accomplished, and the rank growths that for months struggled to conceal the scarred meadows have succeeded, and now rest, crowned with purple and gold. There are the vervain, dodder, scarlet lobelia, eupatorium, mallow, cone flower, sunflower, bidens and sneeze weed, an almost endless series of stately blooms that now give dignity to the matured season, yet not one awes the myriad forms of life that here find their home; for since the glacial floods retired and the blessed sunshine warmed the turf, there has been an endless struggle between plants, as well as animals, to maintain a roothold and a foothold here. This beautiful meadow is one of Nature's garden spots, and this is a perfect afternoon. 


\section{The Rambles of an Idler}

Nature does not demand silent adoration. Grand as is the outlook in all respects, no creature is awed to the point of silence, nor is there blank astonishment because of the magnificence. It is no transient phenomenon. The greater the brilliancy of a sunset sky the more quickly it fades; but here is equally lavish display of color, which is not evanescent. It is here to be enjoyed, and stays long enough to color our thoughts, to teach us, if we are willing to be taught.

From every foot of ground rises that rhythmic stridulation of the mole-crickets, which, heard from all sides, is as the meadows breathing. I look to see if the sod does not rise and fall as the pulsing sound swells loudly or almost dies away.

Difficult as it is to define and hopeless to describe adequately, an unmistakable presence pervades the meadows now. This vast sheet of color and accompanying volume of sound unite to exert a controlling influence over all life within its bounds. We, too, feel this influence, if in a proper frame of mind. 


\section{From Pillar to Post}

The crow wanders from the leafy wilderness of the tree-tops, circling in mid-air as if without a purpose, and only hurries away when viciously attacked by a king bird. The redwings, that have recently gathered, come from many an upland swamp, leisurely seeking the tidewashed marsh, and exert themselves no more than feeding calls for. The uncertain robins still question whether it is time to give up their summer habits, but finally unite their forces, and, as an ill-formed troop, go bungling along over hill and dale. The bobolink of springtide days is here again, but, in the sober guise of a reed bird, utters only a single note, not so much an eloquent lament on the passing of summer as it is a voicing of August's meditative days. I know it, above many another, as a bird-note that leads to retrospection on my part; sober, sad retrospection formerly, but not so now. I no longer wish that summer lasted through all the months. I follow now the example set by the blue birds that throng the air. Whatever the time of year theirs is a hopeful song. A change continuous from grave to gay, but no such dark foreboding as from life to death. August now, and nearing the end of summer, 


\section{The Rambles of an Idler}

but neither the month nor the season calls for a funeral hymn. It is only wise to say "Goodbye," expecting a quick return. With the eye of faith we can detect a ray of light in all the thick darkness we meet. Looking backward, it was but yesterday that it was August, as it now is, and why, looking forward, should it be a longer time before it comes again? This is a perfect afternoon, and if the last of such for the passing season, it is not a long waiting, and never an idle, objectless one until August comes again. Nature is a long series of events crowding each other, not as single beads on an interminably long string. A perfect afternoon, typical August, with activity everywhere, but not that nervous hurrying to and fro of early summer. Leisured activity, rather; the studied movement of age, not the rash impetuosity of youth. We see, in June, more than we can comprehend. In August we comprehend more than we actually see. Facts so crowded we fail to detect their significance, in early summer; significance and fewer facts, now. June-August. It is and it has been. June, the present; August, the past tense of summer. Recall the season in mid-winter and see how true this is. 


\section{From Pillar to Post}

Had we never heard the songs of birds in May, songs anticipating the triumph of love, or listened to the songs of June, the grand chorus of love triumphant, we should find no lack of merit in the quiet melodies of an August afternoon; but Memory holds us to the past with the grip of an iron hand. We hear, but not without keen recollection, of an earlier song. This is sobering, but not to the point of sadness. We are not cast down, but walk at a slower gait. We contrast all we see and hear with all seen and heard. It may not be what we wish, but there is no escape.

The meadows this afternoon were less of the earth, earthy, than usual. It was dreamland rather, and, walking thereon, I was less a rambler than a dreamer, and as such I reached the wooded slope that hems in the meadows. The shade was refreshing, but not so the absolute silence. Not even a leaf on the aspens trembled. The oaks and the beeches were motionless, fixed as the very earth itself. I became impatient. Life was very real again. The heavy hand of sober August thoughts was too hard to be borne, and to see a bright red leaf 


\section{The Rambles of an Idler}

of a gum tree falling slowly to the ground was a relief. Was it the signal for a coming change, I wondered? Whether that or not, straightway I heard the sharp chirping of a thrush.

It was not the lively note of early summer, a response to its mate or a warning cry to its nestlings, but a fretful, labored attempt to give utterance to disquieting thoughts. This chirp at other times is the prelude to a song, but would it prove so to-day? I listened long enough to become thoroughly doubtful and impatient. The influence of August does not quite subdue the "old Adam" that is in us. I could have thrown a stone at that irritating thrush. Even its chirp was but illy uttered more than once, but then after a suggestive pause I heard a few sweet notes.

How quickly came a vision of June days! Sunrise, when all the world was merry at the thought of day; sunset, when all the world was glad to rest from the long hours of merriment gone mad. A few sweet notes only, and I was young again. Now would come once more the 266 
whole-souled summer song, I was certain, and listened eagerly, peering into the thicket before me. But no, there were but those few notes; not loud, not exuberant, but full of depressing suggestion. Summer was past, as the thrush saw the world about it. The bird knew full well the meaning of that colored leaf, of the wilderness of yellow bloom that canopied the brook, of the purple veil thrown over half the wasteland: It felt, too, the trifling trace of chill that came with the evening breeze. The happy days were over. If it sang at all, it would be to drive away dull care; whistling to keep up its courage until it, too, left its home and all the happiness of a short-lived summer.

Farewell, the greenwood tree,

This shady dell;

This home, so dear to me,

Farewell, farewell.

Then, briefly, the thrush was roused by its thoughts to a somewhat livelier mood, and the song of June was sung as in other days; yet not quite the same. I could not be deaf to a trace of sadness running through it all. There was now left no fresh, green leaf, nor even one 267 


\section{The Rambles of an Idler}

glittering dew-drop, nor violet on the still green, sunny slope; why should the bird rejoice? The song shortened to a few brief notes, a meditative strain eloquent with thoughts of happier days. Then, silence. I had heard the thrush's last song.

I am always active when there is work to do: I run away from it; yet it is intimated that I am lazy. Not only is this activity on my part, but it is speedy. Not unwise haste, either. I protest against being adversely criticized.

Long ago I gave up serious undertakings. When I was through, as I supposed, I always found there was something yet to do. There was no exception, and I did not propose to battle with a law of Nature. I resigned activity of my own initiative and ever since have been an advocate of ease.

We contemplate the ideals that unwittingly arise in our minds. I think no one says to himself, "I will be a model," but, "I will model myself after"- such an one. It is so much easier to follow than to lead. It taxes both mind and body less. Whom I copy is nothing to others, but I do copy. He was nothing if 


\section{From Pillar to Post}

not original, I thought. I know better now. He was but the fruit of observation and reading, as was everybody before him and since. Adam copied the animals and learned many a lesson from the trees; otherwise he would have proved a flat failure. Absolute originality is only an ideal. I follow in footsteps that pressed the sod a century ago, and sometimes, as my reward, fancy I echo him who has been gone so long. I find myself stopping, looking wise and feeling really happy, as though perchance I had a worthy thought.

It is not altogether true that, being finite, we can have no conception of the infinite. It is readily understandable that there is no limit to space. There may be a limit to the number of celestial bodies, but no boundary to the space they occupy. Of whatever point some one should say, "This is the limit of space," there, it must be admitted, is an outside as well as an inside of the boundary. In human affairs it is the same story on a ridiculously small scale; everywhere stand the suggestive outposts marking what is before, not what is behind, them, 


\section{The Rambles of an Idler}

I love to live on these outermost bounds of habitable earth. The interior everywhere soon grows commonplace, but there is freshness and novelty as we wander from the centre to the circumference. There is more to see. People are all well enough in their way, but, as a struggling crowd of strangers in a town, the most tiresome objects in the world; while life, as I view it, is comfortably near to Nature at the outposts. We can see farther ahead, there, than we dare venture, but the desire to explore, ever uppermost, has chance for exercise. So, to-day, had I been in town, I would have heard the street-cars rattle; as it was, out of it, at an outpost, for the town can be seen by looking backwards, I have Bob White whistling at my elbow, and thrushes, finches and warblers all a-tune, with the twittering swallows to fill in the chinks when bird-song fails.

"In this pleasing . . . wood-life . . . let me record day by day my honest thought without prospect or retrospect, and, I cannot doubt, it will be found symmetrical, though I mean it not and see it not. My book should smell of pines and resound with the hum of 
insects." It is never safe to quote Emerson. All that follows suffers so much. Too like a jewel that has fallen into the mud; but, presumptuous as it may seem, I had thought his thought and crudely set it down before I had met it in "Self-Reliance."

How is one's book to be made to smell of pines? No treatise on literature sets forth the secret. I know that years ago I sent an essay on a brook to an editor and he suggested that I must have seen a brook after a protracted drought, for what I said of it was dry as dust. I have no exalted opinion of editorial omniscience, but probably in this case he was right. A sworn-off, bibulous husband took a glass of beer now and then, during his wife's absence, but the secret indulgence was discovered. She smelt it in the ink, when he wrote her a letter. We are too sober when we record what we have seen and heard. The intoxication of the passing moment should be riotous within us when we record not what we have witnessed but what we are now seeing; our eyes not on the paper, but the object. Let the pen or pencil take care of itself, and if held by the fingers of genuine merit, they will do so. The eye and the ear 


\section{The Rambles of an Idler}

have so much that is spiritual to concern them, the mechanical device of writing should not encroach upon their time when out of doors. Let the fingers limp over the note-book as best they can. Time enough later to interpret your hieroglyphics. In such a way, perhaps, a tree-smelling book can be made. Memory is treacherous. She can plan our discomfiture in short order.

If we cannot bring back the dead, we can recall the past, even a past of which we previously had never heard. Here I stand on the slope of gently rising ground, looking up and down a valley of incomparable grace. Below me, only a short distance off, ripples a little brook. The shallow water spreads like a sheet of glass over a floor of pebbles. It is a live brook, and to-day sings the pretty song it sang two hundred years ago; sings it to me as it did to the Indians for centuries. The mellow sunshine and October's scarlet leaves do the best they can to hide the ugly scars that come from man's assault upon Nature, for this valley of to-day was yesterday a prosaic mill-pond. Illluck for its owner, but good luck for me, that the dam is gone and the blessed sun again sees 


\section{From Pillar to Post}

earth which for two centuries has been drowned. The corpse cannot be revivified, but Nature does what she can. The sun dries the sodden mass of mud; the autumn leaves clothe its nakedness. And so it is, I can stand where my forbears stood in the dawn of colonial days and see what they saw. The dead are still dead, but the dead past returns to me.

Who shall. say when the waters of this little brook began to babble? This small stream, hidden by trees that no man ever saw, may have been seeking an outlet to the river, when life that long since outgrew its usefulness wandered along it and slaked its thirst in silent, unsunned pools. Nature can take us by the hand and lead us backward as well as forward, if she will, and so she did, to-day. I saw this trifling wrinkle in the world's face, a wooded valley, tortuous, long and deep, and as Nature would have it, save the mud-plastered stretch that should have been green. Man's necessities work havoc with Nature's purposes. She accepts the change for a time, but occasionally shows her resentment, as when the storm washed away the dam. She had accepted it here and the pond was very pretty, but I could never forget that it was a 
pond. It contradicted the outlook, as if water was running uphill. "How pretty!" exclaims the casual passer-by. How grand the valley with its brook, is my impression. A slab of polished wood is very attractive, I admit, but I love better the tree as it stands. I have a few friends, and trust I appreciate them; but I should not care to have a piece of one of them, however skillfully preserved, standing about as bric-a-brac. A submerged section of a valley is not to be preferred to the handiwork of $\mathrm{Na}$ ture. What Nature herself submerges is beautiful and fitting, but mill-ponds and Nature are ever at war, and I march, as a private, in the latter's company.

The empty mill-pond sets one to thinking. It would do so, whatever the conditions of the day, but now it is superb Indian summer and a colored landscape is more intoxicating than one uniformly green. Not all browns are dingy and suggestive of decay. Now, there is no dull procession of sober thought, no serious occupation with life's imperious problems, but all is merriment, laughter, song. The sun shines on us with approving smile; there is invigorating, not depressing, warmth, and wandering warblers 274 


\section{From Pillar to Post}

seeking the Southern woods, tarry in a contented way as if the groal of their journey had been reached. No leaf, to-day, falls like a clod, but floats like a fairy in the golden air and touches earth at last, so lightly, that we look for it to rise again and seek its one-time summer home in the tree-top. Nature herself is a poet beyond compare these dreamy days. Why should I call to mind any of life's realities? The grinning crew are awaiting me when I face the world again, while here is not the world but the valley of a dead past, and I can walk and think of what I will, even to imagining myself an English settler, a subject of Queen Anne;anything at all but the plagues of my existence, the grim fact that this is 190 - and not two centuries ago.

Nature loves to spin us around in a sudden fashion that is startling but wholesome, if not pleasant; and out of the airy realm of fancy face us toward a stern fact. It was so with me to-day. I saw a large portion of a tree encased in clay. Not silicified, but woody enough to burn, when dry, and yet it has been in this bed of clay for, who can tell, how many centuries. If the clay is cretaceous, a cautious geologist 


\section{The Rambles of an Idler}

will say for more than a million years! How easy to write these words: how difficult to get any real conception of what they mean! This prostrate tree-trunk did not grow alone; it was one of many; of a forest that flourished before men were, and when the lord of creation was a gigantic lizard. "The dust we tread upon was once alive." No one questions this, but how few consider what one-time living worlds are beneath us all the while! A forest full of lizards, and streams with sharks, and shallow bays with creatures grim beyond words. We do not let our minds out when we pick up a fossil; do not conjure up a picture of its day, its habitat and surroundings; its associates and the daily routine of its existence. I have heard the remark: Who cares for what happened a million years ago? The fool, forever rooting in the filth of the present, hoping to smell out a dollar, does not, that is certain.

An empty mill-pond, a.y! and an empty head who sees nothing in it but space that should be filled with water. The world is nowhere empty. The void we deplore is really 'twixt our scalp and eye-balls, when we chatter in such fashion. The whole story of this empty mill-pond will $276^{\circ}$ 


\section{From Pillar to Post}

never be told. Life is too short. Its opening chapter deals with time so distant we cannot conceive it, and not a day has since been lost. Nature's diary is no petty note-book. Man figures no more largely in it than a rock or a tree.

Again an autumn day to be remembered. Some small words are to many a large thought like the trigger to the gun; speak the one or pull the other and great results follow. An autumn day! He must be stolid indeed who is not moved by the mere mention of it. A day, this, that comes all too seldom; a mellow day, like to a perfected apple, as fair to the touch as to the taste; and thus it happened, in my walk, that I was stayed by the ruins of an old spring-house. It is rare good luck to have an autumnal and atavic day in one. This is what remains of a spring-house my great-grandfather built. Who lined the spring with pebbles, whether red man or white, I do not know, but Indians knew these sparkling waters well. The ashes of their camp-fires are not yet scattered to the winds. Potsherds are still abundant in the surrounding soil. But these people have had their day and may joy go with them; 


\section{The Rambles of an Idler}

I am concerned with those who followed. They were fine days, I fancy, when folk lived just a little nearer Nature. The cool butter and the sweet milk that came from the spring-house, where never a breath of summer entered, were better, I am sure, than the frozen fat and formaldehyded milk of to-day. Artificiality has its place, and ice in summer is a blessing; but there is no need to pity those who had a springhouse near the kitchen. Food then was wholesome, and no question concerning it could arise.

Looking over an old letter, I find a description of a home-coming dinner. Served now, some people might rebel. No fancy foreign dishes, nor even ice-cream ; but there was wholesome beef, fresh-killed chicken, home-grown vegetables with all the sweetness Nature had packed into them, sugar-preserved fruit and syllabub; and what needed to be cool was brought straight from the spring-house with the coolness of a bubbling spring and an untainted atmosphere about it. How could our forbears have done without modern conveniences? is often asked. Well, they did, but that which fore-ran what we now have met every real need. Our grandfathers never went hungry, 
and did not know, as we do, about loss of appetite. Nearer to Nature: that is the whole secret.

Sitting on the trunk of a prostrate tree, an old chestnut that once shaded half this pretty spot, I recalled this day, a century ago. Some of the nearby trees were then standing. The outlook has suffered no serious change. Even the stone-paved pathway from the kitchen door is not yet gone. The heavy air dulls the sounds of the busy to-day and the more leisured yesterday of 1804 comes back, for leisure entered largely into existence then. Not idleness, but unperturbed occupation. Those were days of healthy, not fevered, activity; and, I notice, they built their houses and bridges of stone, and they still stand. Those were days of oak, not hemlock, and the spring-house before me would not be a ruin, had not man deliberately destroyed it in part.

Deliberate days, then. Here is an extract from an old letter: "How extremely disappointed were we this morning in not receiving a letter. So anxious were we to hear. Mother arose very early and went up to Trenton to breakfast. We were informed the packet from the Springs was to be in last night. We have 
concluded it was not neglect of thine in not writing, but that of the postmaster in not sending any letters to Newark before the mail there closed, which we hear is often the case." Postmasters took the world easy then, even if it did disturb others somewhat, on rare occasions. What a rumpus is kicked up, now, if a letter is delayed! Surely we do things better in these advanced days. No one gets up before breakfast to get a letter. It is left at his door. All true, but here is another letter, from which I extract: "There was wild confusion in the middle of the night on fourth day last, the dogs barking furiously, and then we had Washington -not the General-shouting like mad. We were all quickly astir, and father and brother John were out, half-clad, in response to Washington's call for help. I got there, too, somehow, and such a sight! A wild-cat had squeezed its way into the spring-house and the dog kept it from escaping. Such a sight, I say, but funniest of all, Washington had put one foot entirely through a milk pan, and, it being pretty dark, he was kicking at it with his free foot as frantically as if the cat itself was fastened to his leg. Poor Nero suffered from the beast's 


\section{From Pillar to Post}

claws, and father thinks he should be killed, but we all say No, and are nursing him by turns. $\mathrm{He}$ is a queer-looking dog, in bandages, but very patient, and I am sure quite understands what it all means. I came near forgetting to say that the cat escaped and we are afraid now to go, after dark, over to neighbor Pearson's."

A wildcat in the spring-house! Here we are getting close to Nature, and who can say that country-life since then has not suffered! We have refrigerators now, it is true, and Tabby puts her nose in, it may be, if the door is left ajar, but a wildcat in the spring-house! We of to-day are all too late. We missed much by not reaching the earth earlier.

Here is an extract from still another letter, written ninety years ago: "Jane came rushing into the kitchen, a little after dark, quite out of breath and declaring between gasps that she had seen a ghost. Father laughed and said he would like to see it, but Jane would not go out, so father and I went to the spot as she directed us. I tell thee beforehand I never want to see a real live ghost. What father and I saw was quite sufficient. The moon was shining through the misty air and a great white object moved to 
and fro directly across the narrow path between the great oaks near the stile. I confess to shuddering when I saw it, and father did not walk bravely, to say the least. Then we came to a stand when a great owl hooted. I wanted to turn back, but father said No, and yet did not move forward. What would have happened I do not know, but just then the moon shone out more brightly and we saw that it was a great cobweb covered with dew. Then father chuckled to himself and we came back to the house. I am glad it proved no 'stubborn unlaid ghost,' as Milton has it, but I fear Jane can never be convinced."

It is never a serious task to find a Garden of Eden. Only our unreasonableness blinds us when the search is made. No flaming swords warn us to keep away from Earth's prettiest spots, and if Adam had a nobler tree than my meadow hickory under which to nest, or a fairer outlook than the long line of wooded bluff confronting me, then he had more than he could appropriate. There was no richer green then than Nature now provides, nor any more graceful or intricate an arrangement of bloom and 
foliage. The line of beauty is older than the world. Doubtless there was more beauty in Adam's garden than in my own, but not greater beauty. We have perfection at hand when we can discover no blemish, and so, this blessed October day, the meadow is a Garden of Eden, and I have no regret that the site of the older one has been long forgotten. The cursing of the grounds beyond its confines was local, not circumambient. Were there better things here, man would have to be better to enjoy them. My meadow hickory meets all my needs; within the range of its refreshing shade the world is Edenic. I am not troubled because Adam lost his garden. That was so long ago, regret no longer dims the sunshine of the soul; and here I have a garden that calls for no improvement. Content transfigures the desert.

It is not within the range of descriptive power to make plain to another all that goes to the making of a perfect day. What, indeed, is a "perfect day"? The Eskimo would curse roundly at many such as we consider nonpareil. The tropic islander pictures Sheol as a land of ice. Where, I would ask, is the imperfection of any day? The cyclone is an ugly thing to meet 
if we are unprepared; tempests and tornadoes are not children's playthings, but they have their points of interest to a healthy man. Nature is something more than "sweet sixteen," and man should be above forever dangling about this pretty but not thought-stimulating. phase of creation.

There is no lack of the Edenic in the world, and the flaming sword that guarded sacred places has long been sheathed; but there is lack of ability to discover them. Thorns and thistles are as easily handled as gossamer or feathers if we have acquired the art, and it is not the fault of thistles or thorns if we remain ignorant. We are forever protesting against the consequences of our own ignorance, but it would be well to remember that thorns and thistles have been longer on the earth than man, as the rocks testify; and to assert that their purpose is to render our lives miserable is the climax of silliness. I do not know why the truth should be forever suppressed and our vision distorted by the whims of ignorance.

That is a perfect day when we can meet it on equal terms, and that man's condition approaches to ideal health and strength when the 284 


\section{From Pillar to Post}

beauty of the day's purpose is made plain to him who faces Nature in her most exaggerated moods. The driving rain, the sullen blast, the crashing of branches yielding to the storm, are too full of meaning to be ignored, yet personal comfort usually controls and we are blind to all that happens about us. Huddled in our dens, we scarcely peep out of the holes until some confiding thrush announces that the skies are clear. Every day is perfect of its kind, and those people are lacking who are equal to only one sort of day. We can have our Eden anywhere, and we are not to be despoiled unless we elect to permit it. Demonstrate your unfitness, and the penalty of violating the laws of common-sense will be your portion. Perhaps Adam deserved to be turned out,-it is an open question,- - but he need not have been plagued with thorns and thistles had he been what man is capable of being.

The advantage of the Eden of to-day is that all restrictions on our curiosity are removed. We can taste of every fruit and are urged to do so. Our limitations of knowledge are due to our laziness. We are treated more fairly than Adam the first. 
I well remember one hot August day when all the world seemed bathed in molten brass, a day suggestive of cosmical catastrophe, of sailing in the wake of a consuming planet, when a universal shooting up of flames would not surprise us; and here, at such a time, I found a cool, sweet spot where the shaded brook laughed as it hurried towards the outside world. It was a trifle of the temperate clime enclosed by the tropics. I found it, tarried, and was happy. Moral: Look for an Eden wherever you are, and the chances are you will find it. It is only a hopeless quest when you are persistently unreasonable, and reject ice when it is not as hard as flint, or scorn a quartz crystal because it is not a diamond. Paste can be very pretty, although but paste. Put it to no severer test than the eye brings to bear upon it, and the sense of vision will be pleased. Everywhere the world is graded from diamonds to paste, and why reject the latter and be miserable? Paste has its part to play, and had better be allowed to play it well than for us to rebel because it is not a diamond. As if the hillock should hide itself because there is a mountain in the distance.

Eden is bounded only by the limits of the 286 
sphere. Adam lacked wisdom so far as not to consider fully the advantage at hand before seeking greater ones beyond his reach. Content our weapon, we may laugh at flaming swords. Eden is ours if we elect to move forward and possess it.

If all was good and fair we met,

This earth had been the Paradise.

I should keenly regret this sentiment being accepted universally as good philosophy. I do not think it is philosophical at all. What is not good as we view it is so because we view it wrongly. The fault is in ourselves. What is truly ugly? Our imperfect vision makes many a straight line crooked, and twists to unseemly angles the curve of beauty. All ugliness is in ourselves. I love the earth too dearly to hear it maligned.

If all were good, goodness would cease to be. It is a comparative condition, and rational enjoyment consists in appreciating that what is might be less, as we would have it. Had we no recollection of sour, unripe fruit, we would lose the delight of eating fruit that is perfect. Just in proportion as we take the affairs of life as 287 
matters of course, do we cease to realize their goodness.

This is equally true of what we see. Nothing is easier than to defend ugliness successfully. Let me bring this home in a painfully direct way. Does loveliness depart as the cruel years hurry by? Where is that charming face which captured the heart when youth was at the helm Time has writ wrinkles where the brow was once as polished marble, but does the lover cease to be a lover because of it? Has the charm fled? Does the word "ugly" even enter into the mind? Such things have been, I admit, but the imperfection of man in such a case is abnormal. All else is perfect or marvelously near it. Man alone is yet in a formative stage, and this is his sole excuse for the ugliness that is in him and found nowhere else. Falling short of what he ought to be, he cries out "ugly" at whatever he fails to realize in its full significance. "Ugly" is but the echo of man's deficiency.

The rotting carcass fills us with disgust. All our senses are sickened when we face such an object; but let chemistry come to our aid, and, while we may still be desirous of avoiding the 288 
process, what transpires is the very essence of poetry, the reincarnation of what now cumbers the ground. A rotting carcass! How the very mention of it moves us to shudder! But in due time that body will reappear as the vigorous tree, the beautiful flower, the green grass; no longer an entity, but its parent dust mingled with the dust of the earth, the mother of all things, that now gives it a new birth, as beautiful as before. Consider the purpose, also the ultimate result. The painter's palette wearies the eye; the tubes with their pigments that are slowly vomited forth are sadly repelling to a sensitive soul: be patient. That same soul will be enraptured when the canvas is ready for his eye.

A certain Dr. John Lightfoot, very learned in his day, so it is said, decided and announced that Eden and the rest of the world were created в.c. 4004, October 23, at nine A.M. This then, is the five thousand nine hundred and ninth anniversary, and nowhere can it be better celebrated than at the foot of the meadow hickory. Why? Because I am satisfied. I am celebrating the day. For music, I have the songs of many birds; for applause, the cawing 289 


\section{The Rambles of an Idler}

of crows; as to speech-making, that is my affair. To my neighbor this date has no special significance, which is fortunate, for there is nothing in this world that is not ruined by a crowd, not even an anniversary.

Better, on such a day as this, to be audience than actor. There is something in the air suggestive of a holiday. The regular course of affairs appears to have been set aside. Birds whistle with the animation of children at a picnic. It is not a day to listen to anyone who discourses on physies or mentions ozone. If one man can bring himself to believe this is the day and date of creation, why should not an. other play the fool and keep up the farce?

Seated at the foot of this old hickory, I call the place Eden because at this moment the sky is blue. This alone is cause for thankfulness. There are masses of white clouds anchored in the east, castles, hills, meadows, and strange shapes of an airy world, white as new-fallen snow and tinged with pink, - a picture that can never tire, fancy weaving a new story of it alf when next we look. 'Twixt cloudland and the earth sail, in wide-reaching circles, red-tailed hawks. Birds, these, prosy enough, nearer at 290 
hand, but each a stanza, now, in the poem: October. Still nearer, the bluebird, telling over the joys of long summer days or carrying the message of the frosty air, making merry over the past, finding nothing but happiness in the present. The song of the bluebird straightens many a crooked line as we listen. All the snakes in the meadow may hiss at once, but the bluebird's voice will be heard above them. By so much my Eden of to-day is in advance of the Eden of old.

The tall growths of the weedy marsh are stately still. They have grown gray, and many a seared blossom is a sad reminder of departed strength, but the dignity of age remains. The reed, the mallow, and the rank wild rice have the art of growing old gracefully, something too often neglected among mankind. Clustered in the marsh, they were but the homes of summer birds when I last saw them, but now they invite to individual inspection and stand the test of my exacting mood. The marsh-wrens have departed and the king-rail and little bittern no longer skulk in the weedy wilderness, but I have no feeling as of one wandering through a deserted house. The guests are gone, 


\section{The Rambles of an Idler}

but the host remains. Though bent with the weight of days, many a proud plant is excellent company. Suggestive friends are as desirable as communicative ones. Who has not known the latter to say too much? The marsh is not "open" only for a season. The summer guests are gone, but as noble a company of autumn friends have come or are coming. How, then, can all things Edenic be ever wanting? My friends, the birds, are never absent long. Sitting by the marsh, I join with the plants and play the part of host. Though its leaves are falling, the noble hickory is no less a tree, and brown meadows are as firm and upholding as when grass was green. Birds are singing, too. The lark, the redwing, and the crested tit announce the goodness of all they see, but nowhere do we find evidence of a world begun. All points to maturity. The present Eden never flashed into being in October.

Hidden from the truth-telling out-door world by walls of musty tomes, I fancy I can see the learned Dr. Lightfoot delving industriously for the fact that in grotesque shape finally made him ridiculous. Let us turn from so sad a sight and have the meadows again before us. Such 
an outlook never leads us astray. Eden in October, but not a new-born one. An autumnal Elysium here, now, this twenty-third of October, but no trace of the beginning of such glory remains. The forest with its crimson banners is a retreating, not an advancing host. What was promised has been accomplished, and this is the theme to-day of all rejoicing. If there be Edens and Edens, not a single one, that being long lost, then grade them as to character only, for their value is the same. There is that Eden created every bright May morning: there is the Eden of an October day.

Paradise was not for a brief space and never to return. The world is a series of short-lived creations. Paradise is daily lost, perhaps; but, if you so desire, it is also, daily, Paradise regained.

Shall I call thee Bird

Or but a wandering voice?

The echo is seldom as distinct as the original sound and not every October day is even suggestive of summer. At its best, the month is something more than imitative. It has characteristics all its own. Quiet enthusiasm, so at293 


\section{The Rambles of an Idler}

tractive to those not young, finds fitting hours in the tempered sunshine. Life is less a mystery. The frost has cleared the air and we see more clearly what the round year means. The yellow leaves point backward, and thought, in October, is prone to travel in that direction. Nature's activity is on the wane. Few are the singing birds, but many the wandering voices in the air. Whatever the time of year, there is a marked difference between forenoon and afternoon. It needs no knowledge of the sun's position to tell the hour. Meridian passed, there is that lessening of activities so suggestive of Nature taking a post-prandial nap. I speak only of clear, sun-lit days, when the few cloud-masses, drifting overhead, pass by unheeded.

This is a perfect day. There is no speck or flaw upon it. He who would search for a blemish is not worthy of the dregs of earth. There is gossamer now, but no cobwebs. The grass glistens; the dead leaves are not dingy, and what beauty they have is not concealed. Whatever is, is best of its kind. It is now October, not May. A ripe day, not a green, maturing 


\section{From Pillar to Post}

one. We have had our roses; now it is the ruddy cheek of the apple. A fair exchange, and we do not return empty handed from a ramble. I remember the beautiful blossom of the oak and am equally pleased with the polished acorn. I recall the frail flowers that could be only looked upon, but many a berry and seed pod now can be handled safely. The sense of touch is gratified. In May we discover beauty; in October we carry it home triumphantly.

Mid-afternoon now, and all things idle. Even the lithe branches of the weeping willow move only in their dreams. The passing breeze disturbs nothing in its path. Quiet prevails; not one distracting sound reaches me, yet there is not absolute silence. As when a long-forgotten song comes back to us, and another day is pictured in the mind, $\mathrm{I}$ hear a few, faint, unconnected notes, a fragment of springtide music. I look in vain for the bird that utters it. Every tree and bush beneath it is alike deserted. I hear a wandering voice.

As deftly as the skilled musician touches the keys of the piano or draws the bow across the 295 
respondent strings, this wandering voice plays upon the heart and opens up the fullness of our lives. The ecstatic minstrelsy of May thrilled youth to the pitch of madness. It was a joy to live in the heyday of the year's energy, but not less so now. Sadness finds no welcome. A wandering voice replaces the singing bird, but the change is not to be regretted. We can picture in the October landscape all the roses of June and be blind, the while, to their investing thorns.

Life is to be measured by its results and not by the energy expended. So with the year. The hurried procession of æstival bloom; the trees and shrubs and annual upstart weeds with endless intricate patterns of green leaves; the grand chorus of the struggle for supremacy, if not existence-the bewildering tumult of the year in its youthful days; of all this we can think now, discussing each separate merit at leisure, and live over again such moments as we choose. It is the fitting employment of such an afternoon as this; thought's harvest hour.

The sudden appearance, momentary stay and abrupt departure of single migrating birds is a 296 


\section{From Pillar to Post}

feature of an October afternoon that is full to the very brim with delightful significance. We find such birds set down in the text books as "stragglers," thus giving as mean an impression as possible, and, worse than that, an incorrect one. Late autumn migrants warrant no such conclusion as their being victims of some mishap. They fly with vigor, hold themselves erect and scan the prospect proud as Lucifer, and, better than all else, whistle a few bars of a merry tune, or warble in lower strain, as their mood directs. Such are these scattered birds when within the range of vision; when not, then the no less suggestive wandering voices in the air.

Assuming that we have been diligent until now and studied Nature since our year's outings commenced, we can now contemplate her as a whole and put by analysis until spring comes again. It is well to make such a change at the proper time. He misses much who can see a diamond only as a form of carbon. The sparkle of the crystal is lost, and our lives need the diamond's play of light and color as much as the body needs food. Sunshine resting on an autumn leaf should not be profaned by math- 


\section{The Rambles of an Idler}

ematical calculations. Life is weighted with plain prose and to spare; grant us, at least, the poetry of one October day.

Within the range of my rambles there are few abrupt changes. I cannot recall any at present. October is not something new, separate and apart, but the summer's afterthought. The last Turk's-cap lily had not fallen before golden rod brightened the dingy weeds along the roadside; that was in August, and now crimson leaves still cling to the maples, and scarlet creeper glows wherever it has found support for its sinuous, tangled growth. Color continues, and what does it matter that it is not the bloom of youth, but the hectic flush prophetic of decay? October is better fitted for considering color, per se, rather than its chemistry. The same is true of what we hear. Specific identification is too serious a subject to be undertaken now. It signifies nothing what bird sings or chirps. We hear a sound that shapes a day dream merely; the bird is forgotten; we dally only with a wandering voice.

So pass the idle hours of an October afternoon. Idle, yet full of significance; so full that 


\section{From Pillar to Post}

we think faster than when' confronted by May's marshalling of facts. The spiritual element that is a reality and demonstrable, stands so prominently in the foreground that the foundation and material fabric are but dimly seen. This is the subtle charm that makes October memorable. It is hard, indeed, to be otherwise than materialistic early in the year; it is more difficult not to be spiritual in autumn. The bird that sang so charmingly in May was, nevertheless, of the earth, earthy ; not so to-day the wandering voice I hear.

The fading light and lengthening shadows mark a change that brings us back to all things as they are. The hum of a million insects fills the air. Activity replaces idleness. The rocks are no longer softened by the golden haze, but are rugged, hard and cold again. The breeze freshens; the falling leaves are hurried to the ground. The change is complete; the world is again to be considered as a fact and not contemplated as a fancy.

The air hints of frost. A white mist, slowly rising from the marsh, loosens the hillocks from 299 
their moorings, and now they are as islands dotting the surface of a new-born lake. The owl is astir; the bat flits silently above the gloom. Activity increases. The cricket grows noisier as night draws near. Again, it is the - busy world. Again, it is the old struggle for gain, rather than the enjoyment of it. But why care? As I retrace my steps, following the old, familiar path, above the rustling of crisp leaves, above the roar of endless hosts of insect life, I hear a wandering voice. 


\section{INDEX}

Abbott's Landing, 1

Accentor, Insistent, 67, 172

Aceidents, 188

Acorns, 234

Adversity, virtue of, 256

Assop, quoted, 260

Age, advance of, 152

Almanacs, 130, 133

Angling, 187

Animal Intelligence, 171, 176

Animals, enemies of, 210

Antipodes, dwellers at, 246

Apples, 198, 227

Apple-tree, 61

Archæologists, 113

Aristotle, 4

Arrow-points, 113, 166, 175

Artificiality, 62

Assunpink Creek, 7

Aster, 233

Atlantic Ocean, 70

Atmosphere, "colonial," 164

Attics, 97, 164

Authors, originality of, 116

Authorship, 122

Azalea, pink, 62, 165, 170

Bacon, quoted, 256

Bats, 98

Bear, 248

Beaver, 248

Beeches, 95, 154, 233

"Three," 85

Bidens, 261
Birds, since 1874, 149

" quarrels among, 183

“ songs of in winter, 149

a young, enemies of, 83

Bittern, great, 80 “ little, 251

Blackberry pie, 106

Bladderwort, 180

Blizzard of 1888, 52

Blue-bird, 52, 102, 135, 142, $149,151,226,271,263$

Bluet, 165, 170, 233

Blue-jay, 135, 225, 237

Bobolink, 263

Bobwhite, 270

Books, modern, 117

Botanists, 114

Bowlders, 233

Bugbears, 122

Bugs, aquatic, 252

Buttercup, 62, 170

Button-bush, 177

Buttons, old, 166

Cabbage, skunk, 68, 130

Calendars, 115, 254

Camp-fires, Indian, 277

Candlesticks, Colonial, 99

Candor, 160, 192

Canton, China, 99

Cardinal, 101, 135, 142, 151

Catbird, 66, 90, 101, 165

Cedar, 6

Cellars, 97 
Chat, 69, 165

Cherry, wild, 105

"s wood, 6

Chestnut, 217

Chickadee, viii, 237

Chipmunk, 250, 253

Cicada, 103

Clamor of Crowds, 136

Claytonia, 233

Clouds, 290

Cobwebs, 34

Colonial dinner, 278

Colonists, English, 216

Columbine, 62

Comets, 4, 82

Common sense, 185

Cone flower, 261

Cram, W. E., quoted, 74

Crane's bill, 170

Creeper, black and white, 172

Cretaceous clay, 275

Cricket, black, 300

$$
\text { " mole, } 106
$$

Crosswicks Creek, 188

Crow-blackbirds, 49

Crows, 124, 127, 135, 252, 263

Crystals, 4

Cuckoo, 108

$$
\text { life of, } 42
$$

Cynthia, 89

Cypripediums, 235

Dandelion, 56, 165

Darkness, disadvantages of, 155

Dewdrops, 268

Dirt, real nature of, 160

Dodder, 261

Dogwood, 139

Druids, 221

Dutch settlers, early, 248
Eagle, bald, 215

Ecclesiastes, 117

Eden: Past and Present, 282

Electricity, 162

Elm, 114, 184, 217 insect foes of, 154

Elysian field, 163

Emerson, quoted, 230, 271

Entomologists, 114

Erebus, 156

Erigeron, 89

Eskimos, 43, 283

Eupatorium, 261

Ferns, 174

Fiddle-heads, 174

Finch, thistle, 104

Fish-hawk, 215

Fish, tree-climbing, 222

Fishes, diurnal, 181 " intelligence of, 181

Flies, 241

Floods, glacial, 261

Flycatcher, great - crested, 103

Flyeatchers, 214

Foot-prints, 249

Forest floor, 231

Forerunners, our, 147

Fortinbras, 81

Fossil wood, 275

"Freshet of '41," 8

Frogs, 80, 137, 146, 237

Frost, 299

Furnishings, household, old, 99

Furniture, old, 4

Garden of Eden, 282 302

Geologists, timidity of, 110 


\section{Index}

Golden rod, 233

Gossamer, 37

Grakles, purple, 49, 252

Grape, 105

Grasshopper, 252

Green-brier, 105

Grosbeak, rose-breasted, 54 $60,164,254$

Gum tree, 217, 266

Hamadryad, 86

Hamlet, 81

Hare, 259

Hawk, scream of, 57

Hawks, 135, 245

Heart's Ease, 146

Heron, green, 84

$$
\text { "6 night, } 80,158
$$

Hickory, 290

Hornbeam, 239

Hornet, nest of, 75

Huckleberries, 235

Humming birds, 174

Hyla, 134

Hylodes, 134

Idea, new, what constitutes, 120

Idleness, $\nabla$

Ill-luck, 255

Inanimate objects, perversity of, 185

Indians, 30, 113, 165, 175, 211, $216,233,248,272,277$

Indian summer, 274 “ relics, 165,175

Indigo finch, 102

Iris, 89

Jack-in-the-pulpit, 170

Jeremiah, 117

Job, 117
Kalm, Peter, quoted, 78

Katy-did, 104, 230

Keats, quoted, 239

King-bird, 102, 263

King-fisher, 179

Leaves, second growth of, 101 Letters, old, quoted, 279

Library, defined, 126

Lightfoot, Dr. John, quoted, 289

Lily, pond, yellow, 180

"turk's cap, 298

" water, 165,245

Linden, 72

Literature, 202

“ Aristotelian, 118

“ Emersonian, 118

" Dantesque, 118

" Darwinian, 118

“ Homeric, 118

“ modern, 118

“ Shakespearean, 118

“ Virgilic, 118

Lobelia, scarlet, 261

Lungwort, purple, 165

Lysimachia, 89

Mallow, 261

Man, enemies of, 210

Maple, 105, 217

March 21, significance of, 142

Mastodon, 232

Maurice River, 2

Mayday, 55, 163

May, wet days in, 63

Meditations, peripatetic, 152

Meeting house, Friends', 96

Memory, grip of, 265

Milfoil, 165, 180 


\section{Index}

Mink, 240

Minnows, 239

Misfortune, excellence of, 204

Montana, 75

Moose, 232

Morning, an Alpine, 41

Moss, 234, 236

Mouse, field, 176, 210

" meadow, 240, 251

" white-footed, 226

“ vesper, 257

Muskrat, 240, 248

Nature, 153

“ number three in, 169

" source of inspiration, 117

" views of, 126

Natural history, trustworthiness of, 212

New Jersey, 64

Night's Plutonian shore, $1: 28$

November, nut-brown, 223

Oak, chestnut-leaved, 222

" Crosswicks', 32

" insect foes of, 154

"white, great size of, 221

Oaks, Under the, 216

Opossum, 226

Oenothera, 89

Originality, an ideal, 269

Oriole, 257

Ornithology, newspaper, 149

Oven-bird, song of, 172

Owls, 80, 157, 197

Ownership, sense of, 244

Oxygen, 162

Ozone, 162

Pan, 246

Paradise, 4, 293
Peewee, wood, 102, 184

Penstemon, 89

Perch, pirate, 181

Persimmon, 217

Pewter plates, 141

Phlox, 89

Pickerel weed, 165

Pike, 211, 245

Plantain, rattlesnake, 235

Plant-life, submerged, 179

Plants, aquatic, 165

Plover, killdee, 135

Pluto, 99

Pope, Alexander, quoted, 243

Poplar, Lombardy, 65

Potsherds, 277

Prayer Book quoted, 204

Pumpkins, 258

Quakers, 31

Queen Anne, 275

Rabbits, disease among, 228

Raccoon, 248

Rail, king, 291

Rain, 161

"bow, 246

Rattlesnake weed, 235

Rats, 98

Raven, 128

Pedstart, 170, 172

Redwing, 53, 263

Reed-bird, 203

Reindeer, 232

Rice, wild, 291

Richelieu, 214

Robins, 102, 135, 142, 149, 151

Rocks, riddle of the, 110

Rose-breasted grosbeak, 54, 60 , 164,254

Rushes, 229 


\section{Index}

Sahara, desert of, 245

Saints' Days, 254

Salamanders, 237

Sandpiper, 252

Self-reliance, 271

Senecio, 89

Shellbark, 225

Shelley, quoted, 89

Shelter, 183

Sheol, 283

Skunk, 226

Sleep, 137

Snake, black, 156 " water, 141

Snakes, 140, 251

Sneeze-weed, 261

"Snow-flakes," 44

Solitude, its merits, 58, 153

Solomon, 117, 121

Sparrow, English, 103, 182 " field, 80 “ song, 101, 135, 149, 151

Sparrows, 28, 252

Spatter-dock, 165

Spice wood, 235, 240

Spiders, 252

Spring, commencement of, 133

" flowers of, 143

" poets, 148

Squirrel, flying, 80

Squirrels, 176, 228, 237

Star of Bethlehem, 165

Strawberry, wild, 169

Sunfish, banded, 178

"common, 178

Sunflower, 261

Sunrise, 190

Swallows, 171

Swedes, 248

Temperature, fall of, 75
Terrapin, rough-backed, 174

Thalictrum, 89

Thoughts, company of one's, 148

Thoreau, quoted, 209, 244

Thrush, 61, 69, 95, 101, 165, 267

Tit, crested, 27, 135

Toad, tree, 105

Toads, intelligence of, 157

Tortoise, 259

Trees, growth of, 71 "s old, 30

Truth, 136 "s sacrifice of, 195

Turtle, snapping, 180

Turtles, 105, 174, 237

Violet, white, 146

Violets, 62, 143, 268

Vireo, red-eyed, 69 “ warbling, 69

“ white-eyed, 102

Voice, a wandering, 293

Walking, 4

Warbler, Blackburnian, 171

“ Canadian, 219

"s summer, 172

Warblers, 164, 172, 226

Weasel, 210, 240 " voice of, 74

Weather bureau, statistics of, 65

Weather wisdom, 137

Web, spider, 241

Wildlife, truthful, 197

Willows, 105 and weather, 69

Windflower, 170

Winter, end of, 130

" wreckage of, 154 


\section{Index}

Woodpecker, golden-winged, Wren, marsh, 80, 291

72

Wren, Carolina, 107, 125, 127,

$131,135,142,219$

Wren, house, 72, 75, 182

Wrens, 101

Yellow-jackets, 245

" throat, Maryland, 172 





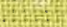

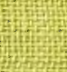

inting 